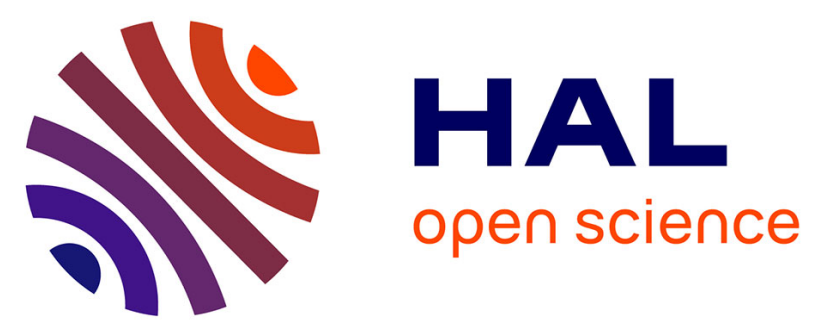

\title{
Crustal recycling and juvenile addition during lithospheric wrenching: The Pontivy-Rostrenen magmatic complex, Armorican Massif (France), Variscan belt
}

Christophe Ballouard, Marc Poujol, Philippe Boulvais, Alexander Zeh

\section{To cite this version:}

Christophe Ballouard, Marc Poujol, Philippe Boulvais, Alexander Zeh. Crustal recycling and juvenile addition during lithospheric wrenching: The Pontivy-Rostrenen magmatic complex, Armorican Massif (France), Variscan belt. Gondwana Research, 2017, 49, pp.222-247. 10.1016/j.gr.2017.06.002 . insu01540445

\section{HAL Id: insu-01540445 \\ https://hal-insu.archives-ouvertes.fr/insu-01540445}

Submitted on 26 Jun 2017

HAL is a multi-disciplinary open access archive for the deposit and dissemination of scientific research documents, whether they are published or not. The documents may come from teaching and research institutions in France or abroad, or from public or private research centers.
L'archive ouverte pluridisciplinaire HAL, est destinée au dépôt et à la diffusion de documents scientifiques de niveau recherche, publiés ou non, émanant des établissements d'enseignement et de recherche français ou étrangers, des laboratoires publics ou privés. 


\section{Accepted Manuscript}

Crustal recycling and juvenile addition during lithospheric wrenching: The Pontivy-Rostrenen magmatic complex, Armorican Massif (France), Variscan belt

C. Ballouard, M. Poujol, P. Boulvais, A. Zeh

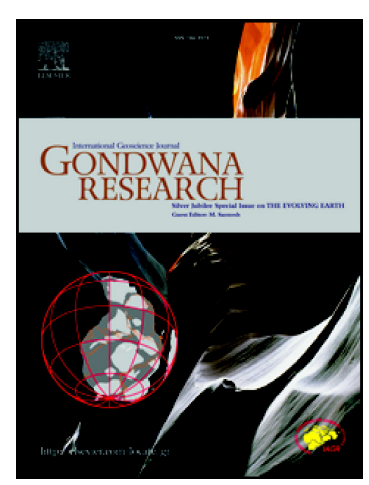

PII:

S1342-937X(16)30197-6

DOI:

doi: $10.1016 /$ j.gr.2017.06.002

Reference:

GR 1824

To appear in:

Received date: $\quad 12$ September 2016

Revised date: $\quad 10$ May 2017

Accepted date: $\quad 6$ June 2017

Please cite this article as: C. Ballouard, M. Poujol, P. Boulvais, A. Zeh, Crustal recycling and juvenile addition during lithospheric wrenching: The Pontivy-Rostrenen magmatic complex, Armorican Massif (France), Variscan belt, (2017), doi: 10.1016/j.gr.2017.06.002

This is a PDF file of an unedited manuscript that has been accepted for publication. As a service to our customers we are providing this early version of the manuscript. The manuscript will undergo copyediting, typesetting, and review of the resulting proof before it is published in its final form. Please note that during the production process errors may be discovered which could affect the content, and all legal disclaimers that apply to the journal pertain. 


\title{
Crustal recycling and juvenile addition during lithospheric
}

\section{wrenching: The Pontivy-Rostrenen magmatic complex,}

\section{Armorican Massif (France), Variscan belt.}

\author{
Ballouard C., b, *, Poujol M. a, Boulvais P.a, Zeh A. ${ }^{\text {c, d }}$
}

${ }^{a} U M R$ CNRS 6118, Géosciences Rennes, OSUR, Université Rennes 1, 35042 Rennes cedex, France

${ }^{b}$ Department of Geology, University of Johannesburg, PO Box 254, Auckland Park 2006, South Africa

*correspondance: christopheballouard@ hotmail.fr

'Institute for Geosciences, Goethe University Frankfurt, Section Mineralogy, Petrology and

Geochemistry, Altenhöferallee 1, D-60438 Frankfurt, Germany

${ }^{\mathrm{d} I n s t i t u t e}$ for Applied Geosciences - Karlsruhe Institute of Technology (KIT), Campus South, Mineralogy and Petrology, Adenauerring 20b, 50.4, D-76131 Karlsruhe, Germany

Keywords: Peraluminous and metaluminous magmatism; strike-slip fault; mantle fertilization; Hercynian belt; South Armorican Shear Zone.

\section{Abstract}

The South Armorican Shear Zone (SASZ), in the French Armorican Variscan belt, is a lithospheric wrench fault that acted during the Late Carboniferous as a transition zone between two distinct domains: a thickened domain to the south affected by extension and crustal magmatism, and a weakly thickened domain to the north subjected to dextral wrenching and crust- and mantle-derived magmatism. The Pontivy-Rostrenen complex is a composite intrusion emplaced along the SASZ. To the south, the complex is made of leucogranites whereas, to the north, monzogranites outcrop together with small intrusions of quartz 
monzodiorite. U-Pb dating of magmatic zircon by LA-ICP-MS reveal that most magmatic rocks were emplaced at ca. $315 \mathrm{Ma}$ (between $316.7 \pm 2.5 \mathrm{Ma}$ and $310.3 \pm 4.7 \mathrm{Ma}$ ), excepted a late leucogranitic intrusion that was emplaced at $304.7 \pm 2.7 \mathrm{Ma}$. The leucogranites $(-4.8<\varepsilon \mathrm{Nd}(\mathrm{T})$ $<2.1$; presence of Archean to Paleozoic inherited zircon) are strongly peraluminous (A/CNK > 1.1) and formed by partial melting of metasediments and peraluminous orthogneisses. The monzogranite $(-4.0<\varepsilon \mathrm{Nd}(\mathrm{T})<-3.2$; scarce Paleozoic inherited zircon) is moderately peraluminous $(1<\mathrm{A} / \mathrm{CNK}<1.3)$ and formed by partial melting of an orthogneiss with a probable metaluminous composition whereas the quartz monzodiorite $(-3.2<\varepsilon \mathrm{Nd}(\mathrm{T})<-2.2$; no inherited zircon) is metaluminous $(0.7<\mathrm{A} / \mathrm{CNK}<1.1)$ and formed by partial melting of a metasomatized lithospheric mantle. The evolution of the magmas was controlled by fractional crystallization, magma mixing and/or peritectic mineral entrainment. At the scale of the Armorican Variscan belt, crustal partial melting, to the south of the SASZ, was triggered by lithospheric thinning and adiabatic decompression during extension. Conversely, to the north, asthenosphere upwelling during strike-slip deformation and subsequent slab tearing, as suggested by tomographic data, induced the melting of both the crust and the mantle fertilized during previous subduction events. This process is likely not exclusive to the Armorican Massif and may be applied to other regions in the Variscan belt, such as Iberia.

\section{Introduction}

Continental-scale strike-slip faults represent major features in orogenic belts as they are able to crosscut the whole lithosphere and to accommodate horizontal displacement for several hundreds of kilometers (Sylvester, 1988; Storti et al., 2003; Vauchez and Tommasi, 2003; Cao and Neubauer, 2016). Transcurrent shear zones commonly mark the boundaries between distinct continental domains, each bearing its own deformation, metamorphic and geomorphologic history. For example, in East Asia and in the Alps, respectively, the Tun-Lu 
fault and Insubric line juxtapose high pressure and/or high temperature metamorphic units with nearly unmetamorphosed rocks (e.g. Gilder et al., 1999; Cao and Neubauer, 2016). In New Zealand, high grade metamorphic rocks exhumed from a depth of $\sim 20 \mathrm{~km}$ outcrop at a high altitude in the hanging wall of the Alpine Fault (e.g. Norris and Cooper, 2000). Lithospheric wrench faults also represent major conduits for hydrothermal fluids (e.g. Sibson, 1987; Pirajno, 2010; Lemarchand et al., 2012) as well as magmas with crustal and/or mantle origins (e.g. Strong and Hanmer, 1981; Hutton and Reavy, 1992; De Saint Blanquat et al., 1998; Cambeses et al., 2016). Partial melting of the crust and/or mantle in strike-slip deformation belts can be enhanced by hydrous fluxing (e.g. Hutton and Reavy, 1992), shear heating (Leloup et al., 1999) and asthenospheric upwelling during a transtensional regime (Rocchi et al., 2003; Barak and Klemperer, 2016; Yang et al., 2016). The shearing and pressure gradient along wrench faults also favor the ascent of magmas to the upper crust (e.g. D'Lemos et al., 1992; De Saint Blanquat et al., 1998) and deformation-driven filter-pressing enhances their differentiation (e.g. Bea et al., 2005).

In the French Armorican Massif (western European Variscan belt), the South Armorican Shear Zone (SASZ) is a major crustal- to lithospheric-scale strike-slip fault which, during the Late Carboniferous, delimitated a crustal domain in extension, thickened during the Variscan orogeny to the south, and a weakly thickened domain submitted to pervasive dextral wrenching and belonging to the external zone of the belt to the north (Berthé et al., 1979; Gapais and Le Corre, 1980; Jégouzo, 1980; Gapais et al., 1993, 2015; Gumiaux et al., 2004a, 2004b). During this period, the Armorican Massif experienced post-collisional magmatism resulting in the emplacement of numerous granitoid intrusions (Carron et al., 1994; Capdevila, 2010) (Fig. 1). In the internal part of the belt, intrusions along but also to the south of the SASZ are almost exclusively peraluminous leucogranites (Bernard-Griffiths et al., 1985; Tartèse and Boulvais, 2010; Ballouard et al, 2015a). In contrast, to the north of the SASZ (in the external domains), 
the granitoids have a more variable composition ranging from metaluminous to peraluminous and display variable degrees of interaction with juvenile mantle-derived magmas (Carron et al., 1994; Capdevila, 2010).

The Pontivy-Rostrenen magmatic complex is a composite intrusion localized in the central part of the Armorican Massif. The granitoids forming this complex were emplaced along or to the north of the SASZ, i.e. at the transition between the internal and external zones of the Armorican Variscan belt. The contribution of mantle-derived magmas in the complex appears to increase from south to north, as is already the case at the scale of the whole Armorican Massif. Thus, this magmatic complex represents a rare opportunity to study crustal recycling and juvenile crust addition in a key zone of the Variscan belt. In this contribution, zircon U-Pb and $\mathrm{Hf}$ analyses are used together with whole-rock major elements, trace elements and radiogenic isotope data to (i) specify the different sources involved in the generation of the magmas, (ii) estimate the timing and duration of their emplacement and (iii) identify the secondary magmatic processes controlling their evolution. These new constraints are integrated within the tectono-magmatic evolution of the western European Variscan belt and provide new information about the magmatic evolution of belts associated with strike-slip tectonics in general.

\section{Geological Context}

\subsection{The Armorican Massif}

The French Armorican Massif belongs to the western European Variscan belt which resulted from the convergence of the Laurussia and Gondwana continents at the end of the Paleozoic (e.g. Ballèvre et al., 2009). The Armorican Massif is divided into three main domains by the North Armorican Shear Zone (NASZ) and South Armorican Shear Zone (SASZ), two dextral crustal- to lithospheric-scale strike-slip faults (Fig. 1) (Judenherc et al., 2003; Gumiaux 
et al., 2004b). The northern domain is mostly made of a Proterozoic basement that belonged to the upper crust during the Variscan orogeny (e.g. Brun et al., 2001). The central domain is mostly composed of Late Proterozoic (Brioverian) to Carboniferous sediments moderately deformed under greenschist facies conditions. Deformation and metamorphism increase from north to south and east to west (e.g. Hanmer et al., 1982; Gumiaux et al., 2004). The deformation is commonly marked by a vertical foliation that bears a lineation that is either sub-horizontal or plunging $5-10^{\circ}$ eastward (Jégouzo, 1980). The southern domain, which belongs to the internal zone of the belt, is characterized by an intense deformation and the presence of high-grade metamorphic rocks represented, from top to bottom, by high pressure-low temperature rocks (HP-LT), micaschists and migmatite-bearing units (Gapais et al., 2015 and references therein; Fig. 1). HP-LT rocks are mostly composed of blueschists (e.g. Ile de Groix in Fig. 1) and metavolcanics which reach a peak P-T condition of 1.4-1.8 GPa, 500-550 ${ }^{\circ} \mathrm{C}$ (Bosse et al., 2002) and $0.8 \mathrm{GPa}, 350-400^{\circ} \mathrm{C}$ (Le Hébel et al., 2002), respectively. Subduction and exhumation of these units relate to early tectonic events, around $360 \mathrm{Ma}$ (Bosse et al., 2005). The lower units are composed of gneisses, granitoids and migmatites with a peak PT condition of $0.8 \mathrm{GPa}, 750$ $800^{\circ} \mathrm{C}$ (Jones and Brown, 1990). From $\sim 320$ to $300 \mathrm{Ma}$ (Zrn and Mnz U-Pb on mylonites; Tartèse et al., 2012), dextral wrenching along the SASZ was synchronous with crustal extension in the southern domain, leading to the formation of core complex cored by migmatites and synkinematic leucogranites (Gapais et al., 2015). During this period, the Armorican Massif experienced significant magmatism which resulted in the emplacement, from south to north overall, of four main granitoid suites (Capdevilla, 2010; Fig. 1):

(i) A magneso-potassic peraluminous suite composed of Ms-Bt leucogranites. Most of these leucogranites were emplaced either along extensional deformation zones in the southern domain, such as the Quiberon (Gapais et al., 1993, 2015), Sarzeau (Turrillot et al., 2009) and Guérande (Ballouard et al., 2015a) leucogranites, or along the SASZ such 
as the Pontivy, Lizio and Questembert leucogranites (Berthé et al., 1979). Among them, the Lizio, Questembert and Guérande leucogranites were dated at 316.4 \pm 5.6 Ma (Zrn U-Pb; Tartèse et al., 2011a), 316.1 +2.9 Ma (Zrn U-Pb; Tartèse et al., 2011b) and 309.7 \pm 1.3 Ma (Zrn and Mnz U-Th-Pb; Ballouard et al., 2015a), respectively. To the northwest, the Saint Renan intrusion emplaced along the NASZ was dated at $316.0 \pm$ 2.0 Ma (Zrn U-Pb, Le Gall et al., 2014). Moderate size intrusions of peraluminous twomica leucogranites are commonly found associated with the granitic intrusions from other suites (Fig. 1).

(ii) A magneso-potassic peraluminous suite composed of $\mathrm{Bt} \pm \mathrm{Crd}$ monzogranites and granites associated with small stocks of quartz monzodiorites. Among these intrusions, the Huelgoat granite was emplaced at $314.8 \pm 2.0 \mathrm{Ma}(\mathrm{U}-\mathrm{Pb} \mathrm{Zrn}$; Ballouard, 2016).

(iii)A magneso-potassic metaluminous suite composed of $\mathrm{Bt} \pm \mathrm{Hbl}$ (hornblende) monzogranites associated with mafic to intermediate rocks ( $\mathrm{Mg}-\mathrm{K} \mathrm{Bt} \pm \mathrm{Hbl}$ granites in Fig. 1). Among these granites, which were emplaced along the NASZ, the Quintin and Plouaret granites were dated at $291 \pm 9 \mathrm{Ma}$ and $329 \pm 5 \mathrm{Ma}$, respectively (whole-rock Rb-Sr, Peucat et al., 1984).

(iv)A ferro-potasic metaluminous suite mostly constituted by $\mathrm{Bt} \pm \mathrm{Hbl}$ monzogranites and syenites associated with mafic to intermediate rocks with a mantle origin (Fe-K Bt \pm Hbl granites in Fig.1). In this suite, the Aber-Ildut monzogranite was emplaced $303.8 \pm$ 0.9 Ma ago (U-Pb Zrn; Caroff et al., 2015) whereas the Ploumanac'h composite intrusion, was emplaced between 308.8 $\pm 2.5 \mathrm{Ma}$ and 301.3 \pm 1.7 Ma (Ballouard et al., 2015b).

\subsection{The Pontivy-Rostrenen magmatic complex}

The Pontivy-Rostrenen magmatic complex (Figs. 1 and 2) is composed of peraluminous leucogranites to the south and peraluminous leucogranites, peraluminous monzogranites and 
metaluminous quartz monzodiorites to the north (Euzen, 1993; Fig. 2a). The peraluminous Langonnet leucogranite crosscuts all the other magmatic rocks (Fig. 2a). Most magmatic rocks present a weak foliation, defined by feldspar megacrysts and mica, broadly parallel to the edges of the intrusions and interpreted as formed during (magmatic) emplacement (Fig. 2). To the south of the complex, the shape of the Pontivy leucogranite is asymmetrical, in consistency with the dextral shearing of the SASZ (Figs. 1 and 2). In its southern side, mylonites occur in 100m wide, N100-110 oriented dextral shear zones (Jégouzo, 1980; Tartèse et al, 2012). The development of C/S structures reveals syn-cooling shearing (Berthé et al., 1979; Gapais, 1989). To the south, leucogranites intrude Late Proterozoic (Brioverian) sediments whereas, to the north, leucogranites, monzogranites and quartz monzodiorites were emplaced in Late Proterozoic and Paleozoic (Ordovician to Lower Carboniferous) sediments. Regional metamorphism in the Late Proterozoic sediments (e.g. Bos et al., 1997) (Fig. 2a) increases from the northeast (chlorite-biotite assemblage) to the southwest (biotite-staurolite assemblage). Contact metamorphism is only visible to the north of the complex (e.g. Bos et al., 1997) and is characterized by the following mineralogical isograds towards the contact with granitoids: andalusite $( \pm$ cordierite $)(+) \rightarrow$ biotite $(+) \rightarrow$ garnet $(+) \rightarrow$ muscovite $(-) \rightarrow$ sillimanite $(+)$.

Gravimetric data (Vigneresse and Brun, 1983; Vigneresse, 1999) (Fig. 2b) indicate that the Pontivy-Rostrenen magmatic complex represents a continuous intrusion with a $6 \mathrm{~km}$ deep main root localized to the north. The thickness of the intrusion varies between 0 and $3 \mathrm{~km}$ and Vigneresse (1999) suggested that these intrusions were emplaced at a depth of around 6-8 km. Previous petro-geochemical and isotopic studies by Bernard-Griffiths et al. (1985) and Euzen (1993) on the Pontivy-Rostrenen magmatic complex suggested that the leucogranites were formed by partial melting of a metasedimentary source. Euzen (1993) also proposed that partial melting of a metasomatized mantle was involved in the formation of the quartz monzodiorites, whereas the monzogranites represent a hybrid magma resulting from the mixing between a 
leucogranitic melt and a mantellic magma. Available geochronological data on this complex are sparse. The Pontivy leucogranite was dated at $344 \pm 8$ Ma using the whole-rock $\mathrm{Rb}-\mathrm{Sr}$ isochron method (Peucat et al., 1979). More recently, an age of $311 \pm 2$ Ma was obtained by Cosca et al. (2011) using the muscovite ${ }^{40} \mathrm{Ar}-{ }^{39} \mathrm{Ar}$ method.

\section{Field and samples description}

Due to the poor outcropping conditions in the area, the sampling was mostly limited to quarries. A total of 25 samples representative of the petrographic heterogeneities were collected in the Pontivy-Rostrenen magmatic complex (Fig. 2). The samples were separated into facies, based on petro-textural and cartographic criteria, as leucogranites (Fig. 3a-b), monzogranites (Fig. 3c-d) and quartz monzodiorites (Fig. 3d) (Table 1).

Strain in the leucogranites increases towards the SASZ from slightly marked magmatic foliations in the north, defined by preferred orientation of undeformed porphyritic feldspar and micas, to $\mathrm{C} / \mathrm{S}$ structures and mylonites in the south (Table 1). The leucogranite samples contain a quartz-K-feldspar-plagioclase-muscovite assemblage with a variable amount of biotite and rare tourmaline (Fig. 4a-b; Table 1). Quartz is mostly anhedral and can display undulose extinction or forms polycrystalline clusters due to intracrystalline deformation. K-feldspar is euhedral to sub-euhedral and commonly appears as megacryst depending on the sub-facies. Plagioclase is generally sub-euhedral, shows polysynthetic twinning and commonly displays myrmekites. Micas are commonly oriented in the foliation. Muscovite is generally euhedral and flake-shaped (Fig. 4a-b) but locally displays a fish-like habit due to deformation. Secondary muscovite (Ms2 in Fig. 4a) commonly occurs as small inclusions in feldspar (sericite) as well as ribbons and as small grains either found in the foliation or around primary micas. Biotite is brown, euhedral to sub-euhedral and is commonly found intergrown with primary muscovite (Ms1 in Fig. 4a). The accessory minerals, commonly hosted by micas, are apatite, zircon, Fe- 
Ti oxide, monazite and rare sulfides. Needles of sillimanite are occasionally found as inclusions in quartz or muscovite. The leucogranites can be divided into three sub-facies:

(1) Porphyritic leucogranite outcrops in the northeastern part of the Pontivy intrusion and in the southern part of the Rostrenen intrusion (Fig. 2). This facies is characterized by the abundance of K-feldspar megacrysts $(1-2 \mathrm{~cm})$ which commonly mark the magmatic foliation (Fig. 3a). The matrix is coarse-grained $(0.2-0.5 \mathrm{~cm})$ and biotite is generally more abundant than muscovite. K-feldspar commonly displays Carlsbad twinning and perthitic exsolutions. Some plagioclase grains are zoned. Schlierens and acid microgranular enclaves are common. The latter were attributed to breaking up of microgranitic dykes also described in this facies (Euzen and Capdevila, 1991).

(2) Equigranular leucogranite represents the most common type (Fig. 2). This facies displays a variable grain size from fine grained $(0.05-0.3 \mathrm{~cm})$ to coarse grained $(0.5-1$ $\mathrm{cm}$ ) and is characterized by the absence (or by a low abundance) of K-feldspar megacrysts $(1-2 \mathrm{~cm})$. The proportion of muscovite and biotite is variable (Fig. 4a-b) and biotite can be absent. In this facies, K-feldspar generally displays tartan twinning characteristic of microcline and perthitic exsolutions. Unfortunately, the poor outcropping conditions did not allow to observe the relationship between this facies and the porphyritic leucogranitic facies.

(3) In map-view, the ellipse-shaped late equigranular leucogranite (i.e. Langonnet leucogranite s.s.) crosscuts the other magmatic facies (Fig. 2) although no contact was observed in the field. This intrusion is mostly composed of medium to coarse grained $(0.2-0.4 \mathrm{~cm})$ equigranular leucogranites characterized by a small proportion of biotite. Yet, a fine grained $(0.1-0.4 \mathrm{~cm})$ weakly porphyritic $(1-2 \mathrm{~cm})$ leucogranite with a higher proportion of biotite than muscovite was also observed. In this facies, K-feldspar 
commonly displays Carlsbad twinning. Secondary muscovitization is generally weak in the samples.

Several quartz, pegmatite and aplite veins crosscut these leucogranites. Pegmatites commonly host a quartz-feldspar-muscovite-(biotite-tourmaline) assemblage. Pegmatite stocksheiders were also described along the western edge of the late equigranular leucogranite, whereas greisenization locally affects both the more evolved term of the equigranular leucogranite and the late equigranular leucogranite (Euzen, 1993; Bos et al., 1997). Chloritization commonly affects biotite (Table 1) and chlorite commonly hosts Fe-Ti oxides.

The monzogranites (i.e. the Rostrenen granite s.s.) outcrop in the northern part of the Rostrenen intrusion (Fig. 2; Fig. 3c). This facies is generally highly porphyritic and K-feldspar megacrysts can reach $15 \mathrm{~cm}$ in length. The matrix $(0.1-0.4 \mathrm{~cm})$ contains a quartz-plagioclasebiotite assemblage together with rare muscovite (Fig. 4c) and cordierite. Quartz is generally anhedral. K-feldspar is generally euhedral and perthitic. Plagioclase is also generally euhedral and is commonly zoned. Biotite is brown and generally sub-euhedral. Muscovite is rare and generally occurs as inclusions in biotite and K-feldspar crystals (Fig. 4c). Cordierite was not observed in our samples but was described by Euzen (1993) as euhedral pinitized crystals that are almost completely replaced by an association of green biotite + muscovite. Apatite, zircon and Fe-Ti oxide are the most common accessory minerals and generally occur as inclusions in biotite. Mafic enclaves with a quartz-monzodiorite composition commonly occur (Euzen, 1993; Fig. 3c). Biotite can be slightly chloritized. The structural relationship between the leucogranites and monzogranite could not be observed in the field.

The quartz monzodiorite facies appears as small stocks (a few square kilometers on the map) mostly in the eastern part of the monzogranitic intrusion. The most important stock occurs near Plélauff, whereas a smaller body occurs in the equigranular leucogranite (Fig. 2). This 
facies is fine- to medium-grained $(0.05-0.4 \mathrm{~cm})$ and generally contains quartz-plagioclase- $\mathrm{K}$ feldspar-biotite-amphibole ( \pm clinopyroxene). Quartz is anhedral and locally forms ocellar textures with amphiboles (Fig. 4d) or clinopyroxenes. Plagioclase is euhedral to sub-euhedral, can display mirmekites and light sericitisation. The K-feldspar abundance is lower than $10 \%$ and commonly displays tartan twinning characteristic of microclines. Biotite is brown to green and euhedral to sub-euhedral. Amphibole is pale green, generally anhedral and commonly forms clusters of crystals together with biotite. Clinopyroxene is rare and appears as subeuhedral, partly resorbed crystals. The most common accessory minerals are apatite, titanite, zircon, Fe-Ti oxide and sulfide. A weak chloritization of biotite is occasionally observed (Table 1). Mingling features are visible at the contact between the monzogranite and quartzmonzodiorite, and $\mathrm{K}$ feldspar megacrysts from the monzogranite are commonly found as xenoliths inside the quartz-monzodiorite (Fig. 3d).

\section{Analytical techniques}

\subsection{Mineral chemistry}

The mineral compositions were measured using a Cameca SX-100 electron microprobe at IFREMER, Plouzané, France. The operating conditions were a $15 \mathrm{kV}$ acceleration voltage, a beam current of $20 \mathrm{nA}$ and a beam diameter of $1 \mu \mathrm{m}$. The counting times were approximately 10 s. Standards were Standards were natural albite $(\mathrm{Na}, \mathrm{Si})$, orthoclase $(\mathrm{K})$, corundum $(\mathrm{Al})$, wollastonite $(\mathrm{Ca})$, forsterite $(\mathrm{Mg}), \mathrm{MnTiO}_{3}(\mathrm{Mn}, \mathrm{Ti})$, andradite $(\mathrm{Fe})$.

\subsection{Major and trace whole-rock element analyses}

Large samples (5 to $10 \mathrm{~kg}$ ) were crushed in the Geosciences Rennes Laboratory following a standard protocol to obtain adequate powder fractions using agate mortars. Chemical analyses were performed by the Service d'Analyse des Roches et des Minéraux (SARM; CRPG-CNRS, 
Nancy, France) using a ICP-AES for the major elements and a ICP-MS for the trace elements following the techniques described in Carignan et al. (2001).

\subsection{Whole-rock isotopic analyses}

$\mathrm{Sm}-\mathrm{Nd}$ and $\mathrm{Sr}$ isotope analyses were carried out on whole-rock samples in the Geosciences Rennes Laboratory using a 7 collectors Finnigan MAT-262 mass spectrometer. The samples

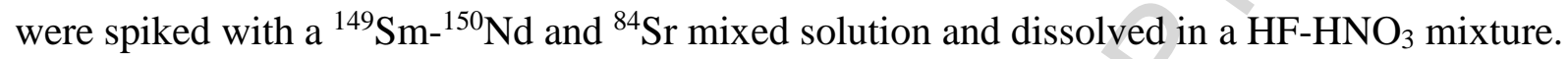
They were then dried and taken up with concentrated $\mathrm{HCl}$. In each analytical session, the unknowns were analyzed together with the Ames Nd-1 Nd or NBS-987 Sr standards which, during the course of this study, yielded an average of $0.511969( \pm 5)$ and $0.710263( \pm 10)$ respectively. All of the analyses of the unknowns were adjusted to the long-term ${ }^{143} \mathrm{Nd} /{ }^{144} \mathrm{Nd}$ value of 0.511963 for Ames Nd-1 and the reported ${ }^{87} \mathrm{Sr} /{ }^{86} \mathrm{Sr}$ values were normalized to the reference value of 0.710250 for NBS-987. The mass fractionation was monitored and corrected using ${ }^{146} \mathrm{Nd} /{ }^{144} \mathrm{Nd}=0.7219$ and ${ }^{88} \mathrm{Sr} /{ }^{86} \mathrm{Sr}=8.3752$. The procedural blank analyses yielded values of $400 \mathrm{pg}$ for $\mathrm{Sr}$ and $50 \mathrm{pg}$ for $\mathrm{Nd}$ and were therefore considered as negligible.

\subsection{Zircon U-Pb and Hf analyses}

A classic mineral separation procedure was applied to concentrate the zircon grains suitable for $\mathrm{U}-\mathrm{Pb}$ dating using the facilities available at Geosciences Rennes (Ballouard et al., 2015). Zircon grains were imaged either by cathodoluminescence (CL) using a Reliotron CL system equipped with a digital color camera available in the Geosciences Rennes Laboratory or by back-scattered electron imaging using a JEOL JSM $7100 \mathrm{~F}$ scanning electron microscope at the Centre de Microscopie Electronique à Balayage et MicroAnalyse (CMEBA; University of Rennes 1).

The U-Th-Pb geochronology of zircon was conducted by in-situ laser ablation inductively coupled plasma mass spectrometry (LA-ICPMS) at Geosciences Rennes using a ESI 
NWR193UC excimer laser coupled to a quadripole Agilent 7700x ICP-MS equipped with a dual pumping system to enhance the sensitivity. The methodology used to perform the analyses can be found in Ballouard et al. (2015) and in Supplementary file 1. All errors given in Supplementary file 2 are listed at $1 \sigma$, but where data are combined to calculate concordia dates, using the Isoplot/Ex software (Ludwig, 2001), the final results are provided with $2 \sigma$ confidence limits. Only the analyses with a degree of concordance between 90 and $110 \%$ are reported in Supplementary file 2.

Hafnium (Hf) isotope analyses were performed at Goethe-University Frankfurt with a Thermo-Finnigan NEPTUNE multicollector ICP-MS coupled to a Resolution M-50 (Resonetics) $193 \mathrm{~nm} \mathrm{ArF} \mathrm{excimer} \mathrm{laser} \mathrm{(ComPexPro} \mathrm{102F,} \mathrm{Coherent),} \mathrm{using} \mathrm{the} \mathrm{procedure}$ outlined in detail in Gerdes and Zeh $(2006,2009)$ and summarized in Supplementary file 1 . The epsilon Hf values $[\varepsilon \mathrm{EH}(\mathrm{t})]$ were calculated using the chondritic uniform reservoir (CHUR) as recommended by Bouvier et al. $\left(2008 ;{ }^{176} \mathrm{Lu} /{ }^{177} \mathrm{Hf}=0.0336\right.$ and $\left.{ }^{176} \mathrm{Hf} /{ }^{177} \mathrm{Hf}=0.282785\right)$ and a decay constant of $1.867 .10^{-11} \mathrm{yr}^{-1}$ (Scherer et al., 2001; Söderlund et al., 2004). The initial ${ }^{176} \mathrm{Hf} /{ }^{177} \mathrm{Hf}_{\mathrm{t}}$ and $\varepsilon \mathrm{Hf}(\mathrm{t})$ values were calculated using intrusion ages for magmatic grains. For inherited zircon grains (with a degree of concordance between 90 and $110 \%$ ), ${ }^{206} \mathrm{~Pb} /{ }^{238} \mathrm{U}$ ages were used for zircon with ${ }^{206} \mathrm{~Pb} /{ }^{207} \mathrm{~Pb}$ ages $<1.0 \mathrm{Ga}$, and ${ }^{206} \mathrm{~Pb} /{ }^{207} \mathrm{~Pb}$ ages for zircon with ${ }^{206} \mathrm{~Pb} /{ }^{207} \mathrm{~Pb}$ ages $>1.0 \mathrm{Ga}$.

\section{Mineral composition}

Seven samples, including one porphyritic leucogranite (PONT-1), four equigranular leucogranites (PONT-10-14-15-26), one late equigranular leucogranite (PONT-21), one monzogranite (PONT-22) and one quartz monzodiorite (PONT-7) were selected for the chemical analysis of feldspar, amphibole, biotite and muscovite. Average mineral chemical compositions are provided in Supplementary file 4. 


\subsection{Feldspar}

The chemical composition of plagioclase displays a well-defined trend in the Ab-An-Or ternary diagram (Fig. 5a) and the average anorthite content of the plagioclase decreases from the quartz monzodiorite ( $\%$ An $=42.2$; mostly andesine $)$, monzogranite $(\%$ An $=27.5$; oligoclase), porphyritic leucogranite ( $\% \mathrm{An}=9.3$; albite-oligoclase $)$, equigranular leucogranites $(\% \mathrm{An}=2.8$; albite $)$ to the late equigranular leucogranite $(\% \mathrm{An}=0.3$; albite $)$. In contrast, the average orthoclase content of K-feldspar is nearly constant and varies from \% Or $=91.1$ in the monzogranite to $\%$ Or $=92.6$ in the leucogranites .

\subsection{Amphibole and biotite}

The amphibole from the quartz monzodiorite is a calcic amphibole $[(\mathrm{Ca}+\mathrm{Na})>1.34]$ with a relatively elevated magnesium content $\left[\mathrm{Mg} /\left(\mathrm{Mg}+\mathrm{Fe}^{2+}\right)>0.5\right]$. Its composition varies mostly from actinolite-hornblende to actinolite (Leake, 1978).

In the $\mathrm{Al}_{\text {tot }}$ versus $\mathrm{Mg}$ diagram (Nachit et al., 1985) (Fig. 5b), the compositions of the biotite found in the leucogranites and monzogranite $\left(\mathrm{Al}_{\text {tot }}>3.38\right)$ plot in the field of the peraluminous granites whereas the biotite compositions from the quartz monzodiorite (average $\mathrm{Al}_{\text {tot }}=2.69$ ) mostly fall in the cal-alkaline field. The average $\mathrm{X}_{\mathrm{Mg}}$ ranges from 0.35 to 0.33 in the leucogranites whereas the average $\mathrm{X}_{\mathrm{Mg}}$ is 0.41 in the monzogranite and 0.46 in the quartz monzodiorite.

\subsection{Muscovite}

In the monzogranite (PONT-22), the compositions of the rare and small muscovite crystals systematically plot in the primary field defined by Miller et al. (1981) (Fig. 5c). In the late equigranular leucogranite sample (PONT-21), the muscovite flakes display a concentric zonation on the Ti distribution maps but all of the analyses also fall in the primary muscovite 
field (Fig. 5c). Regarding the other leucogranite samples, most of the analyses performed on muscovite grains from the porphyritic leucogranite (PONT-1; Bt $>$ Ms) fall in the primary muscovite field whereas for the equigranular leucogranites, the affinity for secondary compositions tends to increase from PONT-26 (Ms = Bt), PONT-15 (Ms > Bt), PONT-10 (Ms $>\mathrm{Bt}$ ) to PONT-14 (Ms) (Fig. 5c). In the PONT-10 and PONT-14 samples, the muscovite flakes commonly display cores and rims with distinct Ti contents (Fig. 5c). The cores generally have high Ti contents and plot in the primary field whereas the rims are depleted in Ti, enriched in $\mathrm{Mg}-\mathrm{Fe}$ and plot in the secondary field. In the leucogranites, small muscovite grains that crystallized in the foliation planes generally plot in the secondary muscovite field and are characterized by elevated $\mathrm{Mg}$ contents.

\section{Whole-rock composition}

The chemical composition of the twenty-five whole-rock granitic samples from the PontivyRostrenen complex collected for this study are reported in Table 2.

\subsection{Major elements}

In the A/NK versus A/CNK diagram (Shand, 1943) (Fig. 6a), both monzogranites and leucogranites plot in the peraluminous field characteristic of crustal granites. The leucogranites are highly peraluminous (A/CNK in the range $1.18-1.47)$ whereas the monzogranites are moderately peraluminous (A/CNK in the range $1.03-1.30)$. The quartz monzodiorite samples fall in the metaluminous field, except for two peraluminous samples, and have A/CNK values in the 0.69-1.10 range. In the Q-P diagram (Debon et Le Fort, 1988) (Fig. 6b), the leucogranites mostly fall in the granite field, the monzogranites in the adamellite (monzogranite) field and the quartz monzodiorite samples in the field characteristic of quartz monzodiorites and quartz monzonites. In the Q-P (Fig. 6b) and A-B (Fig. 6c) diagrams, the leucogranites have a composition similar to that of the melts produced during partial melting experiments of both 
sedimentary and peraluminous igneous rocks. Numerous monzogranite samples display a composition similar to the melts produced during the experimental partial melting of metaluminous igneous rocks in the A-B diagram (Fig. 6c). Finally, the quartz monzodiorite samples have a composition similar to that of the melts produced during the experimental partial melting of phlogopite- \pm amphibole-bearing peridotites (Fig. 6b-c). In Figure 6, the monzogranites plot in an intermediate position between the leucogranites and quartz monzodiorites. In the AFM diagram (Fig. 6d), the quartz monzodiorite samples fall in the calcalkaline field, in good agreement with their biotite compositions (Fig. 5b).

In the Harker diagrams (Fig. 7a), the monzogranite $\left(\mathrm{SiO}_{2}=55.0-60.1 \mathrm{wt} . \%\right)$ and quartz monzodiorite $\left(\mathrm{SiO}_{2}=64.7-71.5\right.$ wt.\% $)$ samples generally define continuous evolution trends but with more scattering for the quartz monzodiorite samples. $\mathrm{CaO}, \mathrm{Al}_{2} \mathrm{O}_{3}$ and the sum $\mathrm{Fe}_{2} \mathrm{O}_{3}$ $+\mathrm{MgO}+\mathrm{TiO}_{2}$ correlate negatively with $\mathrm{SiO}_{2}$ whereas $\mathrm{K}_{2} \mathrm{O}$ and $\mathrm{Na}_{2} \mathrm{O}$ are nearly constant or correlate positively with $\mathrm{SiO}_{2}$. Regarding the leucogranite samples $\left(\mathrm{SiO}_{2}=69.5-74.9\right.$ wt.\%; Fig. 7b), $\mathrm{CaO}, \mathrm{K}_{2} \mathrm{O}$, the sum $\mathrm{Fe}_{2} \mathrm{O}_{3}+\mathrm{MgO}+\mathrm{TiO}_{2}$ and $\mathrm{Al}_{2} \mathrm{O}_{3}$ are negatively correlated with $\mathrm{SiO}_{2}$ whereas $\mathrm{Na}_{2} \mathrm{O}$ is positively correlated with $\mathrm{SiO}_{2}$, despite a non-negligible scattering. Among the leucogranites, the equigranular leucogranites display the larger compositional range $\left(\mathrm{SiO}_{2}=70.0-74.6\right.$ wt.\% $)$ whereas the porphyritic leucogranites display the most primitive compositions $\left(\mathrm{SiO}_{2}=69.5-73.1\right.$ wt.\% $)$. The late equigranular leucogranite samples $\left(\mathrm{SiO}_{2}=\right.$ $72.3-74.9$ wt. \%) mostly plot at the end of the evolution trends.

\subsection{Trace elements}

In Figure 7c, the $\mathrm{Rb}$ contents of the leucogranites poorly correlate with $\mathrm{SiO}_{2}$ and vary from $\sim 100$ to $600 \mathrm{ppm}$ whereas $\mathrm{Sr}(\sim 10-250 \mathrm{ppm}), \mathrm{Ba}(\sim 20-500 \mathrm{ppm}), \mathrm{Zr}(\sim 30-150 \mathrm{ppm})$ and $\mathrm{La}$ $(\sim 5-35 \mathrm{ppm})$ are negatively correlated with $\mathrm{SiO}_{2}$. Among the leucogranites, samples from the late equigranular leucogranite display the lowest contents in $\mathrm{Ba}, \mathrm{Sr}, \mathrm{Zr}$, $\mathrm{La}$ and the highest 
contents in $\mathrm{Rb}$. Regarding the monzogranites, the $\mathrm{Sr}(\sim 150-450$ ppm), Ba ( 300 - 1300 ppm), $\mathrm{Zr}(\sim 150-300 \mathrm{ppm})$ and $\mathrm{La}(\sim 45-75 \mathrm{ppm})$ contents are negatively correlated with $\mathrm{SiO}_{2}$. The monzogranite samples display continuous evolution trends with the leucogranites. In contrast, the $\mathrm{Rb}$ contents $(\sim 150-200 \mathrm{ppm})$ are low and comparable. The quartz monzodiorite samples display variable $\mathrm{Sr}(\sim 300-650 \mathrm{ppm}), \mathrm{Ba}(\sim 250-1600 \mathrm{ppm})$ and $\mathrm{La}(\sim 20-70 \mathrm{ppm})$ contents which are not correlated with $\mathrm{SiO}_{2}$. The $\mathrm{Zr}$ contents increase with $\mathrm{SiO}_{2}$ from $\sim 175$ to $250 \mathrm{ppm}$. The $\mathrm{Rb}$ contents are comparable to those of the monzogranites and vary slightly between $\sim 100$ and $200 \mathrm{ppm}$. No well-defined correlation exists in the different granitic samples between $\mathrm{SiO}_{2}$ and incompatible elements such as $\mathrm{U}, \mathrm{Cs}, \mathrm{Li}, \mathrm{Ta}, \mathrm{W}$ or $\mathrm{Sn}$.

The chondrite-normalized REE patterns of the different leucogranites are comparable (Fig. 8a). They generally show high fractionation $\left(\mathrm{La}_{N} / \mathrm{Lu}_{N}=5.8-49.2\right)$ and are marked by a negative Eu anomaly $\left(\mathrm{Eu} / \mathrm{Eu}^{*}=0.08-0.90\right)$; sample PONT-21 (late equigranular leucogranite) displays the most pronounced negative anomaly. In the monzogranite (Fig. 8a), the REE patterns also show high fractionation $\left(\mathrm{La}_{N} / \mathrm{Lu}_{N}=25.4-47.1\right)$ but with small negative Eu anomalies $\left(\mathrm{Eu} / \mathrm{Eu}^{*}\right.$ $=0.61-0.88$ ). The REE patterns of the quartz monzodiorite (Fig. 8a) reveal an enrichment in LREE compared to HREE but with less fractionation $\left(\mathrm{LaN}_{N} / \mathrm{Lu}_{\mathrm{N}}=9.1-18.7\right)$ and without a significant Eu anomaly $\left(\mathrm{Eu} / \mathrm{Eu}^{*}=0.87-0.89\right)$. In the multi-element diagram normalized to the primitive mantle (Fig. 8b), leucogranites display patterns characteristic of evolved crustalderived magmatic rocks with marked positive anomalies in incompatible elements such as $\mathrm{Cs}$, $\mathrm{Rb}$ and $\mathrm{U}$ and slight positive anomalies in $\mathrm{Pb}$ and $\mathrm{Cr}$. In contrast, they show negative anomalies in $\mathrm{Sr}, \mathrm{Nb}, \mathrm{Ba}$, Ti and $\mathrm{Co}$. The monzogranites and quartz monzodiorites are characterized by crust-like patterns with negative anomalies in $\mathrm{Nb}-\mathrm{Ta}$, $\mathrm{Ti}$ and $\mathrm{Co}$ as well as positive anomalies in $\mathrm{Pb}$ and $\mathrm{Cr}$. In contrast to the leucogranites and monzogranites, the quartz-monzodiorites are not depleted in compatible elements such as $\mathrm{Ti}, \mathrm{Cr}$ and $\mathrm{Co}$ when compared to the average continental crust. 


\section{Whole-rock Sr-Nd isotopic compositions}

Whole-rock Sr and Sm-Nd analyses from the Pontivy-Rostrenen magmatic complex are reported in Figure 9 and Table 3. For all of the facies, the initial epsilon Nd values calculated at $315 \mathrm{Ma}(\varepsilon \mathrm{Nd}(315))$ are comparable and mostly range from -4.8 to -2.5 with $\mathrm{Nd}$ model ages ( T $_{\text {DM.Nd }}$ ) ranging between $1.49 \mathrm{Ga}$ and $1.23 \mathrm{Ga}$. Two equigranular leucogranites (data from Euzen, 1993) have positive $\varepsilon \mathrm{Nd}(315)$ values of 1.1 and 2.1 ( $\mathrm{T}_{\mathrm{DM} . \mathrm{Nd}}=0.85$ and $\left.0.9 \mathrm{Ga}\right)$. The initial Sr isotope compositions calculated at $315 \mathrm{Ma}\left(\mathrm{I}_{\mathrm{Sr}}(315)\right)$ range from 0.7056 to 0.7068 in the quartz monzodiorites and from 0.7064 to 0.7071 in the monzogranites. These two facies display a well-defined evolution trend in the $\mathrm{I}_{\mathrm{Sr}}(315)$ versus $\mathrm{SiO}_{2}$ diagram (Fig. 9b). For the equigranular and porphyritic leucogranites, most of the $\mathrm{I}_{\mathrm{Sr}}(315)$ values range from 0.7041 to 0.7122. For the late equigranular leucogranite and one equigranular leucogranite (PONT-14), the $\mathrm{I}_{\mathrm{Sr}}(315)$ values are anomalously low and range from 0.6114 to 0.7012 . No correlation exists between the $\mathrm{I}_{\mathrm{Sr}}(315)$ values for the leucogranites and their $\mathrm{SiO}_{2}$ content (Fig. 9b).

In Table 3, we provide five $\mathrm{Sm}-\mathrm{Nd}$ whole-rock sample analyses on Early Paleozoic peraluminous metagranitoids from the Central Armorican domain (Plouguenast) and South Armorican domain (Moelan) (Fig. 1, Table 1). The $\varepsilon \mathrm{Nd}(\mathrm{t})$ values of these samples, recalculated at $315 \mathrm{Ma}$, range from -2.83 to 0.54 with $\mathrm{T}_{\text {DM.Nd }}$ values between 0.99 and $1.25 \mathrm{Ga}$.

\section{Geochronology}

Zircon grains of five samples representing the different magmatic facies were dated by LAICP-MS. In the leucogranites, the zircon population is characterized by generally euhedral translucent grains which can be colorless, grayish or creamy in color. Cathodoluminescence imaging (CL) reveals the presence of numerous grains with growth zoning and/or inherited cores (Fig. 10a-c). 
For the porphyritic leucogranite sample PONT-1, fifty-three analyses were performed on fourty-five zircon grains out of which twenty-seven have a degree of concordance between 90 and $110 \%$ (Fig. 11a). The ${ }^{207} \mathrm{~Pb} /{ }^{206} \mathrm{~Pb}$ dates range from $1750.6 \pm 19.3 \mathrm{Ma}$ down to $304.1 \pm 27.8$ Ma. Eight concordant to sub-concordant analyses obtained on eight different grains (one rim, seven homogeneous grains), allow to calculate a concordia date of $316.7 \pm 2.5 \mathrm{Ma}(\mathrm{MSWD}=$ 1.2) interpreted as the crystallization age. Four analyses display younger apparent ${ }^{206} \mathrm{~Pb} /{ }^{238} \mathrm{U}$ and ${ }^{207} \mathrm{~Pb} /{ }^{235} \mathrm{U}$ dates (dashed ellipses in Fig. 11a). They plot in a sub-concordant to discordant position and probably reflect slight $\mathrm{Pb}$ loss combined with initial common $\mathrm{Pb}$ contamination.

Seventy-four analyses on forty-five different grains were carried out for the equigranular leucogranite sample PONT-26. Forty-eight of these analyses have a degree of concordance between 90 and $110 \%$ (Fig. 11 b). The ${ }^{207} \mathrm{~Pb} /{ }^{206} \mathrm{~Pb}$ dates range from $1982.5 \pm 21.6 \mathrm{Ma}$ down to $289.2 \pm 26.0$ Ma. One group of six analyses obtained on five grains (two rims, three homogenous grains), allows to calculate a poorly constrained concordia date of $310.3 \pm 4.7 \mathrm{Ma}$ $(\mathrm{MSWD}=2.5)$ which is comparable within error to the age obtained for the porphyritic sample. In Figure 11b, the dashed ellipses are explained by the presence of common $\mathrm{Pb}$ and a complex $\mathrm{Pb}$ loss.

Fifty-nine analyses obtained on forty-two grains were performed for the late equigranular leucogranite sample PONT-20. Forty-three analyses have a degree of concordance between 90 and $110 \%$ and present ${ }^{207} \mathrm{~Pb} /{ }^{206} \mathrm{~Pb}$ dates ranging from $2637.9 \pm 17.6 \mathrm{Ma}$ to $287.2 \pm 31.9 \mathrm{Ma}$ (Fig. 11c). Six concordant analyses obtained on four grains (one rim, three homogenous grains), yield a concordia date of $304.7 \pm 2.7 \mathrm{Ma}(\mathrm{MSWD}=0.57)$ that we interpret as the best estimate for the crystallization age. Three analyses, represented by dashed ellipses in Figure 11c, plot in a discordant position and probably reflect a complex $\mathrm{Pb}$ loss and the presence of initial common $\mathrm{Pb}$. In Figure 11d, we have reported all of the U-Pb dates $(90 \%<$ degree of concordance < $110 \%)$ obtained on inherited zircon grains/cores from the leucogranites $(n=70)$. Four main 
populations can be distinguished. The older population $(n=7)$ is Archean to Paleoproterozoic in age (between ca. $2650 \mathrm{Ma}$ and $1750 \mathrm{Ma}$ ). The dates for the other zircon cores/grains define a more or less continuous population from ca. 900 Ma to ca. 330 Ma with a Neoproterozoic population $(\mathrm{n}=28)$ marked by a Cadomian peak at ca. $570 \mathrm{Ma}$, an Ordovician-Cambrian population $(\mathrm{n}=18)$ characterized by a peak at ca. $450 \mathrm{Ma}$ and a Devonian-Carboniferous population $(\mathrm{n}=17)$ with a peak at ca. 380 Ma.

The monzogranite sample PONT-22 provided a large number of generally euhedral translucent zircon grains characterized by a euhedral shape with a colorless, milky, grayish or yellowish color. On the CL images, most of the zircon grains display growing zonation (Fig. 10d). Twenty-nine analyses were performed on twenty-two different grains out of which twenty-five have a degree of concordance between 90 and $110 \%$ (Fig. 11e. The ${ }^{207} \mathrm{~Pb} /{ }^{206} \mathrm{~Pb}$ dates range from $487.5 \pm 30.4$ Ma down to $299.1 \pm 30.5 \mathrm{Ma}$. A group of eighteen concordant to sub-concordant analyses obtained on sixteen grains (three rims, thirteen homogenous grains), allow to calculate a concordia date of $315.5 \pm 2.0 \mathrm{Ma}(\mathrm{MSWD}=1.5)$, which is comparable within error to the ages obtained for the porphyritic and equigranular leucogranites. As a consequence, we suggest that this sample crystallized $315.5 \pm 2.0$ Ma ago. The analyses represented by dashed ellipses in Figure 11e are explained by a complex $\mathrm{Pb}$ loss and the presence of common $\mathrm{Pb}$ whereas the three oldest dates $\left(330.6 \pm 3.6 \mathrm{Ma}<{ }^{206} \mathrm{~Pb} /{ }^{238} \mathrm{U}\right.$ date $<$ $357.9 \pm 3.9 \mathrm{Ma}$ ), represented by grey ellipses and obtained on one grain core and two homogenous grains, are interpreted as inherited (Fig. 11d).

In the quartz monzodiorite sample PONT-7, zircon grains are abundant, generally subeuhedral and characterized by a brownish-honey color. The grains are poorly luminescent on the CL images but they reveal discreet zoning on the BSE images (Fig. 10e). Twenty-four analyses were carried out on twenty-four grains and nineteen analyses have a degree of concordance between 90 and 110\% (Fig. 11f). Among them, a group of seven analyses, 
performed on seven homogenous grains, plot in concordant positions and yield a concordia date of $315.2 \pm 2.9 \mathrm{Ma}(\mathrm{MSWD}=0.94)$ which is comparable to the ages obtained for the porphyritic and equigranular leucogranite as well as the monzogranite. We suggest that this sample crystallized 315.2 \pm 2.9 Ma ago. Dashed ellipses in Figure 11f are interpreted to result from complex $\mathrm{Pb}$ loss and common $\mathrm{Pb}$ contamination.

\section{Zircon Lu-Hf isotope determination}

The Hf isotope compositions are reported in Figure 12 and in Supplementary file 3. For the leucogranite samples (PONT-1, 20 and 26), both magmatic (fifteen analyses) and inherited (fourty-six analyses) zircon grains/domains (Fig. 10a-c) were analyzed, and for the monzogranite (sample PONT-22) and quartz-monzogranite (sample PONT-7) only magmatic grains. For the late equigranular leucogranite (PONT-20), only one analysis could be performed on a magmatic zircon due to the small size of the grains. Magmatic zircon grains/domains in all samples reveal mostly sub-chondritic to chondritic $\varepsilon H f(t)$ values ranging from -2.9 to +2.4 , and corresponding to two-stage hafnium model ages ( $\left.\mathrm{T}_{\mathrm{DM} 2 . \mathrm{Hf}}\right)$ between 1.40 and $1.11 \mathrm{Ga}$, respectively (leucogranites: PONT $-1=-0.6$ to $-2.7, \mathrm{n}=6$; PONT-20 $=+0.9, \mathrm{n}=1$; PONT-26 $=$ -2.9 to $+2.4, \mathrm{n}=5$; monzogranite: PONT-22 $=-2.3$ to $-0.4, \mathrm{n}=14$; quartz monzodiorite: PONT$7=-1.3$ to $+2.1, \mathrm{n}=7$ ). Only three grains/domains in sample PONT-1 show significantly higher $\varepsilon H f(t)$ values of +3.9 to +5.2 (corresponding to lower $\left.\mathrm{T}_{\mathrm{DM} 2 . \mathrm{Hf}}=1.03-0.96\right)$, pointing to a bimodal Hf isotope distribution. The inherited zircon grains/domains show a much wider scatter in $\varepsilon H f(t)$ than the magmatic grains, ranging from -22.8 to +8.4 (Fig. 12b). Most of the initial ${ }^{176} \mathrm{Hf} /{ }^{177} \mathrm{Hf}$ ratios measured on the inherited grains $(\sim 75 \%)$ overlap those obtained on the magmatic grains and show comparable $\mathrm{T}_{\mathrm{DM} 2 . \mathrm{Hf}}$ between 0.95 and $1.4 \mathrm{Ga}$ (see trend in Figure 12b). The remaining $25 \%$ display much older hafnium model ages ranging between ca. 2.0 and $3.0 \mathrm{Ga}$. 


\section{Discussion}

\subsection{Petrogenesis}

\subsubsection{Source characterization}

The highly peraluminous character of the leucogranites from the Pontivy-Rostrenen complex (A/CNK > 1.1; Figs. 5b and 6a), together with their major element compositions (Fig. 6b-c) and trace element patterns (Fig. 8), point to a crustal origin. This interpretation is also consistent with the elevated $\delta^{18} \mathrm{O}$ whole-rock values of $12.5 \%$ and $12.8 \%$ obtained on porphyritic and equigranular leucogranites by Bernard-Griffiths et al. (1985). In Figure 9a, the $\varepsilon \mathrm{Nd}(315)$ values of the leucogranites overlap those from the Brioverian (Late Proterozoic) sediments and the Paleozoic peraluminous orthogneisses (metavolcanics and metagranitoids). U-Pb analyses (Fig. 11a-c) and CL images (Fig. 10a-c) of zircon reveal the presence of inherited grains/cores with four main age populations between $\sim 700$ and $340 \mathrm{Ma}$ (Fig. 11d). The presence of Paleozoic inherited zircon grains (340 - 540 Ma) indicates that the leucogranites were not only formed by partial melting of Brioverian (> $\sim 540 \mathrm{Ma})$ sediments and that Paleozoic peraluminous orthogneisses were additionally involved.

This interpretation is supported by $\varepsilon \mathrm{Nd}$ values and the fact that approximately $75 \%$ of the inherited zircon grains (340-700 Ma) in the leucogranite samples show the same range of initial ${ }^{176} \mathrm{Hf} /{ }^{177} \mathrm{Hf}$ values (and Hf model ages) than the ca. 315 Ma old magmatic grains (Fig. 12b). This feature is similar to that of zircon grains in the S-type Cape granite suite (South Africa), where the Hf isotopic variability in the magmatic zircon grains is nearly identical to that of the inherited zircon population, suggesting that the heterogeneity of the Hf signatures is directly inherited from the source (Villaros et al., 2012; Farina et al., 2014). Thus, we propose that the Hf isotope heterogeneity of the magmatic zircon grains in our samples (comprising the bimodality in sample PONT-1) is a result of an incomplete homogenization of the (inherited) 
Hf isotope system (on the sample scale) during the formation of the leucogranitic magmas. The modeling of the zircon dissolution by Farina et al. (2014) suggests that sub-mm domains with variable Hf isotope compositions can be created in a granitic melt, whereby the composition of such domains is controlled by the size and isotopic signature of the nearest dissolving zircon crystal as well as the cooling rate of the magma.

The whole-rock $\mathrm{I}_{\mathrm{Sr}}(315)$ values for the leucogranites vary from $\sim 0.7040$ to 0.7125 with three samples displaying abnormally low $\mathrm{I}_{\mathrm{Sr}}(315)$ values $<0.7015$ (Fig. 9a). This spread of the ISr values may reflect heterogeneities in the source of the leucogranites or may result from mineral-scale isotopic disequilibrium during partial melting reactions (Farina and Stevens, 2011). Hydrothermal alteration processes may also have played a role as $\mathrm{Rb}$ has a strong affinity for orthomagmatic fluids (e.g. Shaw, 1968). The two samples with $\mathrm{I}_{\mathrm{Sr}}(315)$ values $<0.7015$ represent highly evolved Ms leucogranites (PONT-14 and 21) which likely experienced significant hydrothermal interactions, suggesting that magmatic-hydrothermal alteration processes are involved in the decrease of the $\mathrm{I}_{\mathrm{Sr}}$ values.

The monzogranites are characterized by high $\mathrm{I}_{\mathrm{Sr}}(315)$ and negative $\varepsilon \mathrm{Nd}(315)$ values (Fig. 9a) and sub-chondritic zircon $\varepsilon \mathrm{Hf}(\mathrm{t})$ values (Fig. 12a). These results, together with the moderately peraluminous signature of the samples $(\sim 1<\mathrm{A} / \mathrm{CNK}<1.3$; Figs. $5 \mathrm{~b}$ and $6 \mathrm{a})$, their major element compositions (Fig. 6b-c), their crustal-like trace element patterns (Fig. 8) and the scarce Paleozoic inherited zircon grains (Figs. 10d and 11d-e), suggest that the monzogranites were mostly formed by partial melting of a metaluminous igneous source.

The quartz monzodiorite samples display crustal-like trace element patterns (Fig. 8) and provide high $\operatorname{ISr}_{\mathrm{Sr}}(315)$, sub-chondritic $\varepsilon \mathrm{Nd}(315)$ and chondritic zircon $\varepsilon \mathrm{Hf}(\mathrm{t})$ values (Figs. 9a and 12a) that are, usually, characteristic of a crustal source. However, their metaluminous signature (Fig. 6a), their major element compositions (Fig. 6b-c), their elevated $\mathrm{Cr}$ and $\mathrm{Co}$ 
contents (Fig. 8) suggest a mantle-derived origin. Indeed, the quartz monzodiorite samples display whole-rock major element (Fig. 6d) and radiogenic isotopic compositions (Fig. 9a) that are similar to those obtained for the magneso-potassic $(\mathrm{Mg}-\mathrm{K})$ calc-alkaline post-collisional mafic magmatic rocks from the Variscan belt, locally called appinites in Iberia (e.g. Scarrow et al., 2009; Molina at al., 2012) and kersantites or vaugnerites in France (e.g. Turpin et al., 1988; Couzinié et al., 2014, 2016; Moyen et al., 2016; Laurent et al., 2017). Mg-K mafic magmatic rocks are commonly found associated with post-collisional granites and are interpreted as resulting from the partial melting of a metasomatized lithospheric mantle mostly made of phlogopite- \pm amphibole-bearing peridotites (e.g. Bonin, 2004; Condamine and Médard, 2014; Couzinié et al., 2016; Moyen et al., 2016). The enrichment in LILE, $\mathrm{K}_{2} \mathrm{O}$ and $\mathrm{H}_{2} \mathrm{O}$ of the subcontinental lithospheric mantle by fluids and/or melt interactions during Variscan subduction events can explain the apparent crustal signatures of these igneous rocks (e.g. Yoshikawa et al., 2010; Gordon Medaris Jr. et al., 2015; Laurent and Zeh, 2015; Couzinié et al., 2016; Moyen et al., 2016). An origin predominantly from an enriched mantle source for the quartz monzodiorites is consistent with the lack of inherited zircon grains.

\subsubsection{Timing and duration of emplacement}

The ages (Fig. 11) obtained for the porphyritic (316.7 $\pm 2.5 \mathrm{Ma})$ and equigranular $(310.3 \pm$ 4.7 Ma) leucogranites, for a monzogranite $(315.5 \pm 2.0 \mathrm{Ma})$ and a quartz monzodiorite $(315.2$ $\pm 2.9 \mathrm{Ma}$ ) are comparable within error. We suggest that the majority of the Pontivy-Rostrenen magmatic complex was emplaced ca. $315 \mathrm{Ma}$ ago. The fact that the emplacement ages obtained for the different magmatic units are contemporaneous is consistent with field observations which revealed mingling features at the contact between the monzogranite and the quartz monzodiorite (Fig. 3d). The slightly younger and poorly constrained concordia date of $310.3 \pm$ 4.7 $\mathrm{Ma}(\mathrm{MSWD}=2.5$ ) obtained on the equigranular leucogranite is likely due to a complex combination of $\mathrm{Pb}$ loss and common $\mathrm{Pb}$ contamination (Fig. 11b). The zircon $\mathrm{U}-\mathrm{Pb}$ age of ca. 
$315 \mathrm{Ma}$ obtained on our samples is younger than the $\mathrm{Rb}-\mathrm{Sr}$ isochron date of $344 \pm 8 \mathrm{Ma}$ previously obtained by Peucat et al. (1979) for the Pontivy leucogranite but is in good agreement with the muscovite ${ }^{40} \mathrm{Ar}^{39} \mathrm{Ar}$ date of ca. $311 \mathrm{Ma}$ (Cosca et al., 2011) which can be interpreted as a cooling age. As previously observed for the neighboring Lizio (Tartèse et al., 2011a) and Questembert (Tartèse et al., 2011b) leucogranites (Fig. 1), the Rb-Sr isochron method yields an older date confirming that this system is not suitable to accurately date the emplacement and/or to trace the sources of peraluminous leucogranite intrusions. In agreement with cartographic criteria which suggest late emplacement of the late equigranular leucogranite (Fig. 2), zircon $\mathrm{U}-\mathrm{Pb}$ dating of this facies yields a concordia age of $304.7 \pm 2.7 \mathrm{Ma}$ (Fig. 11c). At a regional scale, the crystallization age of ca. 315 Ma obtained on the Pontivy-Rostrenen granitoids is consistent with the ages found for other granites emplaced either along the SASZ such as the Lizio (316.4 \pm 5.6 Ma; U-Pb Zrn; Tartèse et al., 2011a) and Questembert (316.1 \pm 2.9 Ma; U-Pb Zrn; Tartèse et al., 2011b) leucogranites or along the NASZ such as the Saint Renan granite (316.0 \pm 2.0 Ma; U-Pb Zrn; Le Gall et al., 2014) (Fig. 1). The emplacement of the late equigranular leucogranite at $304.7 \pm 2.7 \mathrm{Ma}$ is synchronous with the late magmatic pulse recorded in the Guérande leucogranite ca. 303 Ma ago (Ballouard et al., 2015a) and with hydrothermal circulations dated in the Questembert leucogranite (Tartèse et al., 2011b).

\subsubsection{Magmatic history}

Granitoids commonly display geochemical heterogeneities both at the sample and intrusion scales, which can be linked to petrogenetic processes such as (i) fractional crystallization (e.g. Tartèse and Boulvais, 2010; Morfin et al., 2014; Ballouard et al., 2015a; Simons et al., 2016), (ii) magma hybridization (e.g. Castro et al., 1999; Patiño-Douce, 1999; Healy et al., 2004), (iii) country rock assimilation (e.g. DÍaz-Alvarado et al., 2011), (iv) restite unmixing (Chappell et al., 1987) and (v) peritectic phase entrainment (e.g. Stevens et al., 2007; Villaros et al., 2009a, 2009b; Clemens and Stevens, 2012). 
The peraluminous leucogranites from the Pontivy-Rostrenen complex have major element compositions similar to the products of partial melting experiments on sedimentary and igneous rocks (Fig. $6 \mathrm{~b}$ and c), suggesting that they are crustal melts and that the degree of mixing with mantle-derived magmas, assimilation of country rocks or entrainment of peritetic and restite minerals from the source are negligible. In bivariate diagrams (Fig. 7b and c), the leucogranite samples delineate trends which likely reflect the fractional crystallization of biotite, K-feldspar and plagioclase ( \pm apatite). Modeling using major elements (Fig. 7b) suggests that the evolution from low- to high- $\mathrm{SiO}_{2}$ samples is best explained by the segregation of $\sim 20 \mathrm{wt} . \%$ of a cumulate composed of these minerals (modeling details are provided in Fig. 7 and Supplementary file 5). The scattering of the analyses may reflect source heterogeneities. In Figure 13, the $\mathrm{K}_{2} \mathrm{O}, \mathrm{CaO}$ and $\mathrm{Na}_{2} \mathrm{O}$ compositions for the more primitive leucogranite samples, with $\mathrm{SiO}_{2}$ contents between 70.8 and 72.3 wt.\% (Fig. 7b), are reported cartographically. On this map, one can observe a zonation of the $\mathrm{K}_{2} \mathrm{O}$ and $\mathrm{CaO}-\mathrm{Na}_{2} \mathrm{O}$ contents independently from the petrographic facies: the southwestern part of the massif is mostly characterized by a $\mathrm{K}_{2} \mathrm{O}$ content $>5.0 \mathrm{wt} . \%$ and a $\mathrm{CaO}$ content $<0.7$ wt. $\%$, whereas the eastern and northern parts are mostly characterized by a $\mathrm{K}_{2} \mathrm{O}$ content $<5.0$ wt. $\%$ and $\mathrm{CaO}$ and $\mathrm{Na}_{2} \mathrm{O}$ contents $>0.7$ and 3.0 wt. $\%$, respectively. This zonation suggests partial melting of a K-rich source to the southwest whereas a Ca-Narich source was involved to the north and east. This spatial variation in the source correlates with the regional metamorphism which increases from NE to SW (Fig. 2a) and suggests a difference in the depth of partial melting. Both $\mathrm{Ba}$ and $\mathrm{Sr}$ are negatively correlated with $\mathrm{SiO}_{2}$ (Fig. 7c) which is consistent with the fractional crystallization of feldspar and biotite ( \pm apatite) (e.g. Hanson, 1978). The roughly defined correlation between $\mathrm{Rb}$ and $\mathrm{SiO}_{2}$ for the leucogranite samples reflects the incompatible behavior of $\mathrm{Rb}$ in peraluminous melts and likely fluid-melt or fluid-rock interactions processes (e.g. Shaw, 1968). For the leucogranites, $\mathrm{Zr}$ and La negatively correlate with $\mathrm{SiO}_{2}$ (Fig. 7c), which is consistent with the fractionation of zircon and 
monazite commonly hosted in biotite. Among the leucogranites, the $\mathrm{SiO}_{2}$-rich late equigranular leucogranite samples fall at the end of the evolution trends as they experienced a higher degree of differentiation (Fig. 7).

The composition and isotopic signatures of the quartz monzodiorite samples suggest that they mostly formed by partial melting of a metasomatized mantle source. Subsequent assimilation of crustal-derived melts is reflected by mingling features, occurring at the contact between monzogranites and quartz monzodiorites (Fig. 3d), as well as by ocellar quartz in the quartz monzodiorite samples (Fig. 4d) (e.g. Baxter and Feely, 2002). Modeling based on the $\mathrm{SiO}_{2}$ contents and $\mathrm{I}_{\mathrm{Sr}}$ compositions (Fig. 9b) also points to a hybrid origin with the assimilation of $40 \%$ of a high- $\mathrm{SiO}_{2}\left(>70\right.$ wt. $\%$ ) monzogranitic magma by a low- $\mathrm{SiO}_{2}(\leq 55$ wt.\%) quartz monzodioritic magma to explain the compositional variation observed in the Harker diagrams (Fig. 7a). This amount of mixing is likely unrealistic due to the viscosity differences between felsic and mafic magmas and to the fact that it would imply an enormous amount of mafic melts (e.g. Laumonier et al., 2014; 2015 and reference therein). Moreover, the scattering of the analyses in the bivariate diagrams (Fig. 7a and c) suggests that high-SiO ${ }_{2}$ samples also experienced fractional crystallization of biotite, plagioclase and clinopyroxene. The AFC (assimilation-fractional crystallization) modeling is consistent with this hypothesis and shows that the chemical variations in the samples can be explained by a $\sim 25 \mathrm{wt} . \%$ segregation of a cumulate composed of An70 + Cpx + Bt and a $20 \mathrm{wt} . \%$ assimilation of an acid magma with the average composition of the high-SiO $\mathrm{Si}_{2}(>70 \mathrm{wt} . \%$ ) monzogranite samples (details of the modeling are provided in Fig. 7 and Supplementary file 5). The large variability in the $\mathrm{Ba}, \mathrm{Sr}$ and La contents for the quartz monzodiorite samples is likely due to the combination of both processes, whereas $\mathrm{Zr}$ behaves as an incompatible element with a content that increases during differentiation (Fig. 7c). In contrast to magma mixing and fractional crystallization, the 
sedimentary country rock assimilation by itself cannot explain the chemical variations displayed by the samples (Fig. 7a).

In contrast with the leucogranites, several monzogranite samples have whole-rock compositions that differ from the composition of a melt produced during the experimental partial melting of crustal rocks. Therefore, the well-defined evolution trends displayed by the monzogranites in the bivariate diagrams (Fig. 7a and 7c) cannot be explained by fractional crystallization. In the Harker diagrams (Fig. 7a), the assimilation of country rocks cannot reproduce the trends followed by the monzogranites. In addition, these samples do not contain a significant amount of restitic materials (i.e. unmolten source rocks). Therefore, none of these two processes can account for the evolution of the monzogranites. Conversely, the model that involves a mixing between the high- $\mathrm{SiO}_{2}$ monzogranite and quartz monzodiorite samples reproduces the trends displayed by the monzogranite samples rather well (Figs. 7a-c and 9b), with the monzogranite magma assimilating up to $30 \%$ of a quartz monzodiorite magma. As specified above, this amount of mixing seems unrealistic and mineralogical textures like Rapakivi feldspar that are generally observed in hybrid granitoids are absent in the monzogranites (e.g. Baxter and Feely, 2002). On the other hand, we previously showed that the quartz monzodiorites represent hybrid magmas so we do not have access to the initial mantle melt composition, meaning that the amount of mixing might be much lower than $30 \%$. This hypothesis would account for the elevated Ba content in the monzogranites as it cannot be solely explained by a simple mixing with the quartz monzodiorites. Alternatively, metaluminous igneous rocks, proposed as the main source for the monzogranites, typically melt via the reaction: $\mathrm{Bt}+\mathrm{Hbl}+\mathrm{Qtz}+\mathrm{Pl}^{1}=$ melt $+\mathrm{Pl}^{2}+\mathrm{Cpx}+\mathrm{Opx}+\mathrm{Ilm} \pm$ Grt (Clemens et al., 2011). The entrainment of peritectic minerals formed during this partial melting reaction could account for the trend displayed by the monzogranites (Fig. 7a). Peritectic mineral entrainment modeling shows that the evolution from a high $\mathrm{SiO}_{2}(>70$ wt.\%) to the low-SiO 2 sample PONT-22 can 
be explained by the addition of $\sim 15 \mathrm{wt} . \%$ of an assemblage composed of Grt $+\mathrm{Cpx}+\mathrm{Pl} \pm \mathrm{Ilm}$ (modeling details are provided in Fig. 7 and Supplementary file 5). Peritectic minerals are not expected to be identified in granitic rocks as the small grain size of these crystals facilitates the reequilibration with the magma during the ascent and emplacement. Ferromagnesian minerals such as clinopyroxene can react with a melt to form biotite, and garnet can break down into cordierite or biotite at low pressure (Stevens et al., 2007; Clemens and Stevens, 2012). The negative correlation between $\mathrm{SiO}_{2}$ and trace elements such as $\mathrm{Zr}$ and $\mathrm{La}$ should reflect variable degrees of entrainment of zircon and monazite from the source, respectively (Villaros et al., 2009) (Fig. 7c). However, these accessory minerals likely reequilibrated with the melt, as evidenced by the scarcity of inherited zircon grains in the monzogranite. In contrast to the less viscous $\mathrm{H}_{2} \mathrm{O}$-rich leucogranites which experienced significant fractional crystallization, we suggest that the monzogranites were more affected by a peritectic and accessory phase entrainment due to their higher viscosity and because they likely resulted from a higher degree of partial melting. Finally, we suggest that the monzogranites could have evolved via the combination of peritectic phase entrainment and hybridization with a mantle-derived melt.

\subsection{Magma generation model and implication for the tectono-magmatic evolution of the Variscan Armorican belt}

This section aims to present an interpretation of the tectono-magmatic history of the Armorican Massif at the end of the Variscan orogeny.

In the previous section, we conclude that the leucogranites from the Pontivy-Rostrenen complex result from the partial melting of Neoproterozoic metasediments and Paleozoic peraluminous plutonic rocks. The partial melting zone from which the leucogranite melts migrated could be a northern equivalent of the migmatites found in the southern part of the Armorican Massif (Fig. 1). These migmatites, which are mostly composed of Pre- 
Carboniferous metasediments and Paleozoic orthogneisses (e.g. Augier et al., 2011), reached a peak P-T conditions of $\sim 0.8 \mathrm{GPa}-\sim 800^{\circ} \mathrm{C}$ and melting occurred from water-saturated solidus to biotite breakdown conditions (Jones and Brown, 1990). Considering a Barrovian geothermal gradient of $30^{\circ} \mathrm{C} / \mathrm{km}$, the partial melting along the SASZ, triggered by either shear heating or hydrous fluxing, could have occurred at a depth of 20 km (Strong and Hanmer, 1981). In contrast, quartz monzodiorite produced by partial melting of a lithospheric mantle, probably metasomatized during the oceanic then continental subductions below the Armorica microplate until the Late Devonian - Early Carboniferous times (e.g. Faure et al., 1997; 2005; Bosse et al., 2005; Ballèvre et al., 2009, 2013, 2014). Metasomatized lithospheric mantle domains composed of phlogopite- \pm amphibole-bearing lherzolites are particularly prone to melting at solidus temperatures as low as $1050^{\circ} \mathrm{C}$ at $1 \mathrm{GPa}(\sim 30 \mathrm{~km}$; Conceição and Green, 2004; Condamine and Médard, 2014). With regards to the monzogranites, they are likely derived from the melting of a metaluminous metaigneous source. Partial melting of metaluminous igneous rocks reflects elevated melting temperatures which can result from the underplating of mafic magma melts (e.g. Huppert and Sparks, 1988; Petford and Gallagher, 2001 and Annen and Sparks, 2002). The higher temperatures of the monzogranitic magma compared to the leucogranitic magma are confirmed by the presence of a contact metamorphism aureole surrounding the monzogranites (Fig. 2). The rising of the different magmas into the upper crust to a depth of 26-8 km (Vigneresse, 1999) was likely promoted by the shearing along the SASZ and the second order strike-slip faults (Hutton, 1988; D’Lemos et al., 1992) (Figs. 1 and 14).

At the scale of both the Pontivy-Rostrenen complex and Armorican Massif, the influence of mantle-derived melts increases from south to north (Capdevila, 2010; Fig. 1b). A first explanation could be that mantle melting occurred independently from the latitude below the Armorican Massif but that the thickness of the crust to the south of the SASZ prevented the ascent of mantle-derived magma into the upper crustal levels. However, it seems very unlikely 
that no mantle-derived magma reached the upper crust considering their low viscosity when compared to crustal melts (e.g. Scaillet et al., 1998). Moreover, both the $\varepsilon \mathrm{Nd}(315)$ and $\mathrm{I}_{\mathrm{Sr}}(315)$ values decrease, from northwest to southeast (i.e. from the Pontivy and Lizio leucogranites to the Guérande leucogranite; Figs. 1 and 9a), demonstrating a more pronounced crustal signature for the leucogranites southward (Bernard-Griffiths et al., 1985; Ballouard et al., 2015). Thus, we suggest that mantle melting was restricted to the north of the SASZ. The main geodynamic processes allowing for the concomitant melting of crustal and mantle sources in a late orogenic context are (i) mechanical delamination of a lithospheric mantle root (e.g. Houseman et al., 1981; Molnar and Houseman, 2004), (ii) post-thickening extension (e.g. Malavieille et al., 1990; Gardien et al., 1997; Vanderhaeghe and Teyssier, 2001) including a slab-retreat driven lithospheric thinning (Brun and Faccenna, 2008; Vanderhaeghe and Duchêne, 2010; Moyen et al., 2016; Laurent et al., 2017), (iii) orocline-driven lithospheric thinning (Gutiérrez-Alonso et al., 2011) or (iiii) slab breakoff (e.g. Davies and von Blanckenburg, 1995; Janoušek and Holub, 2007; Duretz et al., 2011; van Hunen and Allen, 2011). The first process is unlikely to have taken place to the north of the SASZ, as it involves a thickened continental crust. There is no evidence for an extensional regime in the Northern and Central domains, precluding the second process. Indeed, sedimentary basins mostly filled with Lower Carboniferous sediments such as the transpressive Chateaulun basin (Fig. 1) formed in response to strike-slip deformation (Gumiaux et al., 2004a). Gutiérrez-Alonso et al. (2011) also proposed that the formation of the Iberian-Armorican Arc during the Late Carboniferous induced the thinning of the subcontinental lithospheric mantle below the outer arc which, in turn, resulted in the production of a bimodal magmatism. However, this model, which involves the bending of an extremely thickened lithosphere in the inner part of the belt, does not explain the crustal extension observed in the South Armorican domain around 310-300 Ma and the absence of a major extensional event in the Central and Northern domains (e.g. Gapais et al., 2015). In contrast, a 
slab breakoff could have induced an asthenosphere upwelling below the Central and Northern domains without causing a crustal extension. The Central and Northern Armorican domains are limited by two major Variscan suture zones (Fig. 15). The first one, to the north, resulted from the collision between Laurussia (Avalonia) and Armorica and is associated with the southward subduction of the Rheic Ocean (e.g. Ballèvre et al., 2009; 2013; Faure et al., 1997, 2005). The second one, to the south, related to the collision between Gondwana and Armorica, is associated with the northward subduction of the Galicia - Massif Central Ocean (GMCO; e.g. Ballèvre et al., 2013; 2014). The tomographic images of the mantle below the Armorican Massif highlight a velocity anomaly interpreted as an oceanic lithosphere remnant, likely corresponding to the GMC oceanic plate, steeply dipping to the NE (Gumiaux et al., 2004b). The fact that this slab remained below the Armorican Massif since the Carboniferous suggests that it is still connected laterally to the South Armorican continental crust and that breakoff was incomplete. In parallel, slab tearing may have been triggerred during the Carboniferous by dextral shearing along the SASZ, this lithospheric-scale wrench fault representing the suture zone between Gondwana and Armorica in this part of the Armorican Massif (Gumiaux et al., 2004b; Ballèvre et al., 2009, 2013) (Figs. 14 and 15). Gumiaux et al. (2004a) showed that a pervasive strike-slip deformation affected the whole Central Armorican Domain during the Carboniferous and Gumiaux et al. (2004b) proposed that this lithospheric-scale wrenching induced a horizontal shearing of the oceanic slab remnant localized below this area at a depth of approximately $130 \mathrm{~km}$ close to the lithosphere-asthenosphere boundary. This event, by creating an asthenospheric window, potentially enhanced the asthenosphere upwelling below the Central and Northern Armorican domains, resulting in a bimodal magmatism (Fig. 14).

The fact that mantle melting only occurred to the north of the SASZ probably results from a specific composition of the corresponding lithospheric mantle. Indeed, mantle-derived igneous rocks from the Pontivy-Rostrenen complex (Fig. 9), but also mafic rocks from the Late 
Carboniferous Ploumanac'h composite intrusion, both located to the north of the SASZ (Fig. 1), show isotopic signatures typical for crustal rocks $\left(-1.65<\varepsilon \mathrm{Nd}(315)<-0.51\right.$ and $\mathrm{ISr}_{\mathrm{Sr}}(315)>$ 0.704 for Ploumanac'h), suggesting that they were formed by partial melting of an enriched lithospheric mantle source. Enrichment of the lithospheric mantle probably occurred between ca. 350 and $320 \mathrm{Ma}$, as suggested by isotopic data on the Saint-Jean-du-Doigt mafic complex (north of the Pontivy-Rostrenen complex, Fig. 1). Indeed, this complex which was emplaced ca. 347 Ma ago (Caroff et al., 2011; Barboni et al., 2011), in potential relation with the Rheic subduction (Faure et al., 1997, 2005), is characterized by superchondritic $\varepsilon N d(347)$ values from 2.4 to 6.9 (Caroff et al., 2011; Barboni et al., 2011). Therefore, we suggest that only the mantle localized below the Central and Northern Armorican domains, representing a hanging plate during the Devonian to Early Carboniferous subduction events, was significantly fertilized.

To summarize, in the internal part of the Armorican Variscan belt, i.e. to the south of the SASZ, crustal magmatism was apparently triggered by lithosphere thinning and adiabatic decompression during extensional tectonics. In the external parts of the belt, i.e. to the north of the SASZ, asthenosphere upwelling controlled by slab tearing during strike-slip deformation induced the concomitant melting of the crust and an enriched mantle fertilized during earlier subductions. A south-north zonation in the Pontivy-Rostrenen magmatic complex, localized at the transition between the internal and external zones, highlights the role of the SASZ in delimiting lithospheric domains with distinct magmatic systems.

This process is likely not restricted to the Armorican Massif and also affected other regions in the Variscan belt. The Central Iberian (CIZ) and the Ossa-Morena zones (OMZ), in the Iberian Massif, underwent a tectono-magmatic evolution comparable to that of the Central and Northern Armorican domains (Fig. 15). Firstly, the CIZ and OMZ are boarded by two strikeslip faults interpreted as the GMC and Rheic suture zones, respectively (Ballèvre et al., 2009; 2013). Then, the CIZ and OMZ were poorly deformed during the Variscan orogeny, as crustal 
extension was only localized in the internal part of the belt (i.e. the Galicia-Trás-os-Montes [GTMZ] and West Asturian-Leonese [WALZ] zones) and the eastern part of the CIZ (HT metamorphism in Fig. 15) (e.g. Martínez Catalán et al., 2014). Finally, as for the Armorican Massif, crustal-derived biotite + muscovite leucogranites were mostly emplaced in the internal part of the belt (i.e. GTMZ) between ca. 320 and 305 Ma (e.g. Martínez Catalán et al., 2014 and reference therein), whereas magmatism in the CIZ and OMZ is dominated by biotite $( \pm$ cordierite) or biotite ( \pm hornblende) granitoids, emplaced between ca. 325 and 285 Ma (e.g. Martínez Catalán et al., 2014 and reference therein), interpreted as hybrid in origin (Castro et al., 1999) or resulting from an elevated degree of crustal melting.

\section{Conclusion}

The Pontivy-Rostrenen magmatic complex was emplaced along the SASZ between a thick crustal domain affected by extension to the south and a relatively thin domain subjected to dextral wrenching to the north (e.g. Gapais et al., 2015). The southern part of the intrusion is composed of peraluminous leucogranites whereas moderately peraluminous monzogranites and metaluminous quartz monzodiorites outcrop in the northern part. This magmatic complex displays compositional spatial changes which mimic Late Carboniferous magmatism in the whole Armorican Massif and documents the northward increase of the contribution of mantlederived melts. The petro-geochemical and geochronological study of the Pontivy-Rostrenen complex leads to the following conclusions:

(1) Major element and Sr-Nd isotope compositions of the bulk rocks, combined with zircon $\mathrm{U}-\mathrm{Pb}$ ages and $\mathrm{Hf}$ isotope data, suggest that the leucogranites were predominately formed by the partial melting of Late Proterozoic sediments with a contribution from Early Paleozoic peraluminous plutonic rocks. In contrast, monzogranites resulted from the partial melting of metaluminous igneous rocks in 
the lower crust, and quartz monzodiorites derived from partial melting of a metasomatized lithospheric mantle source.

(2) The magmatic evolution of the leucogranites was controlled by fractional crystallization. In contrast, the compositional trend of the monzogranites is explained either by a mixing between crust- and mantle-derived magmas and/or the selective entrainment of peritectic minerals into the crustal melt. The magmatic history of the quartz monzodiorite samples is mainly controlled by fractional crystallization as well as hybridization with a crustal-derived magma with a probable monzogranitic composition.

(3) U-Pb dating of magmatic zircon grains is in agreement with field observations and demonstrates that leucogranites, monzogranites and quartz monzodiorites were emplaced contemporaneously at ca. $315 \mathrm{Ma}$. A late leucogranitic intrusion (i.e. the late equigranular leucogranite) was emplaced at ca. $305 \mathrm{Ma}$.

Underplating of metasomatized mantle-derived melts beneath the Pontivy-Rostrenen complex enhanced crustal partial melting and hybridization processes between crustal- and mantle-derived melts. At the scale of the Armorican Massif, crustal melting to the south of the SASZ was triggered by crustal extension whereas bimodal magmatism to the north of the SASZ from $\sim 320$ to $300 \mathrm{Ma}$ was likely controlled by oceanic slab tearing and subsequent asthenosphere upwelling during diffuse wrenching of the Central Armorican domain. Due to the injection of crustal materials during earlier subduction events until ca. $350 \mathrm{Ma}$, the mantle below the Central and Northern domains was more prone to partial melting than the mantle to the south of the suture zone (i.e. the SASZ in the western part of the Armorican Massif). At a larger scale, this study highlights the relationship between lithospheric wrenching and bimodal magmatism in a weakly thickened continental domain. The ideas presented here likely apply 
elsewhere in the Variscan belt, for example in the Iberian Massif, where similar tectonomagmatic conditions were encountered during the Variscan orogeny.

\section{Acknowledgment}

This study was supported by 2012-2013 NEEDS-CNRS and 2015-CESSUR-INSU (CNRS) research grants attributed to Marc Poujol. Many thanks to Y. Lepagnot, X. Le Coz and D. Vilbert (Geosciences Rennes) for crushing the samples, realizing the thin-sections and performing radiogenic isotope analyses ( $\mathrm{Sm}-\mathrm{Nd}$ and $\mathrm{Sr}$ ), respectively. We are grateful to $\mathrm{F}$. Gouttefangeas (CMEBA - Université de Rennes 1) and J. Langlade (IFREMER, Brest) for technical support during the SEM and EPMA analyses, respectively. We would like to thank A. Villaros, J.P. Brun, Y. Branquet and E. Hallot for fruitful discussions. This manuscript benefited from the suggestions and comments of two anonymous reviewers. We also acknowledge T. Gerya for his editorial handling. S. Mullin, a professional translator, proofread the manuscript.

\section{References}

Annen, C., Sparks, R.S.J., 2002. Effects of repetitive emplacement of basaltic intrusions on thermal evolution and melt generation in the crust. Earth and Planetary Science Letters 203, 937-955. doi:10.1016/S0012-821X(02)00929-9

Augier, R., Menier, D., Van Vliet-Lanoë, B., Chauris, L., Thinon, I., Mougin, B., Hallegouët, B. Notice explicative, Carte géologique de France (1/50 000), Vannes - Saint-Gildas-de-Rhuys, 417. Bureau de Recherches Géologiques et Minières.

Ballèvre, M., Martínez Catalán, J.R., López-Carmona, A., Pitra, P., Abati, J., Díez Fernández, R., Ducassou, C., Arenas, R., Bosse, V., Castiñeiras, P., Fernández-Suárez, J., Gómez Barreiro, J., Paquette, J.L., Peucat, J.J., Poujol, M., Ruffet, G., Sánchez Martínez, S., 2014. Correlation of 
the nappe stack in the Ibero-Armorican arc across the Bay of Biscay: a joint French-Spanish project. Geological Society, London, Special Publications 405, 77-113. doi:10.1144/SP405.13

Ballèvre, M., Bosse, V., Dabard, M.P., Ducassou, C., Fourcade, S., Paquette, J.-L., Peucat, J.-J., Pitra, P., 2013. Histoire Géologique du massif Armoricain : Actualité de la recherche. Bulletin de la Société Géologique et Minéralogique de Bretagne (D), 10-11, 5-96.

Ballèvre, M., Fourcade, S., Capdevila, R., Peucat, J.J., Cocherie, A., Fanning, C.M., 2012. Geochronology and geochemistry of Ordovician felsic volcanism in the Southern Armorican Massif (Variscan belt, France): Implications for the breakup of Gondwana. Gondwana Research 21, 1019-1036. doi:10.1016/j.gr.2011.07.030

Ballèvre, M., Bosse, V., Ducassou, C., Pitra, P., 2009. Palaeozoic history of the Armorican Massif: Models for the tectonic evolution of the suture zones. Comptes Rendus Geoscience 341, 174 201. doi:10.1016/j.crte.2008.11.009

Ballouard, C., 2016. Origine, évolution et exhumation des leucogranites peralumineux de la chaîne hercynienne armoricaine : implication sur la métallogénie de l'uranium, $\mathrm{PhD}$ thesis, Université de Rennes 1.

Ballouard, C., Poujol, M., Jolivet, M., Boulvais, P., Tartese, R., Dubois, C., Hallot, E., Dabard, M.P., Ruffet, G., 2015b. Geochronological and Thermochronological Constraints on the Carboniferous Magmatism from the Armorican Massif: from the source to the exhumation. The Variscan belt: correlations and plate dynamics, Variscan Conference 2015, Rennes (France), 911 June 2015.

Ballouard, C., Boulvais, P., Poujol, M., Gapais, D., Yamato, P., Tartèse, R., Cuney, M., 2015a. Tectonic record, magmatic history and hydrothermal alteration in the Hercynian Guérande leucogranite, Armorican Massif, France. Lithos 220-223, 1-22. doi:10.1016/j.lithos.2015.01.027

Barak, S., Klemperer, S.L., 2016. Rapid variation in upper-mantle rheology across the San Andreas fault system and Salton Trough, southernmost California, USA. Geology 44, 575-578. doi:10.1130/G37847.1

Barbarin, B., 1999. A review of the relationships between granitoid types, their origins and their geodynamic environments. Lithos 46, 605-626. doi:10.1016/S0024-4937(98)00085-1 
Barboni, M., Bussy, F., Chiaradia, M., 2011. Origin of Early Carboniferous pseudo-adakites in northern Brittany (France) through massive amphibole fractionation from hydrous basalt. Terra Nova 23, 1-10. doi:10.1111/j.1365-3121.2010.00974.x

Barboni, M., Schoene, B., Ovtcharova, M., Bussy, F., Schaltegger, U., Gerdes, A., 2013. Timing of incremental pluton construction and magmatic activity in a back-arc setting revealed by IDTIMS U/Pb and Hf isotopes on complex zircon grains. Chemical Geology 342, 76-93. doi:10.1016/j.chemgeo.2012.12.011

Baxter, S., Feely, M., 2002. Magma mixing and mingling textures in granitoids: examples from the Galway Granite, Connemara, Ireland. Mineralogy and Petrology 76, 63-74. doi:10.1007/s007100200032

Bea, F., Fershtater, G.B., Montero, P., Smirnov, V.N., Molina, J.F., 2005. Deformation-driven differentiation of granitic magma: the Stepninsk pluton of the Uralides, Russia. Lithos 81, 209233. doi:10.1016/j.lithos.2004.10.004

Béchennec, F., Thiéblemont, D., 2009. Bubry, 349. Notice explicative, Carte géologique de France (1/50 000), Bureau de Recherches Géologiques et Minières.

Béchennec, F., Thiéblemont, D., Audru, J.C., 2006. Notice explicative, Carte géologique de France (1/50 000), Plouay, 348. Bureau de Recherches Géologiques et Minières.

Bernard-Griffiths, J., Peucat, J.J., Sheppard, S., Vidal, P., 1985. Petrogenesis of Hercynian leucogranites from the southern Armorican Massif: contribution of REE and isotopic ( $\mathrm{Sr}, \mathrm{Nd}, \mathrm{Pb}$ and $\mathrm{O}$ ) geochemical data to the study of source rock characteristics and ages. Earth and Planetary Science Letters 74, 235-250. doi:10.1016/0012-821X(85)90024-X

Berthé, D., Choukroune, P., Jegouzo, P., 1979. Orthogneiss, mylonite and non coaxial deformation of granites: the example of the South Armorican Shear Zone. Journal of Structural Geology 1, 3142. doi:10.1016/0191-8141(79)90019-1

Bonin, B., 2004. Do coeval mafic and felsic magmas in post-collisional to within-plate regimes necessarily imply two contrasting, mantle and crustal, sources? A review. Lithos 78, 1-24. doi:10.1016/j.lithos.2004.04.042 
Bos, P., Castaing, C., Clément, J.P., Chantraine, J., Lemeille, F., 1997. Rostrenen, 312. Bureau de Recherches Géologiques et Minières.

Bosse, V., Ballevre, M., Vidal, O., 2002. Ductile Thrusting Recorded by the Garnet Isograd from Blueschist-Facies Metapelites of the Ile de Groix, Armorican Massif, France. Journal of Petrology 43, 485-510. doi:10.1093/petrology/43.3.485

Bosse, V., Féraud, G., Ballèvre, M., Peucat, J.J., Corsini, M., 2005. Rb-Sr and 40Ar/39Ar ages in blueschists from the Ile de Groix (Armorican Massif, France): Implications for closure mechanisms in isotopic systems. Chemical Geology 220, 21-45. doi:10.1016/j.chemgeo.2005.02.019

Bouvier, A., Vervoort, J.D., Patchett, P.J., 2008. The Lu-Hf and Sm-Nd isotopic composition of CHUR: Constraints from unequilibrated chondrites and implications for the bulk composition of terrestrial planets. Earth and Planetary Science Letters 273, 48-57. doi:10.1016/j.epsl.2008.06.010

Brun, J.P., Faccenna, C., 2008. Exhumation of high-pressure rocks driven by slab rollback. Earth and Planetary Science Letters 272, 1-7. doi:10.1016/j.eps1.2008.02.038

Brun, J.P., Guennoc, P., Truffert, C., Vairon, J., 2001. Cadomian tectonics in northern Brittany: a contribution of 3-D crustal-scale modelling. Tectonophysics 331, 229-246. doi:10.1016/S00401951(00)00244-4

Cambeses, A., Garcia-Casco, A., Scarrow, J.H., Montero, P., Pérez-Valera, L.A., Bea, F., 2016. Mineralogical evidence for lamproite magma mixing and storage at mantle depths: Socovos fault lamproites, SE Spain. Lithos 266-267, 182-201. doi:10.1016/j.lithos.2016.10.006

Cao, S., Neubauer, F., 2016. Deep crustal expressions of exhumed strike-slip fault systems: Shear zone initiation on rheological boundaries. Earth-Science Reviews 162, 155-176. doi:10.1016/j.earscirev.2016.09.010

Capdevila, R., 2010. Les granites varisques du Massif Armoricain. Bulletin de la Société Géologique et Minéralogique de Bretagne, 7, 1-52.

Carignan, J., Hild, P., Mevelle, G., Morel, J., Yeghicheyan, D., 2001. Routine Analyses of Trace Elements in Geological Samples using Flow Injection and Low Pressure On-Line Liquid 
Chromatography Coupled to ICP-MS: A Study of Geochemical Reference Materials BR, DRN, UB-N, AN-G and GH. Geostandards Newsletter 25, 187-198. doi:10.1111/j.1751908X.2001.tb00595.x

Caroff, M., Labry, C., Le Gall, B., Authemayou, C., Grosjean, D.B., Guillong, M., 2015. Petrogenesis of late-Variscan high-K alkali-calcic granitoids and calc-alkalic lamprophyres: The AberIldut/North-Ouessant complex, Armorican Massif, France. Lithos 238, 140-155. doi:10.1016/j.lithos.2015.09.025

Caroff, M., Coint, N., Hallot, E., Hamelin, C., Peucat, J.J., Charreteur, G., 2011. The mafic-silicic layered intrusions of Saint-Jean-du-Doigt (France) and North-Guernsey (Channel Islands), Armorican Massif: Gabbro-diorite layering and mafic cumulate-pegmatoid association. Lithos 125, 675-692. doi:10.1016/j.lithos.2011.03.019

Carron, J.P., Kerneizon, M.L.G. de, Nachit, H., 1994. Variscan Granites from Brittany, in: Chantraine, J., Rolet, J., Santallier, D.S., Piqué, A., Keppie, J.D. (Eds.), Pre-Mesozoic Geology in France and Related Areas, IGCP-Project 233. Springer Berlin Heidelberg, pp. 231-239.

Castro, A., Patiño-Douce, A.E., Corretgé, L.G., Rosa, J.D. de la, El-Biad, M., El-Hmidi, H., 1999. Origin of peraluminous granites and granodiorites, Iberian massif, Spain: an experimental test of granite petrogenesis. Contrib. Mineral. Petrol. 135, 255-276. doi:10.1007/s004100050511

Chantraine, J., Carric, G., Dadet, P., Flageollet, J.C., Sagon, J.P., Talbo, H., Mulot, B., 1979. Notice explicative, Carte géologique de France (1/50 000), Moncontour, 279. Bureau de Recherches Géologiques et Minières.

Chantraine, J., Autran, A., Cavelier, C., 2003. Carte géologique de la France à 1/1 000000 6ème édition révisée. Bureau de Recherches Géologiques et Minières.

Chappell, B.W., White, A.J.R., Wyborn, D., 1987. The Importance of Residual Source Material (Restite) in Granite Petrogenesis. Journal of Petrology. 28, 1111-1138. doi:10.1093/petrology/28.6.1111

Charreteur, 2006, Carcterisation géochimique et isotopique (Nd-Sr) des intrusions tardi-hercyniennes de Ploumanac'h et de Saint-Jean du Doigt (Massif armoricain), Master thesis, Université de Rennes 1. 
Clemens, J.D., Stevens, G., 2012. What controls chemical variation in granitic magmas? Lithos 134135, 317-329. doi:10.1016/j.lithos.2012.01.001

Clemens, J.D., Stevens, G., Farina, F., 2011. The enigmatic sources of I-type granites: The peritectic connexion. Lithos 126, 174-181. doi:10.1016/j.lithos.2011.07.004

Conceição, R.V., Green, D.H., 2004. Derivation of potassic (shoshonitic) magmas by decompression melting of phlogopite + pargasite lherzolite. Lithos 72, 209-229. doi:10.1016/j.lithos.2003.09.003

Condamine, P., Médard, E., 2014. Experimental melting of phlogopite-bearing mantle at 1 GPa: Implications for potassic magmatism. Earth and Planetary Science Letters 397, 80-92. doi:10.1016/j.epsl.2014.04.027

Conrad, W.K., Nicholls, I.A., Wall, V.J., 1988. Water-Saturated and -Undersaturated Melting of Metaluminous and Peraluminous Crustal Compositions at $10 \mathrm{~kb}$ : Evidence for the Origin of Silicic Magmas in the Taupo Volcanic Zone, New Zealand, and Other Occurrences. Journal of Petrology. 29, 765-803. doi:10.1093/petrology/29.4.765

Cosca, M., Stunitz, H., Bourgeix, A.L., Lee, J.P., 2011. ${ }^{40} \mathrm{Ar}^{*}$ loss in experimentally deformed muscovite and biotite with implications for ${ }^{40} \mathrm{Ar} /{ }^{39} \mathrm{Ar}$ geochronology of naturally deformed rocks. Geochimica et Cosmochimica Acta 75, 7759-7778. doi:10.1016/j.gca.2011.10.012

Cotten, J., 1975. Etude des mégacristaux du granite de Rostrenen (Massif Armoricain), PhD thesis, Université de Bretagne Occidentale, Brest.

Couzinié, S., Laurent, O., Moyen, J.F., Zeh, A., Bouilhol, P., Villaros, A., 2016. Post-collisional magmatism: Crustal growth not identified by zircon $\mathrm{Hf}-\mathrm{O}$ isotopes. Earth and Planetary Science Letters 456, 182-195. doi:10.1016/j.eps1.2016.09.033

Couzinié, S., Moyen, J.F., Villaros, A., Paquette, J.L., Scarrow, J.H., Marignac, C., 2014. Temporal relationships between $\mathrm{Mg}-\mathrm{K}$ mafic magmatism and catastrophic melting of the Variscan crust in the southern part of Velay Complex (Massif Central, France). Journal of Geosciences 59, 6986. doi:10.3190/jgeosci.155

Dabard, M. P., 1997. Les Formations à cherts carbonés (phtanites) de la chaîne cadomienne; genèse et signification géodynamique; exemple du segment Armoricain. Documents du BRGM. 267 
Dabard, M.P., Loi, A., Peucat, J.J., 1996. Zircon typology combined with Sm-Nd whole-rock isotope analysis to study Brioverian sediments from the Armorican Massif. Sedimentary Geology 101, 243-260. doi:10.1016/0037-0738(95)00068-2

Dadet, P., Bos, P., Chantraine, J., Laville, P., Sagon, J.P., 1988. Notice explicative, Carte géologique de France (1/50 000), Pontivy, 313. Bureau de Recherches Géologiques et Minières.

Debon, F., Le Fort, P., 1988. A cationic classification of common plutonic rocks and their magmatic associations: principles, method, applications. Bulletin de Minéralogie 111 (5), 493-510.

De Saint Blanquat, M., Tikoff, B., Teyssier, C., Vigneresse, J.L., 1998. Transpressional kinematics and magmatic arcs. Geological Society of London Special Publication 135, 327-340. doi:10.1144/GSL.SP.1998.135.01.21

DÍaz-Alvarado, J., Castro, A., Fernández, C., Moreno-Ventas, I., 2011. Assessing Bulk Assimilation in Cordierite-bearing Granitoids from the Central System Batholith, Spain; Experimental, Geochemical and Geochronological Constraints. Journal of Petrology 52, 223-256. doi:10.1093/petrology/egq078

D'Lemos, R.S., Brown, M., Strachan, R.A., 1992. Granite magma generation, ascent and emplacement within a transpressional orogen. Journal of the Geological Society 149, 487-490. doi:10.1144/gsjgs.149.4.0487

Duretz, T., Gerya, T.V., May, D.A., 2011. Numerical modelling of spontaneous slab breakoff and subsequent topographic response. Tectonophysics, TOPO-EUROPE II - From Iberia to the Carpathians and analogues 502, 244-256. doi:10.1016/j.tecto.2010.05.024

Euzen, T., 1993. Pétrogenèse des granites de collision post-épaississement. Le cas des granites crustaux et mantelliques du complexe de Pontivy-Rostrenen (Massif Armoricain, France). Mémoires Géosciences Rennes 51.

Euzen, T., Capdevila, R., 1991. Origine des enclaves microgrenues acides dans le granite peralumineux de Pontivy (Massif Armoricain, France). Comptes Rendus de l'Académie des Sciences, Paris, Série II 313, 413-420.

Evensen, N.M., Hamilton, P.J., O'Nions, R.K., 1978. Rare-earth abundances in chondritic meteorites. Geochimica et Cosmochimica Acta 42, 1199-1212. doi:10.1016/0016-7037(78)90114-X 
Farina, F., Stevens, G., Gerdes, A., Frei, D., 2014. Small-scale Hf isotopic variability in the Peninsula pluton (South Africa): the processes that control inheritance of source 176. Contribution to Mineralogy and Petrology 168, 1-18. doi:10.1007/s00410-014-1065-8

Farina, F., Stevens, G., 2011. Source controlled ${ }^{87} \mathrm{Sr} /{ }^{86} \mathrm{Sr}$ isotope variability in granitic magmas: The inevitable consequence of mineral-scale isotopic disequilibrium in the protolith. Lithos 122 , 189-200. doi:10.1016/j.lithos.2011.01.001

Faure, M., Mézème, E., Duguet, M., Cartier, C., Talbot, J., 2005. Paleozoic tectonic evolution of medioEuropa from the example of the French Massif Central and Massif Armoricain. Journal of Virtual Explorer 19, 1-26 (Electronic Edition).

Faure, M., Leloix, C., Roig, J.Y., 1997. L’Evolution polycyclique de la chaine hercynienne. Bulletin de la Société Géologique de France 168, 695-705.

Gapais, D., 1989. Shear structures within deformed granites: Mechanical and thermal indicators. Geology 17, 1144-1147. doi:10.1130/0091-7613(1989)017<1144:SSWDGM>2.3.CO;2

Gapais, D., Brun, J.P., Gumiaux, C., Cagnard, F., Ruffet, G., Le Carlier de Veslud, C., 2015. Extensional tectonics in the Hercynian Armorican belt (France). An overview. Bulletin de la Société Géologique de France 186, 117-129. doi:10.2113/gssgfbull.186.2-3.117

Gapais, D., Lagarde, J.L., Le Corre, C., Audren, C., Jegouzo, P., Casas Sainz, A., Van Den Driessche, J., 1993. La zone de cisaillement de Quiberon: témoin d'extension de la chaine varisque en Bretagne méridionale au Carbonifère. Comptes Rendus de l'Académie des Sciences, Paris, série II 316, 1123-1129.

Gapais, D., Le Corre, C., 1980. Is the Hercynien belt of Brittany a major shear zone? Nature 288, 574576. doi: $10.1038 / 288574 \mathrm{a} 0$

Georget, Y., 1986, Nature et origine des granites peralumineux à cordiérite et des roches associées. Exemples des granitoides du Massif Armoricain (France): Pétrologie et géochimie, $\mathrm{PhD}$ thesis, Université de Rennes 1.

Gardien, V., Lardeaux, J.M., Ledru, P., Allemand, P., Guillot, S., 1997. Metamorphism during late orogenic extension; insights from the French Variscan belt. Bulletin de la Société Géologique de France 168, 271-286. 
Gerdes, A., Zeh, A., 2006. Combined U-Pb and Hf isotope LA-(MC-)ICP-MS analyses of detrital zircons: Comparison with SHRIMP and new constraints for the provenance and age of an Armorican metasediment in Central Germany. Earth and Planetary Science Letters 249, 47-61. doi:10.1016/j.eps1.2006.06.039

Gilder, S.A., Leloup, P.H., Courtillot, V., Chen, Y., Coe, R.S., Zhao, X., Xiao, W., Halim, N., Cogné, J.P., Zhu, R., 1999. Tectonic evolution of the Tancheng-Lujiang (Tan-Lu) fault via Middle Triassic to Early Cenozoic paleomagnetic data. Journal of Geophysical Research, Solid Earth 104, 15365-15390. doi:10.1029/1999JB900123

Gordon Medaris Jr., L., Ackerman, L., Jelínek, E., Michels, Z.D., Erban, V., Kotková, J., 2015. Depletion, cryptic metasomatism, and modal metasomatism (refertilization) of Variscan lithospheric mantle: Evidence from major elements, trace elements, and Sr-Nd-Os isotopes in a Saxothuringian garnet peridotite. Lithos, High- and ultrahigh-pressure metamorphism from microscopic to orogenic scale 226, 81-97. doi:10.1016/j.lithos.2014.10.007

Gumiaux, C., Judenherc, S., Brun, J.P., Gapais, D., Granet, M., Poupinet, G., 2004b. Restoration of lithosphere-scale wrenching from integrated structural and tomographic data (Hercynian belt of western France). Geology 32, 333-336. doi:10.1130/G20134.2

Gumiaux, C., Gapais, D., Brun, J.P., Chantraine, J., Ruffet, G., 2004a. Tectonic history of the Hercynian Armorican Shear belt (Brittany, France). Geodinamica Acta 17, 289-307. doi:10.3166/ga.17.289-307

Gutiérrez-Alonso, G., Fernández-Suárez, J., Jeffries, T.E., Johnston, S.T., Pastor-Galán, D., Murphy, J.B., Franco, M.P., Gonzalo, J.C., 2011. Diachronous post-orogenic magmatism within a developing orocline in Iberia, European Variscides. Tectonics 30, TC5008. doi:10.1029/2010TC002845

Hanmer, S.K., Corre, C.L., Berthé, D., 1982. The role of Hercynian granites in the deformation and metamorphism of Brioverian and Palaeozoic rocks of Central Brittany. Journal of the Geological Society 139, 85-93. doi:10.1144/gsjgs.139.1.0085

Hans Wedepohl, K., 1995. The composition of the continental crust. Geochimica et Cosmochimica Acta 59, 1217-1232. doi:10.1016/0016-7037(95)00038-2 
Hanson, G.N., 1978. The application of trace elements to the petrogenesis of igneous rocks of granitic composition. Earth and Planetary Science Letters 38, 26-43. doi:10.1016/0012$821 X(78) 90124-3$

Healy, B., Collins, W.J., Richards, S.W., 2004. A hybrid origin for Lachlan S-type granites: the Murrumbidgee Batholith example. Lithos 78, 197-216. doi:10.1016/j.lithos.2004.04.047

Houseman, G.A., McKenzie, D.P., Molnar, P., 1981. Convective instability of a thickened boundary layer and its relevance for the thermal evolution of continental convergent belts. Journal of Geophysical Research Solid Earth 86, 6115-6132. doi:10.1029/JB086iB07p06115

Huppert, H.E., Sparks, R.S.J., 1988. The Generation of Granitic Magmas by Intrusion of Basalt into Continental Crust. Journal of Petrology 29, 599-624. doi:10.1093/petrology/29.3.599

Hutton, D.H.W., 1988. Granite emplacement mechanisms and tectonic controls: inferences from deformation studies. Earth and Environemental Science Transaction of the Royal Society Edinburg 79, 245-255. doi:10.1017/S0263593300014255

Hutton, D.H.W., Reavy, R.J., 1992. Strike-slip tectonics and granite petrogenesis. Tectonics 11, 960967. doi:10.1029/92TC00336

Instituto Geológico y Minero de España (IGME), 2015. 1000000 Geological map of Portugal and Spain.

Huw Davies, J., von Blanckenburg, F., 1995. Slab breakoff: A model of lithosphere detachment and its test in the magmatism and deformation of collisional orogens. Earth and Planetary Science Letters 129, 85-102. doi:10.1016/0012-821X(94)00237-S

Janoušek, V., Holub, F.V., 2007. The causal link between HP-HT metamorphism and ultrapotassic magmatism in collisional orogens: case study from the Moldanubian Zone of the Bohemian Massif. Proceeding of the Geologist Association 118, 75-86. doi:10.1016/S00167878(07)80049-6

Jégouzo, P., 1980. The South Armorican Shear Zone. Journal of Structural Geology 2, 39-47. doi:10.1016/0191-8141(80)90032-2 
Jones, K.A., Brown, M., 1990. High-temperature “clockwise"P-T paths and melting in the development of regional migmatites: an example from southern Brittany, France. Journal of Metamorphic Geology 8, 551-578. doi:10.1111/j.1525-1314.1990.tb00486.x

Judenherc, S., Granet, M., Brun, J.P., Poupinet, G., 2003. The Hercynian collision in the Armorican Massif: evidence of different lithospheric domains inferred from seismic tomography and anisotropy. Bulletin de la Société Géologique de France 174, 45-57.

Kretz, R., 1983. Symbols for rock-forming minerals. American Mineralogist 68, 277-279.

Laumonier, M., Scaillet, B., Arbaret, L., Andújar, J., Champallier, R., 2015. Experimental mixing of hydrous magmas. Chemical Geology 418, 158-170. doi:10.1016/j.chemgeo.2015.10.031

Laumonier, M., Scaillet, B., Arbaret, L., Champallier, R., 2014. Experimental simulation of magma mixing at high pressure. Lithos 196-197, 281-300. doi:10.1016/j.lithos.2014.02.016

Laurent, O., Couzinié, S., Zeh, A., Vanderhaeghe, O., Moyen, J.F., Villaros, A., Gardien, V., ChelleMichou, C., 2017. Protracted, coeval crust and mantle melting during Variscan late-orogenic evolution: $\mathrm{U}-\mathrm{Pb}$ dating in the eastern French Massif Central. International Journal of Earth Sciences (Geol Rundsch) 1-31. doi:10.1007/s00531-016-1434-9

Laurent, O., Zeh, A., 2015. A linear Hf isotope-age array despite different granitoid sources and complex Archean geodynamics: Example from the Pietersburg block (South Africa). Earth and Planetary Science Letters 430, 326-338. doi:10.1016/j.eps1.2015.08.028.

Le Hébel, F., Vidal, O., Kienast, J.R., Gapais, D., 2002. Les « Porphyroïdes » de Bretagne méridionale : une unité de HP-BT dans la chaîne hercynienne. Comptes Rendus Geoscience 334, 205-211. doi:10.1016/S1631-0713(02)01746-7

Le Gall, B., Authemayou, C., Ehrhold, A., Paquette, J.L., Bussien, D., Chazot, G., Aouizerat, A., Pastol, Y., 2014. LiDAR offshore structural mapping and U/Pb zircon/monazite dating of Variscan strain in the Leon metamorphic domain, NW Brittany. Tectonophysics 630, 236-250. doi:10.1016/j.tecto.2014.05.026

Leake, B.E., 1978. Nomenclature of amphiboles. Canadian Mineralogist 16, 501-520. 
Leloup, P.H., Ricard, Y., Battaglia, J., Lacassin, R., 1999. Shear heating in continental strike-slip shear zones: model and field examples. Geophysical Journal International 136, 19-40. doi:10.1046/j.1365-246X.1999.00683.x

Lemarchand, J., Boulvais, P., Gaboriau, M., Boiron, M.C., Tartèse, R., Cokkinos, M., Bonnet, S., Jégouzo, P., 2012. Giant quartz vein formation and high-elevation meteoric fluid infiltration into the South Armorican Shear Zone: geological, fluid inclusion and stable isotope evidence. Journal of the Geological Society 169, 17-27. doi:10.1144/0016-76492010-186

Liew, T.C., Hofmann, A.W., 1988. Precambrian crustal components, plutonic associations, plate environment of the Hercynian Fold Belt of central Europe: indications from a Nd and Sr isotopic study. Contributions to Mineralogy and Petrology 98, 129-138.

Ludwig, K.R., 2001. Isoplot/Ex Version 2.49. A Geochronological Toolkit for Microsoft Excel. Berkeley Geochronology Center, Special Publication vol. 1a, pp. 1-55.

Malavieille, J., Guihot, P., Costa, S., Lardeaux, J.M., Gardien, V., 1990. Collapse of the thickened Variscan crust in the French Massif Central: Mont Pilat extensional shear zone and St. Etienne Late Carboniferous basin. Tectonophysics 177, 139-149. doi:10.1016/0040-1951(90)90278-G

Martínez Catalán, J.R., Rubio Pascual, F.J., Díez Montes, A., Díez Fernández, R.D., Gómez Barreiro, J., Dias Da Silva, Í., González Clavijo, E.G., Ayarza, P., Alcock, J.E., 2014. The late Variscan HT/LP metamorphic event in NW and Central Iberia: relationships to crustal thickening, extension, orocline development and crustal evolution. Geological Society, London, Special Publications 405, 225-247. doi:10.1144/SP405.1

McDonough, W.F., Sun, S.s., 1995. The composition of the Earth. Chemical Geology, Chemical Evolution of the Mantle 120, 223-253. doi:10.1016/0009-2541(94)00140-4

Michard, A., Gurriet, P., Soudant, M., Albarede, F., 1985. Nd isotopes in French Phanerozoic shales: external vs. internal aspects of crustal evolution. Geochimica et Cosmochimica Acta 49, 601610. doi:10.1016/0016-7037(85)90051-1

Miller, C.F., Stoddard, E.F., Bradfish, L.J., Dollase, W.A., 1981. Composition of plutonic muscovite; genetic implications. Canadian Mineralogist 19, 25-34. 
Molina, J.F., Montero, P., Bea, F., Scarrow, J.H., 2012. Anomalous xenocryst dispersion during tonalite-granodiorite crystal mush hybridization in the mid crust: Mineralogical and geochemical evidence from Variscan appinites (Avila Batholith, Central Iberia). Lithos 153, 224-242. doi:10.1016/j.lithos.2012.03.021

Molnar, P., Houseman, G.A., 2004. The effects of buoyant crust on the gravitational instability of thickened mantle lithosphere at zones of intracontinental convergence. Geophysical Journal International 158, 1134-1150. doi:10.1111/j.1365-246X.2004.02312.x

Montel, J.M., Vielzeuf, D., 1997. Partial melting of metagreywackes, Part II. Compositions of minerals and melts. Contribution to Mineralogy Petrology 128, 176-196. doi:10.1007/s004100050302

Morfin, S., Sawyer, E.W., Bandyayera, D., 2014. The geochemical signature of a felsic injection complex in the continental crust: Opinaca Subprovince, Quebec. Lithos 196-197, 339-355. doi:10.1016/j.lithos.2014.03.004

Moyen, J.F., Laurent, O., Chelle-Michou, C., Couzinié, S., Vanderhaeghe, O., Zeh, A., Villaros, A., Gardien, V., 2016. Collision vs. subduction-related magmatism: two contrasting ways of granite formation and implications for crustal growth. Lithos. doi:10.1016/j.lithos.2016.09.018

Nachit, H., Razafimahefa, N., Stussi, J.M., Carron, J.P., 1985. Composition chimique des biotites et typologie magmatique des granitoïdes. Comptes Rendus de l'Académie des Sciences, Paris Série II 301, 813-818.

Norris, R.J., Cooper, A.F., 2000. Late Quaternary slip rates and slip partitioning on the Alpine Fault, New Zealand. Journal of Structural Geology 23, 507-520. doi:10.1016/S0191-8141(00)00122$\mathrm{X}$

Patiño-Douce, A.E., 1999. What do experiments tell us about the relative contributions of crust and mantle to the origin of granitic magmas? Geological Society of London Special Publication 168, 55-75. doi:10.1144/GSL.SP.1999.168.01.05

Patiño-Douce, A.E., 1997. Generation of metaluminous A-type granites by low-pressure melting of calcalkaline granitoids. Geology 25, 743-746. doi:10.1130/00917613(1997)025<0743:GOMATG>2.3.CO;2 
Patiño-Douce, A.E., Harris, N., 1998. Experimental Constraints on Himalayan Anatexis. Journal of Petrology 39, 689-710. doi:10.1093/petroj/39.4.689

Patiño-Douce, A.E., Beard, J.S., 1995. Dehydration-melting of Biotite Gneiss and Quartz Amphibolite from 3 to 15 kbar. Journal of Petrology 36, 707-738. doi:10.1093/petrology/36.3.707

Patiño-Douce, A.E., Johnston, A.D., 1991. Phase equilibria and melt productivity in the pelitic system: implications for the origin of peraluminous granitoids and aluminous granulites. Contribution to Mineralogy and Petrology 107, 202-218. doi:10.1007/BF00310707

Petford, N., Gallagher, K., 2001. Partial melting of mafic (amphibolitic) lower crust by periodic influx of basaltic magma. Earth and Planetary Science Letters 193, 483-499. doi:10.1016/S0012$821 \mathrm{X}(01) 00481-2$

Peucat, J.J., Auvray, B., Hirbec, Y., Calvez, J.Y., 1984. Granites et cisaillements hercyniens dans le Nord du Massif Armoricain; geochronologie Rb-Sr. Bulletin de la Société Géologique de France S7-XXVI, 1365-1373. doi:10.2113/gssgfbull.S7-XXVI.6.1365

Peucat, J. J., Charlot, R., Mifdal, A., Chantraine, J., Autran, A., 1979. Définition géochronologique de la phase bretonne en Bretagne centrale. Etude $\mathrm{Rb} / \mathrm{Sr}$ de granites du domaine centre armoricain. Bulletin du BRGM, 1(4), 349-356.

Pirajno, F., 2010. Intracontinental strike-slip faults, associated magmatism, mineral systems and mantle dynamics: examples from NW China and Altay-Sayan (Siberia). Journal of Geodynamic, Supercontinents and Crustal Evolution 50, 325-346. doi:10.1016/j.jog.2010.01.018

Rocchi, S., Storti, F., Vincenzo, G.D., Rossetti, F., 2003. Intraplate strike-slip tectonics as an alternative to mantle plume activity for the Cenozoic rift magmatism in the Ross Sea region, Antarctica. Geological Society of London Special Publication 210, 145-158. doi:10.1144/GSL.SP.2003.210.01.09

Rudnick, R.L., Gao, S., 2003. Composition of the Continental Crust. Treatise on Geochemistry 3, 659. doi:10.1016/B0-08-043751-6/03016-4

Scaillet, B., Holtz, F., Pichavant, M., 1998. Phase equilibrium constraints on the viscosity of silicic magmas: 1. Volcanic-plutonic comparison. Journal of Geophysical Research 103, $27257-$ 27266. doi:10.1029/98JB02469 
Scarrow, J.H., Molina, J.F., Bea, F., Montero, P., 2009. Within-plate calc-alkaline rocks: Insights from alkaline mafic magma-peraluminous crustal melt hybrid appinites of the Central Iberian Variscan continental collision. Lithos 110, 50-64. doi:10.1016/j.lithos.2008.12.007

Scherer, E., Münker, C., Mezger, K., 2001. Calibration of the Lutetium-Hafnium Clock. Science 293, 683-687. doi:10.1126/science.1061372

Shand, S., 1943. Eruptive Rocks. Their genesis, composition, classification, and their relations to oredeposits 2. Wiley, New York, p. 444.

Shaw, D., 1968. A review of K-Rb fractionation trends by covariance analysis. Geochimica et Cosmochimica Acta 32, 573-601. doi:10.1016/0016-7037(68)90050-1

Sibson, R.H., 1987. Earthquake rupturing as a mineralizing agent in hydrothermal systems. Geology 15 , 701-704. doi:10.1130/0091-7613(1987)15<701:ERAAMA>2.0.CO;2

Simons, B., Shail, R.K., Andersen, J.C.Ø., 2016. The petrogenesis of the Early Permian Variscan granites of the Cornubian Batholith: Lower plate post-collisional peraluminous magmatism in the Rhenohercynian Zone of SW England. Lithos 260, 76-94. doi:10.1016/j.lithos.2016.05.01

Söderlund, U., Patchett, P.J., Vervoort, J.D., Isachsen, C.E., 2004. The ${ }^{176} \mathrm{Lu}$ decay constant determined by $\mathrm{Lu}-\mathrm{Hf}$ and $\mathrm{U}-\mathrm{Pb}$ isotope systematics of Precambrian mafic intrusions. Earth and Planetary Science Letters 219, 311-324. doi:10.1016/S0012-821X(04)00012-3

Spicer, E.M., Stevens, G., Buick, I.S., 2004. The low-pressure partial-melting behaviour of natural boron-bearing metapelites from the Mt. Stafford area, central Australia. Contribution to Mineralogy and Petrology 148, 160-179. doi:10.1007/s00410-004-0577-z

Stevens, G., Villaros, A., Moyen, J.F., 2007. Selective peritectic garnet entrainment as the origin of geochemical diversity in S-type granites. Geology 35, 9-12. doi:10.1130/G22959A.1

Storti, F., Holdsworth, R.E., Salvini, F., 2003. Intraplate strike-slip deformation belts. Geological Society of London Special Publication 210, 1-14. doi:10.1144/GSL.SP.2003.210.01.01

Strong, D.F., Hanmer, S.K., 1981. The leucogranites of southern Brittany; origin by faulting, frictional heating, fluid flux and fractional melting. Canadian Mineralogist 19, 163-176.

Sylvester, A.G., 1988. Strike-slip faults. Geological Society America Bulletin 100, 1666-1703. doi:10.1130/0016-7606(1988)100<1666:SSF>2.3.CO;2 
Tartèse, R., Boulvais, P., 2010. Differentiation of peraluminous leucogranites "en route" to the surface. Lithos 114, 353-368. doi:10.1016/j.lithos.2009.09.011

Tartèse, R., Boulvais, P., Poujol, M., Chevalier, T., Paquette, J.L., Ireland, T.R., Deloule, E., 2012. Mylonites of the South Armorican Shear Zone: Insights for crustal-scale fluid flow and waterrock interaction processes. Journal of Geodynamics 56-57, 86-107. doi:10.1016/j.jog.2011.05.003

Tartèse, R., Ruffet, G., Poujol, M., Boulvais, P., Ireland, T.R., 2011b. Simultaneous resetting of the muscovite K-Ar and monazite U-Pb geochronometers: a story of fluids. Terra Nova 23, 390398. doi:10.1111/j.1365-3121.2011.01024.x

Tartèse, R., Poujol, M., Ruffet, G., Boulvais, P., Yamato, P., Košler, J., 2011a. New U-Pb zircon and ${ }^{40} \mathrm{Ar} /{ }^{39} \mathrm{Ar}$ muscovite age constraints on the emplacement of the Lizio syn-tectonic granite (Armorican Massif, France). Comptes Rendus Geoscience 343, 443-453. doi:10.1016/j.crte.2011.07.005

Taylor, S.R., McLennan, S.M., 1985. The continental crust: its composition and evolution. Blackwell, Oxford, $312 \mathrm{pp}$.

Thibault, Y., Edgar, A.D., Lloyd, F.E., 1992. Experimental investigation of melts from a carbonated phlogopite lherzolite: implications for metasomatism in the continental lithospheric mantle. American Mineralogist 77, 784-794.

Turpin, L., Velde, D., Pinte, G., 1988. Geochemical comparison between minettes and kersantites from the Western European Hercynian orogen: trace element and $\mathrm{Pb}-\mathrm{Sr}-\mathrm{Nd}$ isotope constraints on their origin. Earth and Planetary Science Letters 87, 73-86. doi:10.1016/0012-821X(88)900659

Turrillot, P., Augier, R., Faure, M., 2009. The top-to-the-southeast Sarzeau shear zone and its place in the late-orogenic extensional tectonics of southern Armorica. Bulletin de la Société Géologique de France 180, 247-261. doi:10.2113/gssgfbull.180.3.247

van Hunen, J., Allen, M.B., 2011. Continental collision and slab break-off: A comparison of 3-D numerical models with observations. Earth and Planetary Science Letters 302, 27-37. doi:10.1016/j.eps1.2010.11.035 
Vanderhaeghe, O., Duchêne, S., 2010. Crustal-scale mass transfer, geotherm and topography at convergent plate boundaries. Terra Nova 22, 315-323. doi:10.1111/j.1365-3121.2010.00952.x

Vanderhaeghe, O., Teyssier, C., 2001. Crustal-scale rheological transitions during late-orogenic collapse. Tectonophysics 335, 211-228. doi:10.1016/S0040-1951(01)00053-1

Vauchez, A., Tommasi, A., 2003. Wrench faults down to the asthenosphere: geological and geophysical evidence and thermomechanical effects. Geological Society of London Special Publication 210, 15-34. doi:10.1144/GSL.SP.2003.210.01.02

Vermeesch, P., 2012. On the visualisation of detrital age distributions. Chemical Geology, v.312-313, 190-194, doi: 10.1016/j.chemgeo.2012.04.0210.

Vielzeuf, D., Holloway, J.R., 1988. Experimental determination of the fluid-absent melting relations in the pelitic system. Contribution to Mineralogy and Petrology 98, 257-276. doi:10.1007/BF00375178

Vigneresse, J.L., 1999. Intrusion level of granitic massifs along the Hercynian belt: balancing the eroded crust. Tectonophysics 307, 277-295. doi:10.1016/S0040-1951(99)00104-3

Vigneresse, J.L., Brun, J.P., 1983. Les leucogranites armoricains marqueurs de la déformation régionale; apport de la gravimétrie. Bulletin de la société géologique de France 7, 357-366. doi:10.2113/gssgfbull.S7-XXV.3.357

Villaros, A., Buick, I.S., Stevens, G., 2011. Isotopic variations in S-type granites: an inheritance from a heterogeneous source? Contribution to Mineralogy and Petrology 163, 243-257. doi:10.1007/s00410-011-0673-9

Villaros, A., Stevens, G., Moyen, J.F., Buick, I.S., 2009. The trace element compositions of S-type granites: evidence for disequilibrium melting and accessory phase entrainment in the source. Contribution to Mineralogy and Petrology 158, 543-561. doi:10.1007/s00410-009-0396-3

von Blanckenburg, F., Davies, J.H., 1995. Slab breakoff: A model for syncollisional magmatism and tectonics in the Alps. Tectonics 14, 120-131. doi:10.1029/94TC02051

Woodhead, J.D., Hergt, J.M., 2005. A Preliminary Appraisal of Seven Natural Zircon Reference Materials for In Situ Hf Isotope Determination. Geostandards and Geoanalytical Research 29, 183-195. doi:10.1111/j.1751-908X.2005.tb00891.x 
Yoshikawa, M., Kawamoto, T., Shibata, T., Yamamoto, J., 2010. Geochemical and Sr-Nd isotopic characteristics and pressure-temperature estimates of mantle xenoliths from the French Massif Central: evidence for melting and multiple metasomatism by silicate-rich carbonatite and asthenospheric melts. Geological Society of London Special Publication 337, 153-175. doi:10.1144/SP337.8 


\section{Figure captions}

Figure 1: (a) Main structural domains of the Armorican Massif. (b) General geological map of the Armorican Massif showing the four types of late Carboniferous granites according to Capdevila (2010). The map is modified from Chantraine et al. (2003) and Gapais et al. (2015). NASZ: North Armorican Shear Zone; NBSASZ: Northern Branch of the South Armorican Shear Zone. SBSASZ: Southern Branch of the South Armorican Shear Zone. Fe-K granites: ferro-potassic granites. Mg-K granites: magnesio-potassic granites. Calk-alk granites: calco - alkaline granites. Mineral abbreviations according to Kretz (1983).

Figure 2: (a) Geological map of the Pontivy-Rostrenen granitic complex showing the different magmatic units, the magmatic foliation and the country rock metamorphism. Samples from this study and from previous studies are localized on the map. The map is modified from Euzen (1993) and from the 1/50000 BRGM geological maps of Pontivy (Dadet et al., 1988), Rostrenen (Bos et al., 1997), Plouay (Béchennec et al., 2006) and Bubry (Béchennec and Thiéblemont, 2009). (b) Cross-section of the Pontivy-Rostrenen granitic complex modified from Vigneresse (1999). Mineral abbreviations from Kretz (1983).

Figure 3: Pictures representative of the Pontivy (a-b) and the Rostrenen (c-d) granitoids. (a) Porphyritic leucogranite (PONT-1). (b) equigranular leucogranite. (c) Porphyritic monzogranite with a mafic enclave (ME). (d) Mingling features at the contact between a porphyritic monzogranite (Mgr) and a quartz monzodiorite (Mdr). The scale bar represents $5 \mathrm{~cm}$.

Figure 4: Thin-section photomicrographs of samples representative of the Pontivy (a-b) and Rostrenen granitoids (c-d). (a): PONT-27: Ms > Bt leucogranite with two generations of muscovite (Ms1: primary muscovite; Ms2: secondary muscovite). (b) PONT-12: Ms > Bt leucogranite. (c) PONT-22: Bt monzogranite. (d) PONT-23: Bt > Act quartz monzodiorite with an ocelli quartz (Qtz) surrounded by amphibole (Act). Mineral abbreviations according to Kretz (1983). 
Figure 5: Chemical compositions of plagioclase, biotite and muscovite in the Pontivy and Rostrenen granitoids. (a) Triangular classification of the plagioclase. (b) $\mathrm{Al}_{\text {tot }}$ versus $\mathrm{Mg}$ plot for biotite. The fields are from Nachit et al., 1985. (c) Ternary Ti-Na-Mg diagram for muscovite and chemical maps of the Ti distribution in muscovite for one of the Ms late equigranular leucogranite (PONT-21) and a Ms equigranular leucogranite (PONT-14). The primary and secondary fields of muscovite are from Miller et al. (1981). In the figure, "small" refers to small muscovite inside the foliation planes.

Figure 6: In all of the diagrams, symbols in light colors represent the Pontivy-Rostrenen granitoid samples from the literature (Cotten, 1975; Euzen, 1993; Béchennec et al., 2006, 2009; Tartèse et al., 2012) while the symbols in darker colors represent the samples from this study. (a) Shand (1943) diagram $\left[\mathrm{A} / \mathrm{CNK}=\mathrm{Al}_{2} \mathrm{O}_{3} /\left(\mathrm{CaO}+\mathrm{Na}_{2} \mathrm{O}+\mathrm{K}_{2} \mathrm{O}\right) ; \mathrm{A} / \mathrm{NK}=\mathrm{Al}_{2} \mathrm{O}_{3} /\left(\mathrm{Na}_{2} \mathrm{O}+\mathrm{K}_{2} \mathrm{O}\right) ;\right.$ molar proportions $]$. (b-c) Q-P and A-B mineral-chemical diagrams (after Debon and Le Fort, 1988). The melt compositions produced by experimental partial melting are from Vielzeuf and Holloway (1988), Patiño-Douce and Johnston (1991), Patiño-Douce and Harris (1998), Montel and Vielzeuf (1997) and Spicer et al. (2004) for sediments, Castro et al. (1999) for peraluminous igneous rocks, Conrad et al. (1988), Patiño-Douce and Beard (1995) and Patiño-Douce (1997) for metaluminous igneous rocks, Thibault et al. (1992) Conceição and Green (2004) and Condamine and Médard (2014) for phlogopite-bearing lherzolites. The fields in dashed lines delimitate the location of common igneous rock: gr = granite, ad = adamellite (monzogranite), $\mathrm{gd}=$ granodiorite, to $=$ tonalite, $\mathrm{sq}=$ quartz syenite, $\mathrm{mzq}=$ quartz monzonite, $\mathrm{mzdq}=$ quartz monzodiorite, $\mathrm{s}=$ syenite, $\mathrm{mz}=$ monzonite, and $\mathrm{mzgo}=$ monzogabbro. $\mathrm{Q}$ and $\mathrm{P}$ parameters are expressed in molar proportion multiplied by 1000. (d) $\mathrm{AFM}\left(\mathrm{Na}_{2} \mathrm{O}+\mathrm{K}_{2} \mathrm{O}-\mathrm{FeO}+\mathrm{MnO}-\mathrm{MgO}\right.$; wt.\%). The composition of Variscan post-collisional mafic magmatic rocks (Couzinié et al., 2016 and reference therein) are reported for comparison. Ca: calco-alkaline; Alk: alkaline; Th: tholeiitic. 
Figure 7: (a) Harker diagrams for the Pontivy-Rostrenen granitoid samples. (b) Harker diagram for the leucogranitic samples. The dashed-line boxes delimit the samples in the range $70.8-72.3 \mathrm{wt} . \%$ $\mathrm{SiO}_{2}$ which are reported in Figure 13. (c) Selected trace element versus $\mathrm{SiO}_{2}$ diagrams for the PontivyRostrenen granitoid samples. In (a) and (c), the grey dashed-line with crosses illustrates the mixing model between the composition of the average high-SiO${ }_{2}(>70 \mathrm{wt} . \%)$ monzogranites samples and the average composition of low- $\mathrm{SiO}_{2}(\leq 55 \mathrm{wt} . \%)$ quartz monzodiorite samples. The crosses represent increments of $10 \%$ of magma assimilation. In (a) and (b) the black and grey arrows represent $20 \mathrm{wt} . \%$ of the fractional crystallization or the entrainment of different minerals. Parent compositions used in the modeling are the average of high- $\mathrm{SiO}_{2}(>70 \mathrm{wt} . \%)$ monzogranites samples, low- $\mathrm{SiO}_{2}(\leq 55 \mathrm{wt} . \%)$ quartz monzodiorite samples and the low-SiO 2 PONT-25 equigranular leucogranite sample. In the $\mathrm{Zr}$ versus $\mathrm{SiO}_{2}$ and $\mathrm{La}$ versus $\mathrm{SiO}_{2}$ diagrams, the arrows representing the fractional crystallization or the entrainment of zircon (Zrn) and monazite (Mnz) are theoretical. Sed represents the assimilation of 20 wt.\% of the mean composition of the Brioverian to Paleozoic sediments from central Brittany (Georget, 1986). The details of the AFC modeling (assimilation - fractional crystallization) for the quartz monzodiorites as well as the peritectic mineral entrainment or magma mixing modeling for the monzogranites and fractional crystallization modeling (FC) for the leucogranites are provided in Supplementary file 5. Late equ. leucogranite: late equigranular leucogranite.

Figure 8: (a) REE patterns normalized to chondrite (Evensen et al., 1978) and (b) multi-element diagram normalized to the primitive mantle (McDonough and Sun, 1995) for the granitoid samples from the Pontivy-Rostrenen complex. In (b), the average compositions of the samples are reported with the average continental crust values (Rudnick and Gao, 2004) for comparison.

Figure 9: (a) Initial $\mathrm{Sr}$ and $\mathrm{Nd}$ isotope compositions of the Pontivy-Rostrenen granitoid samples. The analyses in a light color are from Euzen (1993) and Peucat et al. (1979). The vertical bars represent the $\varepsilon N d$ compositions of the Ordovician acid metavolcanics (Vendée Porphyroids, Ballèvre et al., 2012), 
Ordovician metagranitoids (this study), Brioverian sediments (Dabard et al., 1996; Dabard, 1997) and Ordovician to Devonian sediments (Michard et al., 1985) from the Armorican Massif. Isotopic compositions of other Late Carboniferous igneous rocks from the Armorican Massif (Lizio and Questembert leucogranites: Tartèse and Boulvais, 2010; Guérande leucogranite: Ballouard et al., 2015; Ploumanac'h intrusion: Charreteur, 2006) as well as Variscan post-collisional mafic magmatic rocks (PCMMR; Turpin et al., 1988; Molina et al., 2012; Moyen et al., 2016) are also reported for comparison. All of the $\mathrm{I}_{\mathrm{Sr}}$ and $\varepsilon \mathrm{Nd}$ values have been calculated for an age of $315 \mathrm{Ma}$. (b) $\mathrm{I}_{\mathrm{Sr}}(315 \mathrm{Ma})$ versus $\mathrm{SiO}_{2}$ diagram for the Pontivy-Rostrenen granitoid samples. The dashed-line with gray crosses represents the mixing model between the monzogranite sample PONT-24 and the quartz monzodiorite sample PONT-7. Crosses represent increment of $10 \%$ of magma assimilation.

Figure 10: Selected (a-d) cathodoluminescence and (e) BSE image of zircon grains. White dashed-line circles represent the location of the U-Pb LA-ICP-MS analyses with the corresponding ${ }^{206} \mathrm{~Pb} /{ }^{238} \mathrm{U}$ ages in Ma. Yellow zones represent the location of the Hf isotopic LA-MC-ICP-MS analyses with the corresponding $\varepsilon \mathrm{Hf}(\mathrm{t})$ values. The white bar represents $100 \mu \mathrm{m}$. Late equ. Leucogranite: late equigranular leucogranite.

Figure 11: (a-c, e-f) Tera-Wasserburg diagram displaying the analyses (degree of concordance between 90 and $110 \%$ ) performed on zircon extracted from the granitoid samples from the PontivyRostrenen complex. The gray ellipses represent inherited zircon and the dashed-line ellipses represent zircon that experienced either a $\mathrm{Pb}$-loss or a gain in common $\mathrm{Pb}$. Black ellipses represent the analyses used for the calculation of the concordia ages. \#: ${ }^{207} \mathrm{~Pb} /{ }^{206} \mathrm{~Pb}$ errors at $1 \sigma$. In the diagrams, error ellipses

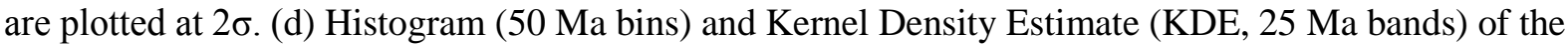
$\mathrm{U}-\mathrm{Pb}$ dates obtained on inherited zircon grains from the leucogranite and monzogranite samples, generated using the DensityPlotter software (Vermeesch. 2012). ${ }^{206} \mathrm{~Pb} /{ }^{238} \mathrm{U}$ dates were used for zircon 
with a ${ }^{206} \mathrm{~Pb} /{ }^{207} \mathrm{~Pb}$ date $<1.0 \mathrm{Ga}$ whereas ${ }^{206} \mathrm{~Pb} /{ }^{207} \mathrm{~Pb}$ dates were used for zircon with a ${ }^{206} \mathrm{~Pb} /{ }^{207} \mathrm{~Pb}$ date $>1.0 \mathrm{Ga}$

Figure 12: (a) diagram showing the $\varepsilon \mathrm{Hf}(\mathrm{t})$ values of magmatic zircon grains versus the $\mathrm{SiO}_{2}$ wholerock content of the granitoid samples from the Pontivy-Rostrenen complex. (b) $\varepsilon \mathrm{Hf}(\mathrm{t})$ versus U-Pb ages for magmatic and inherited zircon grains from the Pontivy-Rostrenen complex leucogranitic samples. The crustal evolution trend was calculated using a ${ }^{176} \mathrm{Lu} /{ }^{177} \mathrm{Hf}$ ratio of 0.0113 (Taylor and McLennan, 1985; Hans Wedepohl, 1995).

Figure 13: Maps displaying the $\mathrm{K}_{2} \mathrm{O}, \mathrm{CaO}$ and $\mathrm{Na}_{2} \mathrm{O}$ contents of the low- $\mathrm{SiO}_{2}(70.8-72.3$ wt.\%) leucogranitic samples.

Figure 14: Schematic cross-section of the Armorican Massif ca. 320 - 310 Ma ago. The colored tails below the intrusions represent feeding dikes. References for $\varepsilon \mathrm{Nd}(315 \mathrm{Ma})$ values are provided in the caption for Figure 9. The cross-section is localized in Figure 15. NASZ: North Armorican Shear Zone, SASZ: South Armorican Shear Zone. See text for details.

Figure 15: Schematic representation of the western part of the European Variscan belt localizing the main terranes and oceanic sutures (modified from Ballèvre et al., 2009, 2013) and showing the distribution of the Variscan granitoids. The granitoids typology is based on the 1:1000000 Geological maps of Portugal and Spain (IGME, 2015) and France (Chantraine et al., 2003). Zones: OMZ, OssaMorena; CIZ, Central Iberian; GTMZ, Galicia-Trás-os-Montes; WALZ, West Asturian-Leonese; CZ, Cantabrian. Shear zones: CCSZ: Coimbra-Córdoba; NBSASZ, Northern branch of the South 
Armorican; SBSASZ, Southern branch of the South Armorican; NASZ: North Armorican. NEF: Nortsur-Erdre fault.GMC: Galicia - Massif Central.

Table 1: GPS coordinates and simplified petrographic description of the Pontivy-Rostrenen granitoid samples. The description and coordinates of Early Paleozoic metagranitoid samples used for the additional Sm-Nd analyses are also reported.

Table 2: Whole-rock chemical composition of the Pontivy-Rostrenen granitoid samples.

Table 3: Rb-Sr and Sm-Nd whole rock data for the Pontivy-Rostrenen granitoids. Additional Sm-Nd analyses of some Early Paleozoic metagranitoids are also reported. Rb concentrations have been obtained by ICP-MS whereas other concentrations have been obtained by ID-TIMS. 


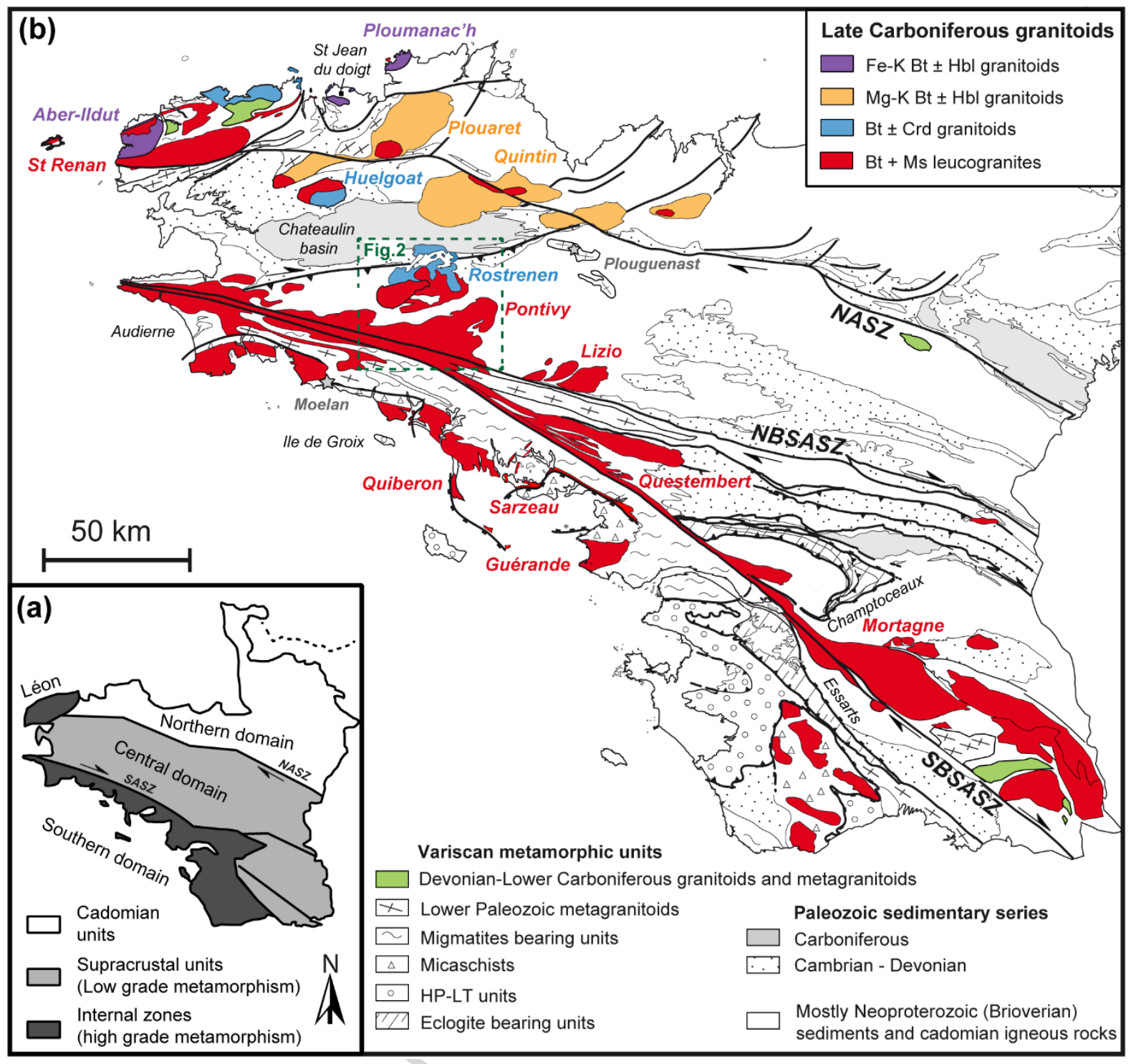

Figure 1 


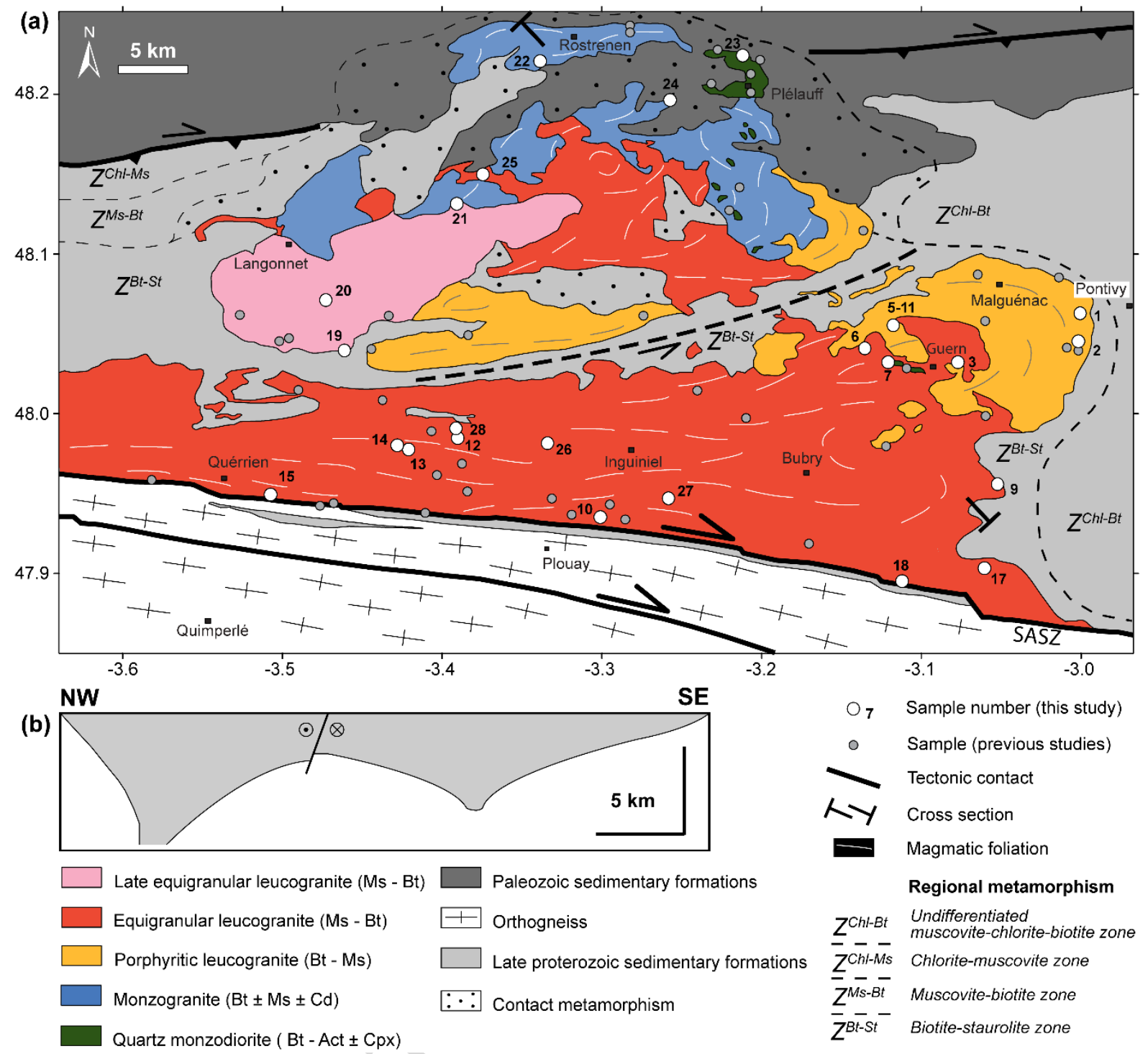

Figure 2 

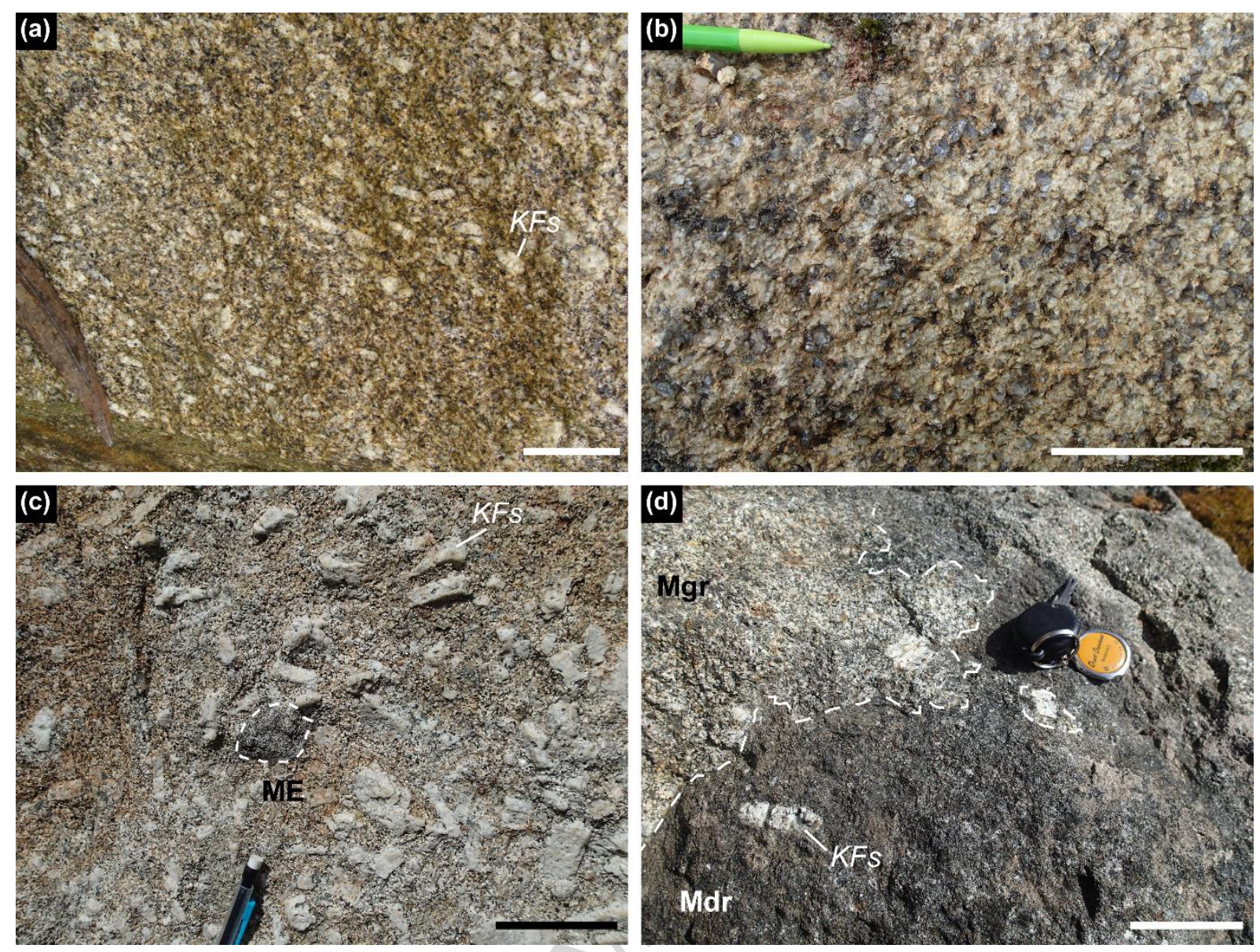

Figure 3 

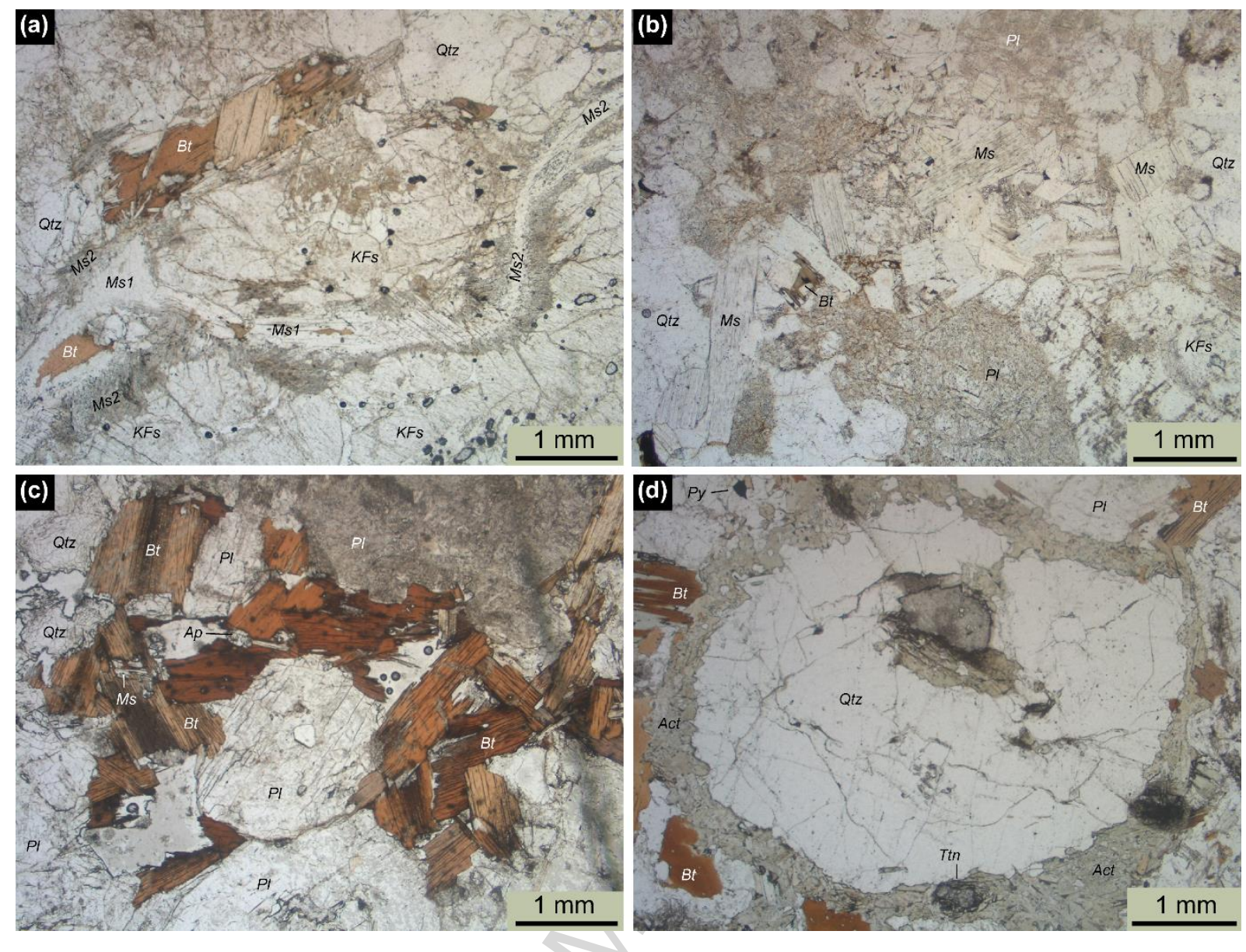

Figure 4

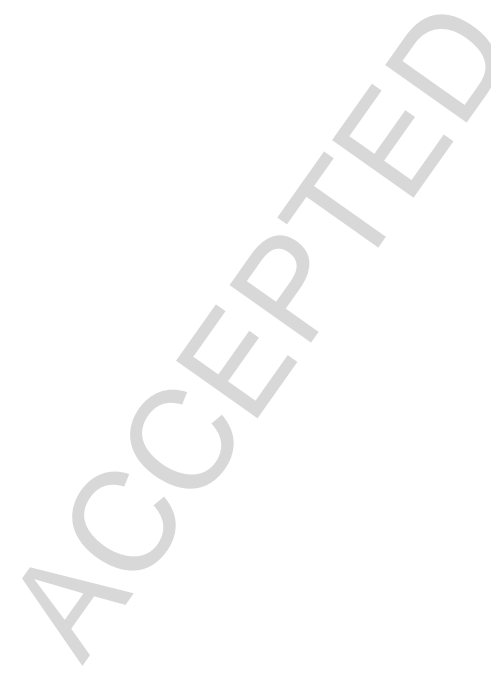




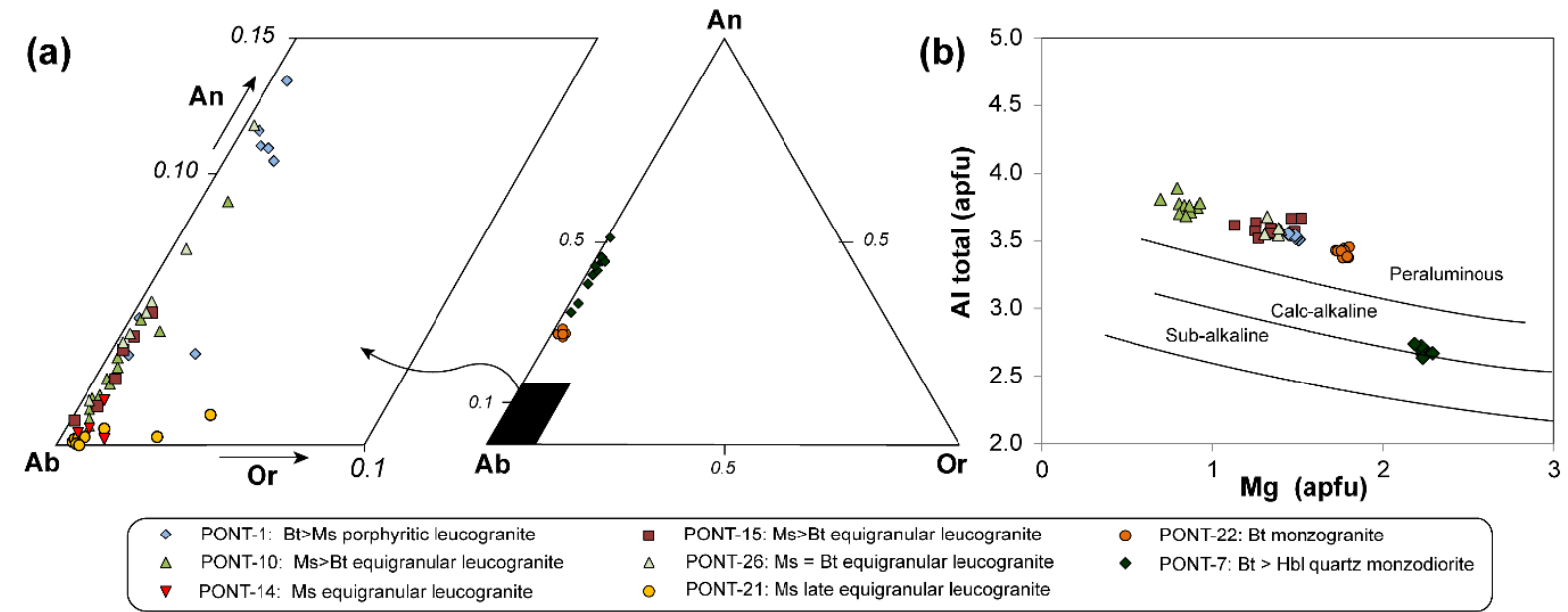

(c)
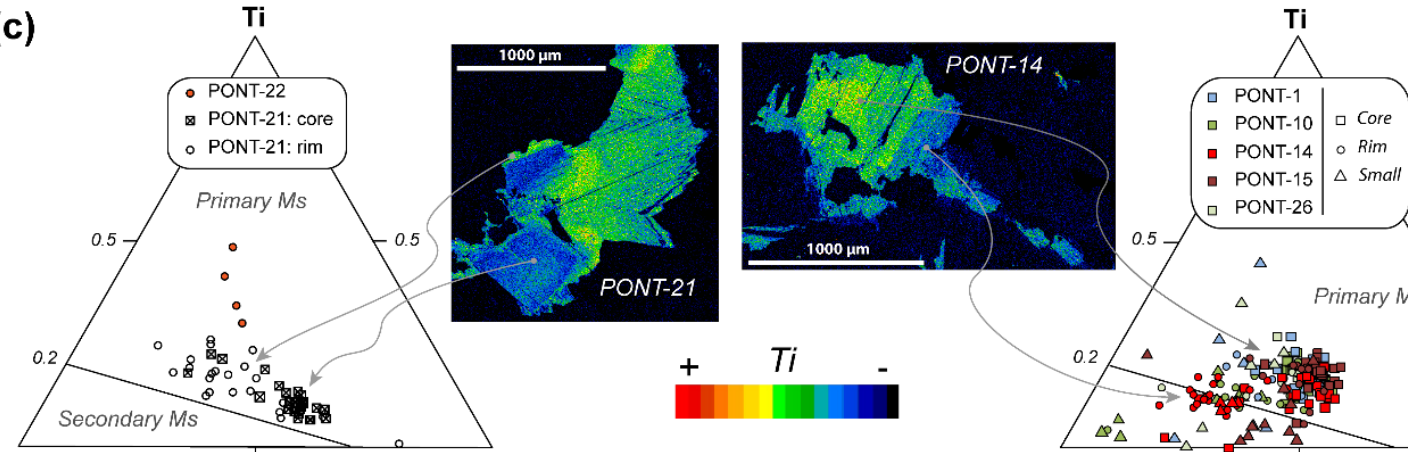

$\triangle \quad$ Primary Ms

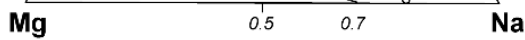

Mg Secondary Ms

Figure 5 

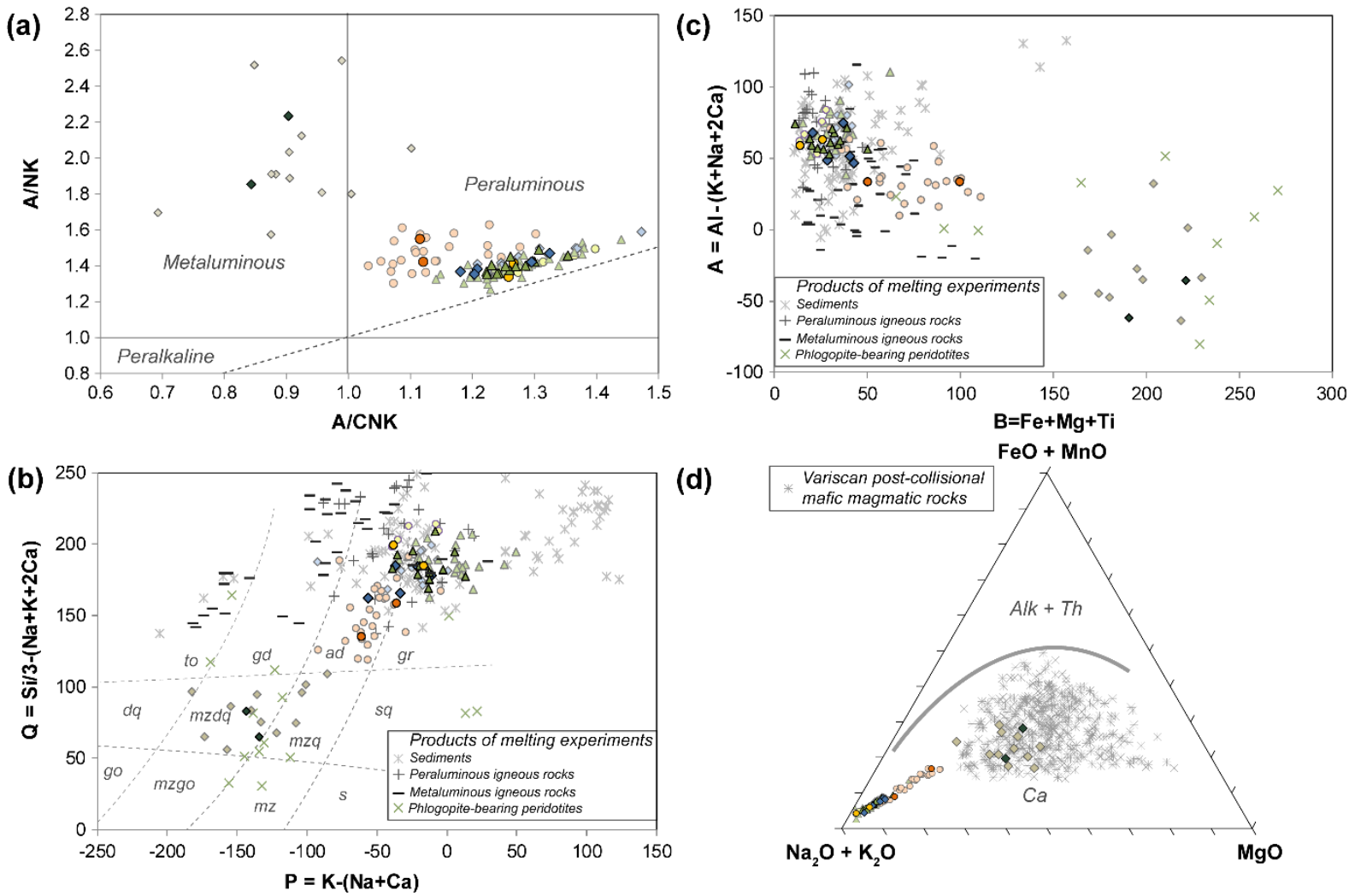

(d)

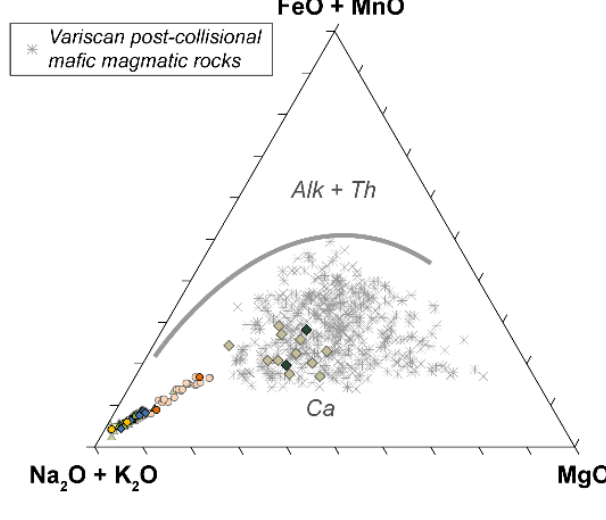

$\diamond \diamond \quad$ Porphyritic leucogranite $\circ \circ$ Late equigranular leucogranite

$\diamond \quad$ Quartz monzodiorite

$\Delta \Delta \quad$ Equigranular leucogranite $\circ \circ$ Monzogranite

Figure 6 


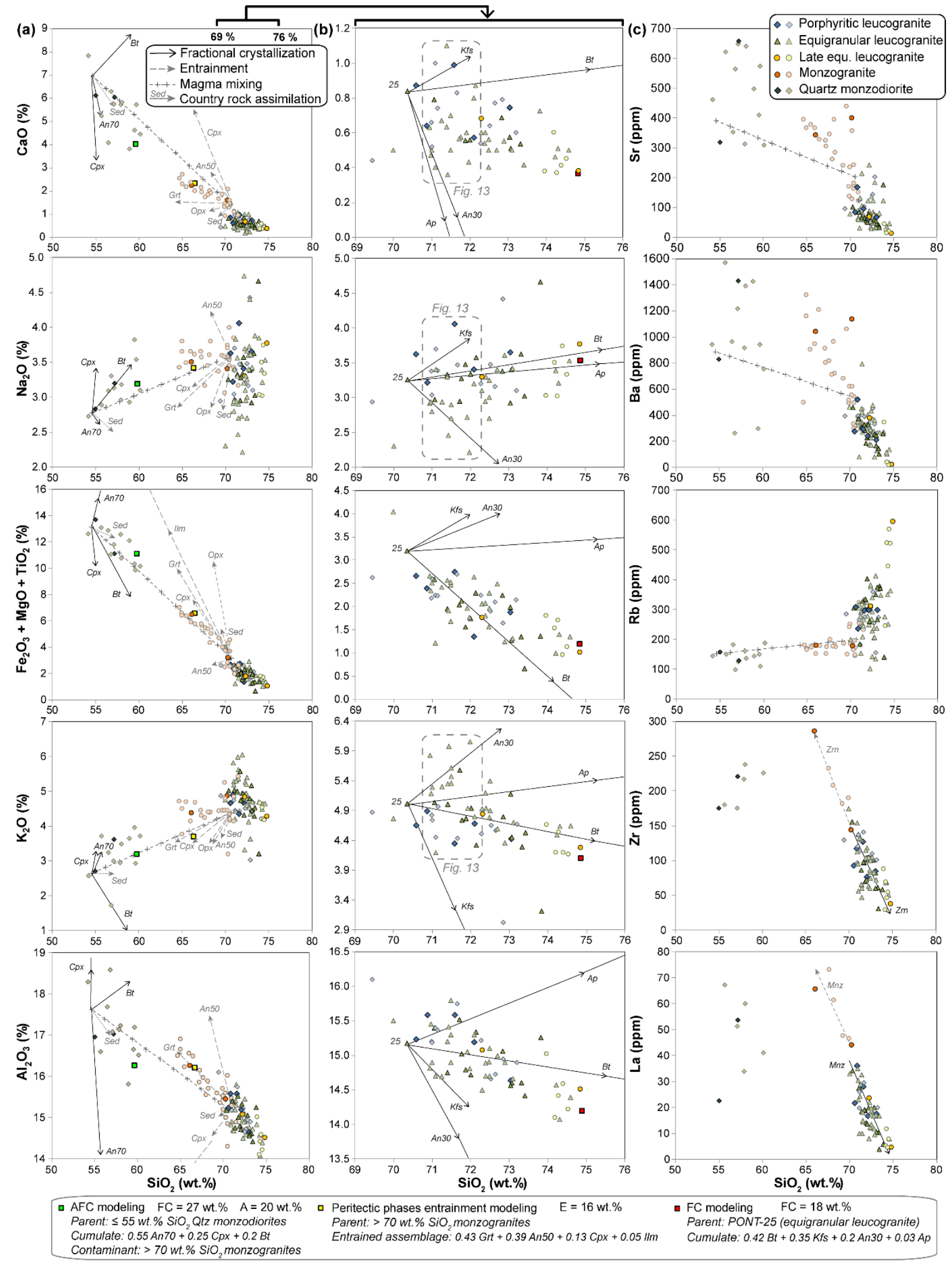

Figure 7 


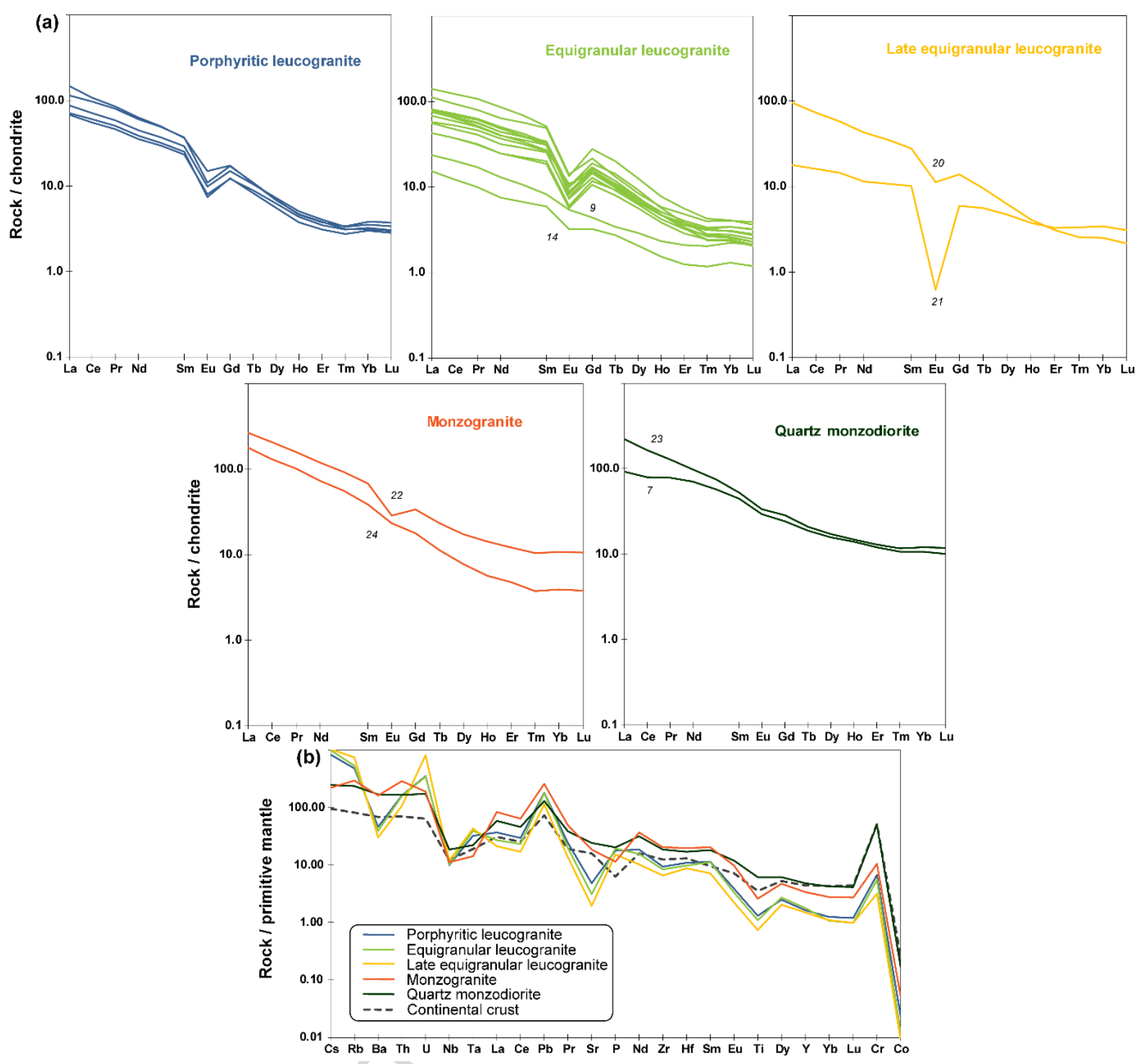

Figure 8 


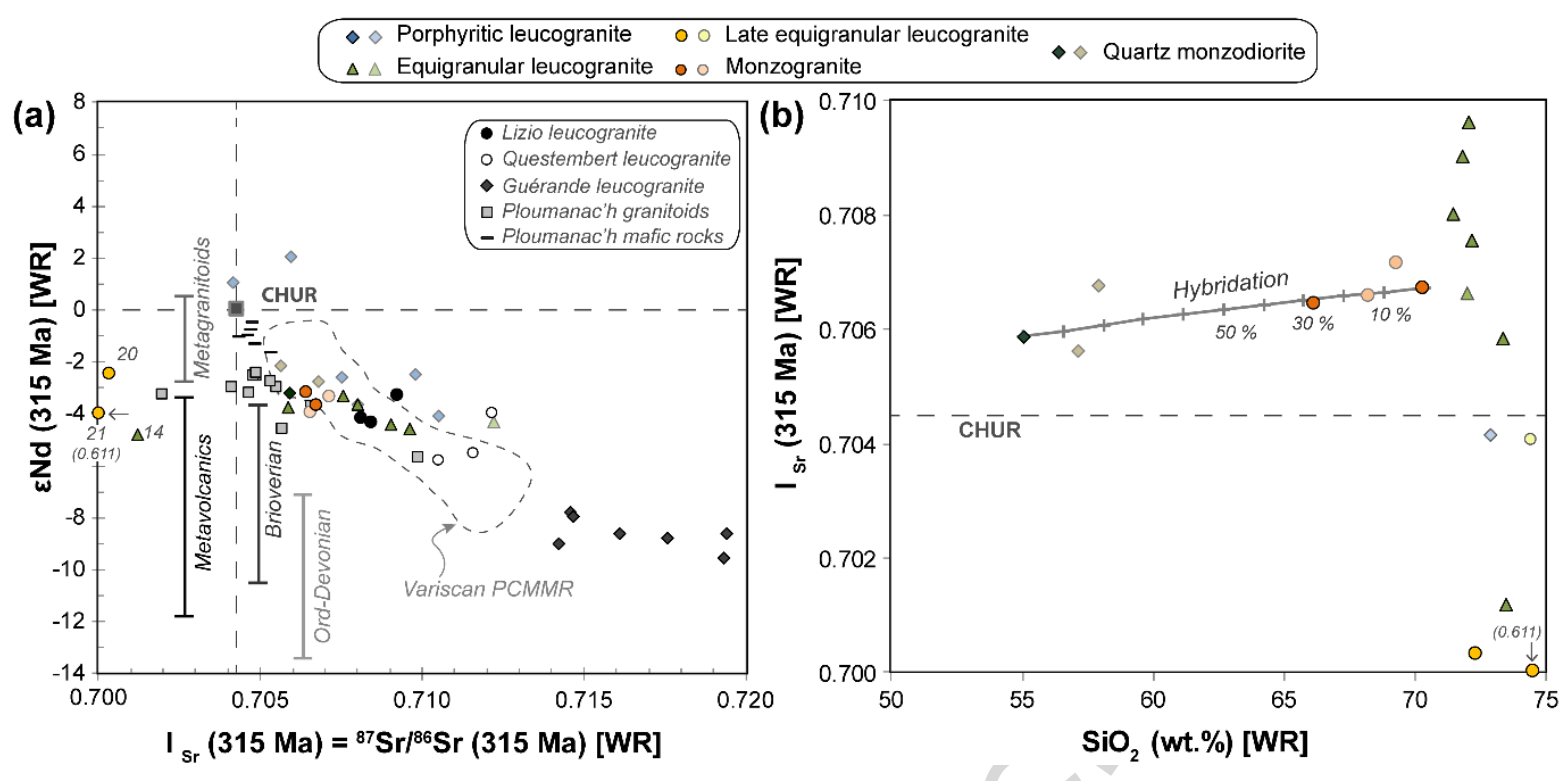

Figure 9 


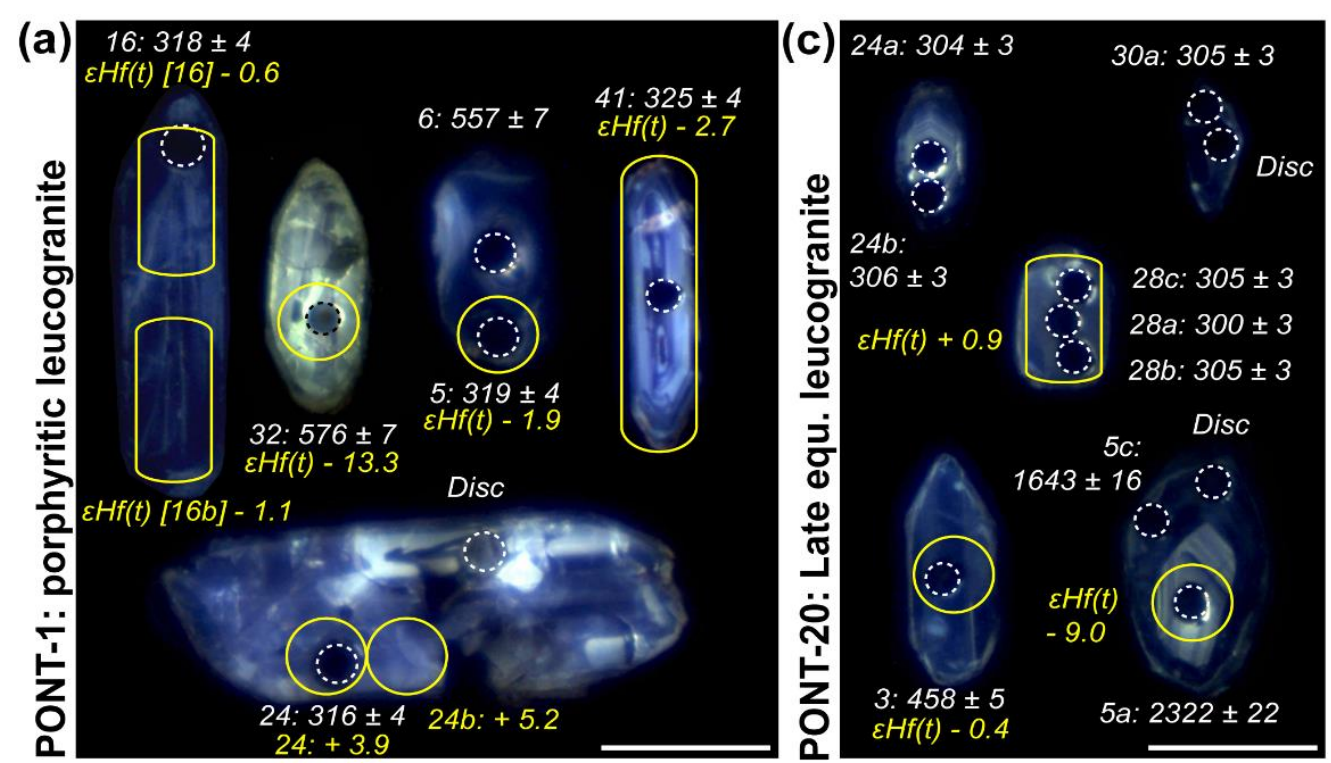
(b) $8 b$ :

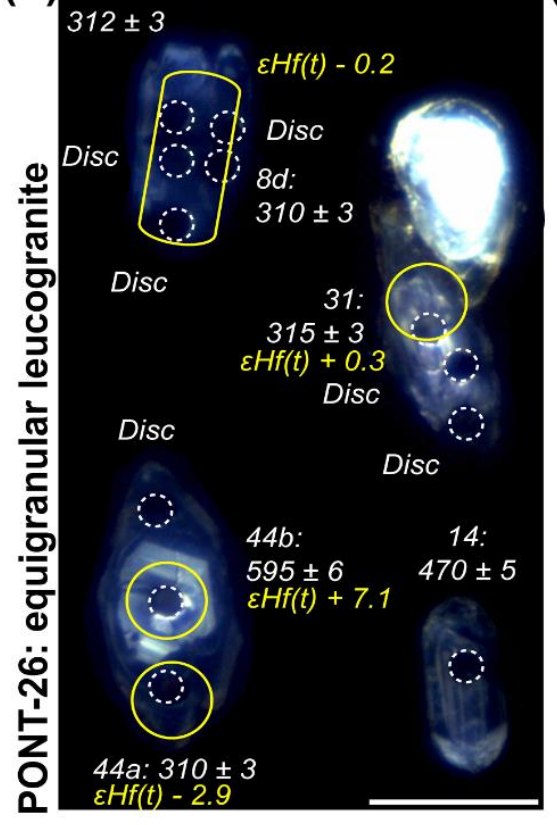

(d) $1: 314 \pm 4$

$\varepsilon H f(t)-0.4$

5a: $2322 \pm 22$
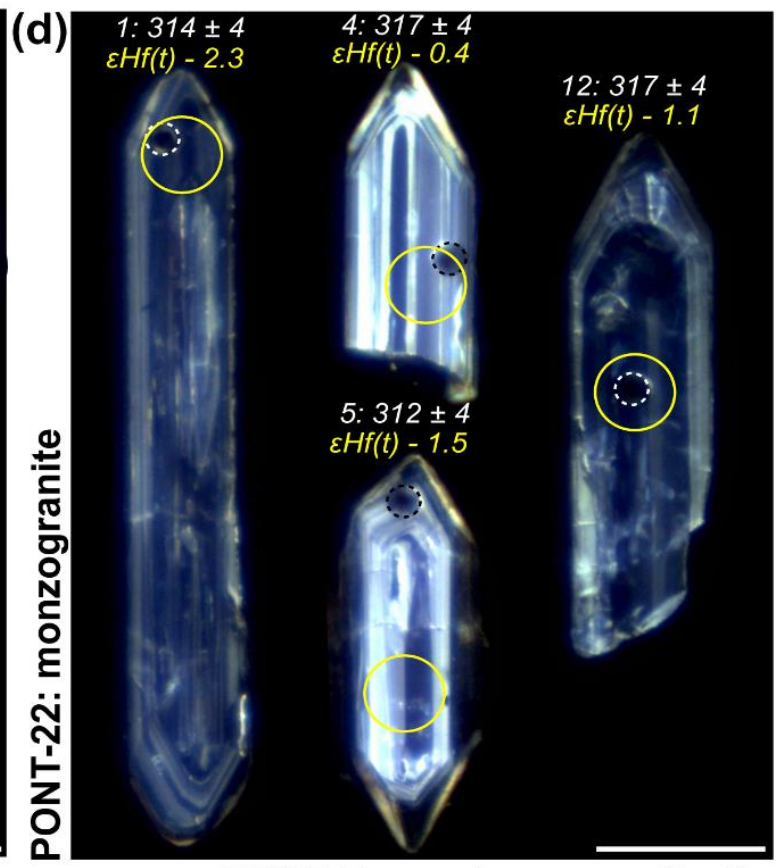

PONT-7: quartz monzodiorite

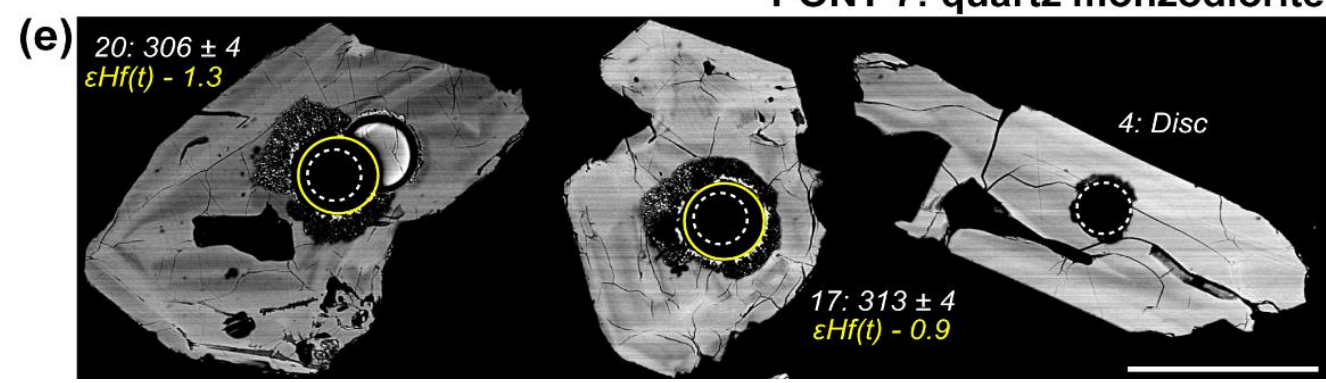

Figure 10 


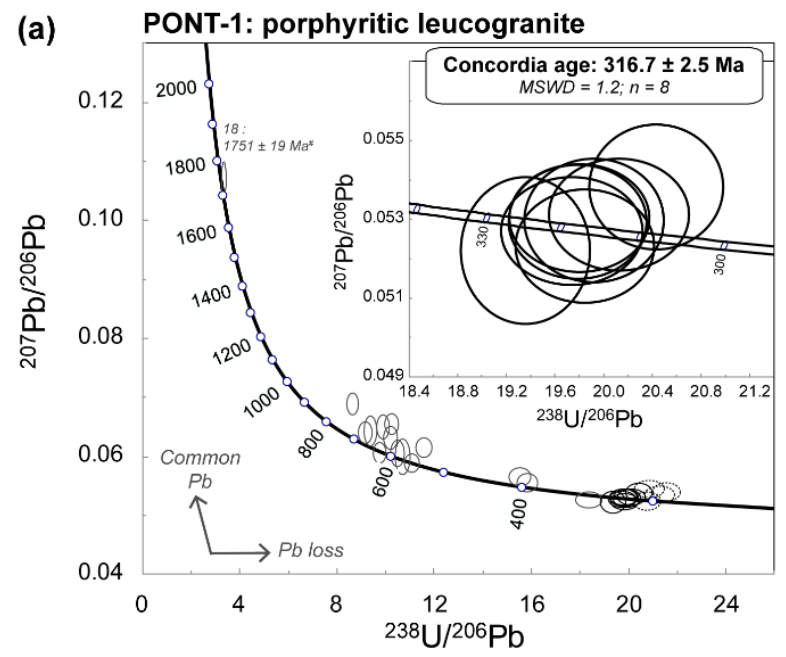

(c) PONT-20: late equigranular leucogranite

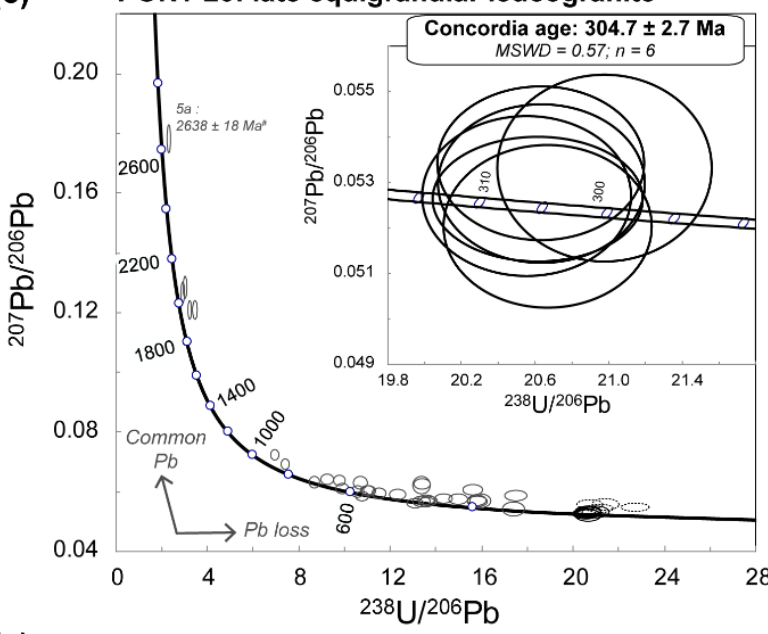

(e) PONT-22: monzogranite

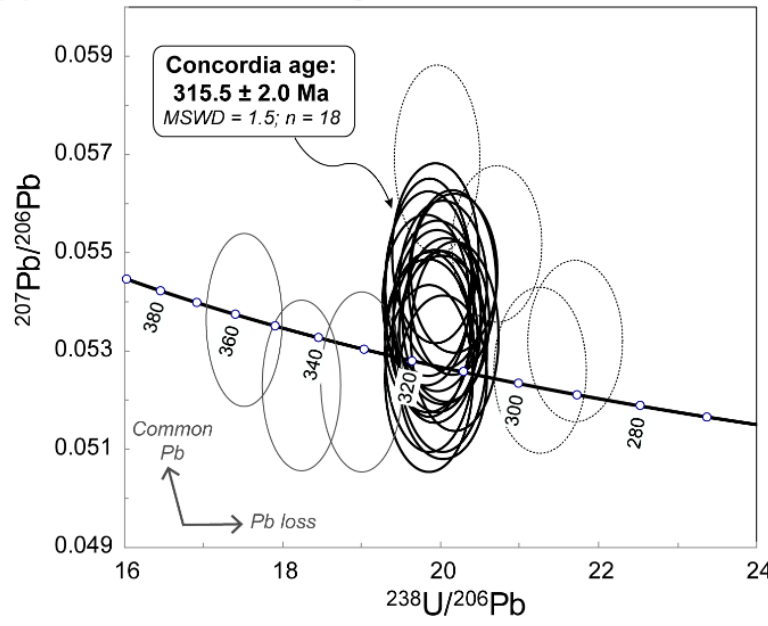

(b) 0.14 PONT-26: equigranular leucogranite

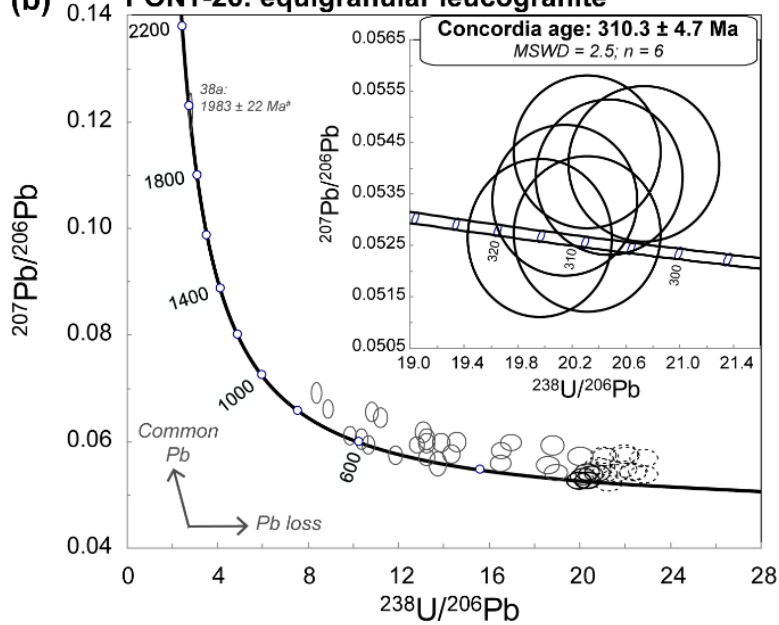

(d)

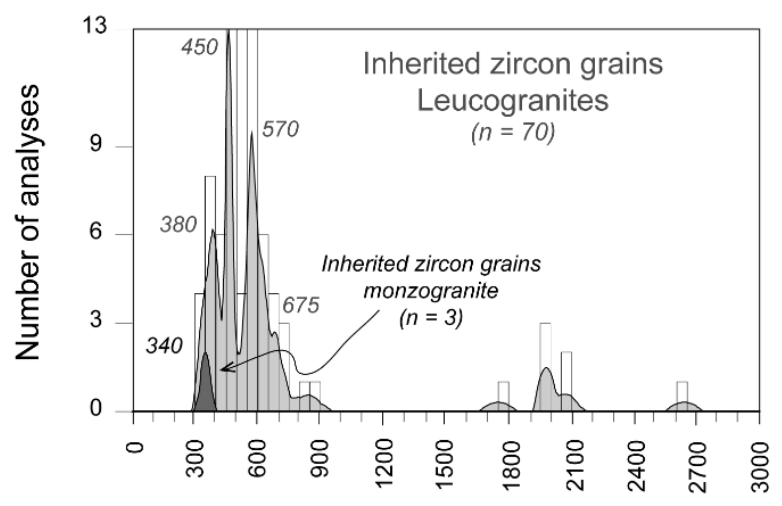

Age (Ma)

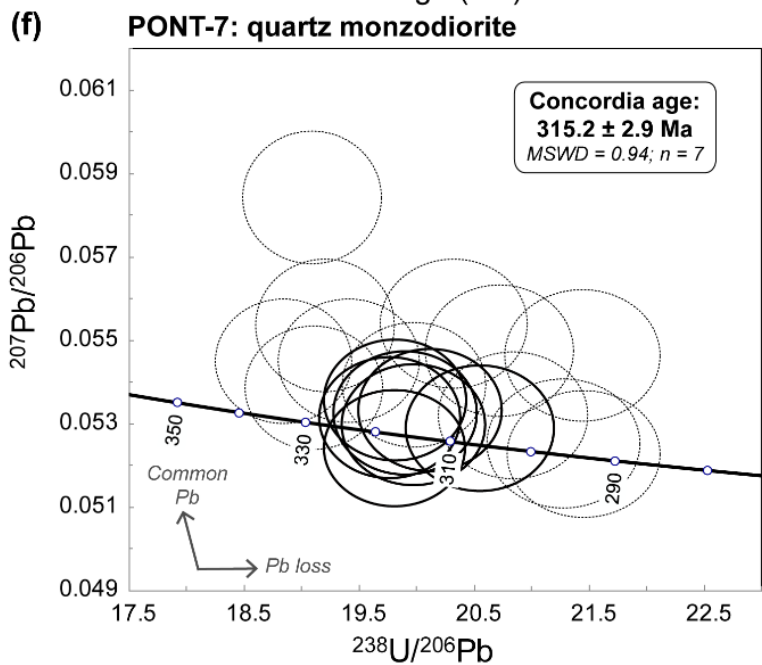

Figure 11 

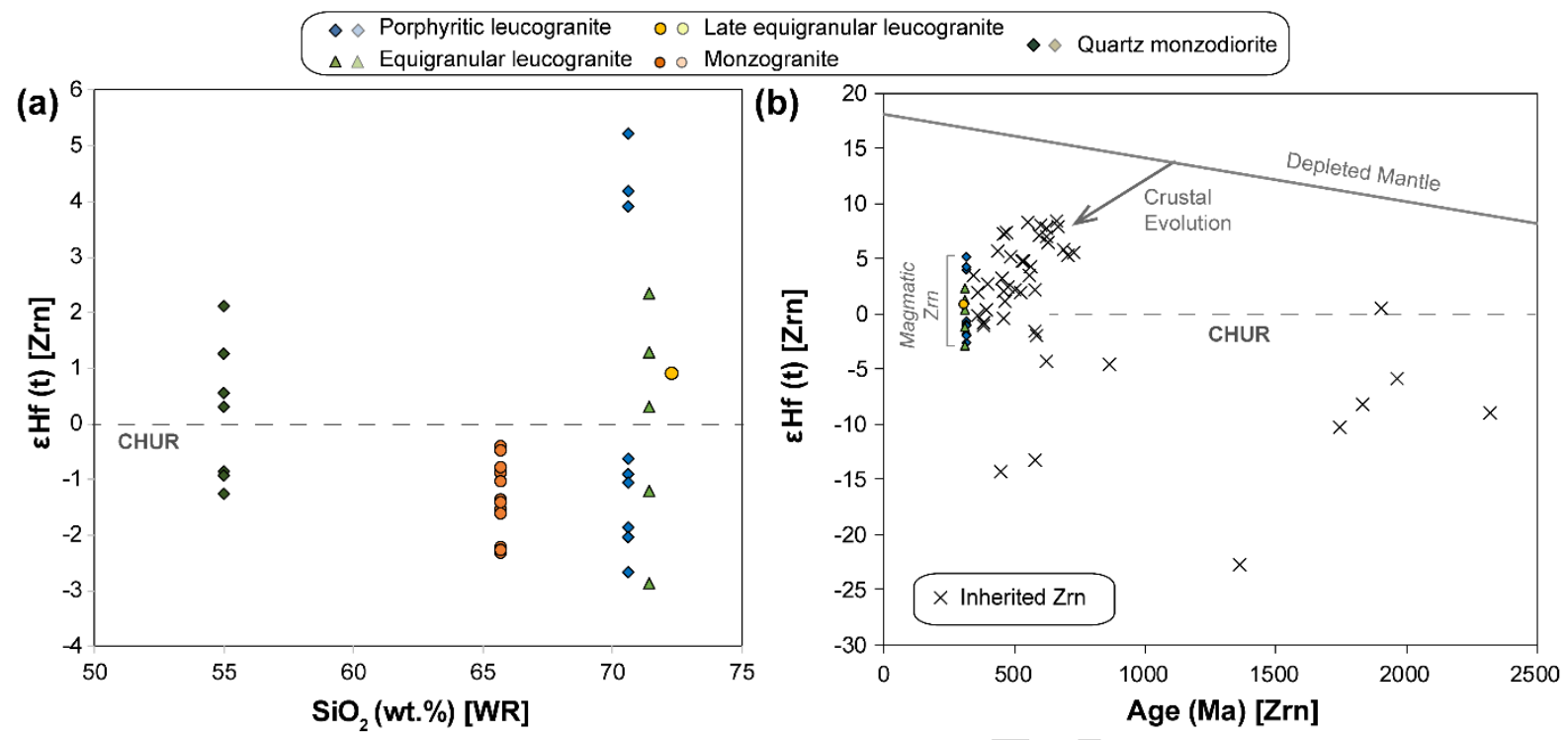

Figure 12 

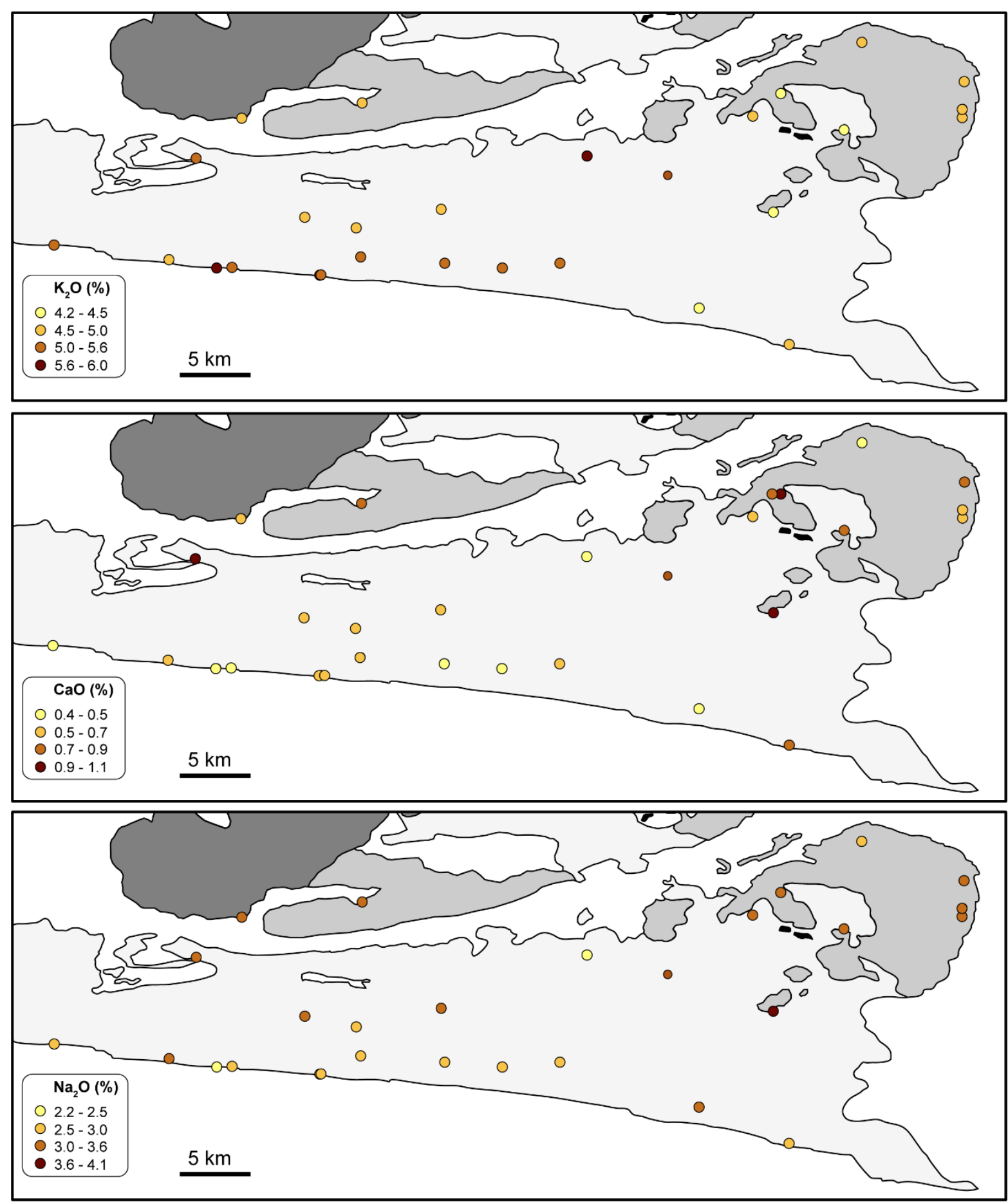

Porphyritic leucogranite $\square$ Equigranular leucogranite $\square$ Late equigranular leucogranite

Figure 13 


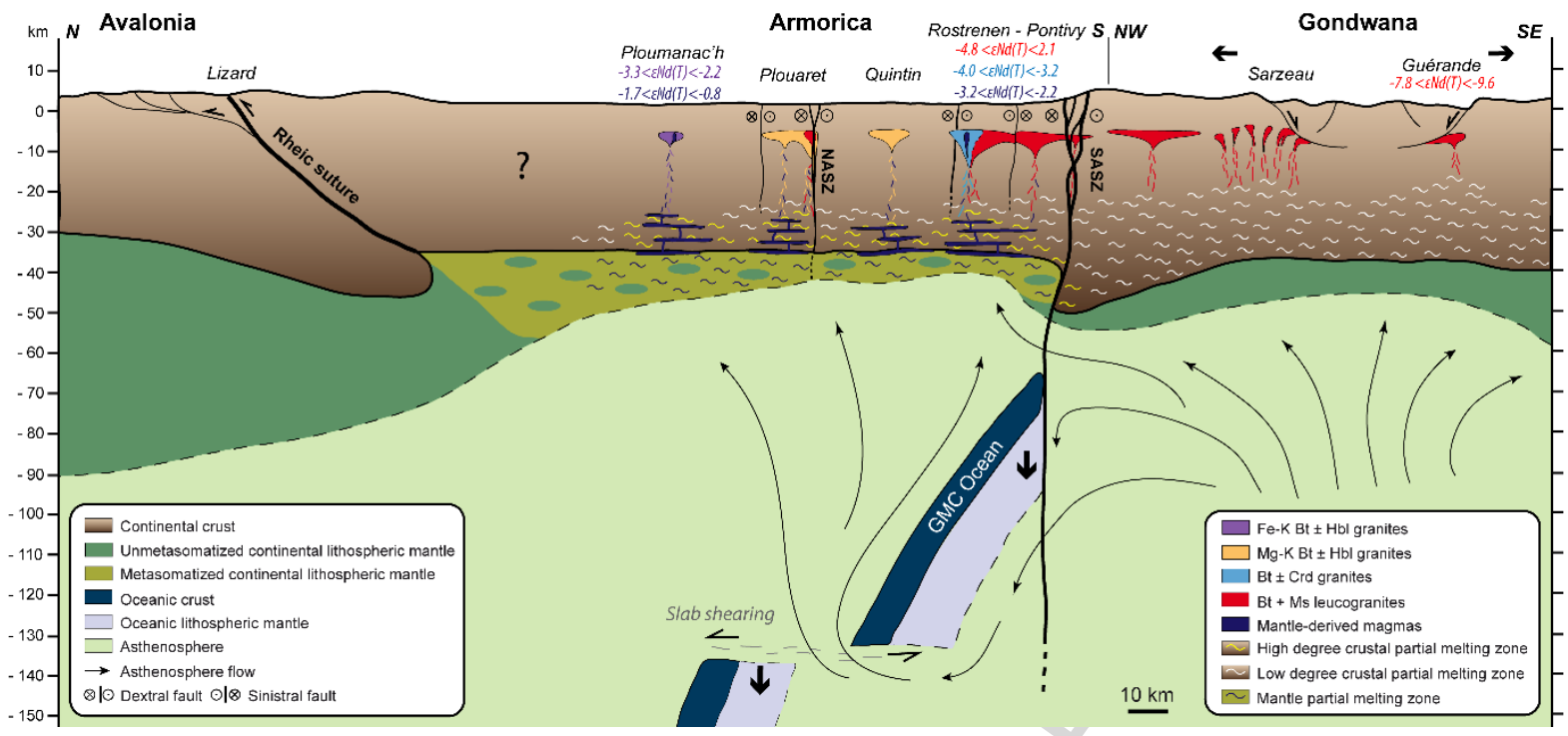

Figure 14 


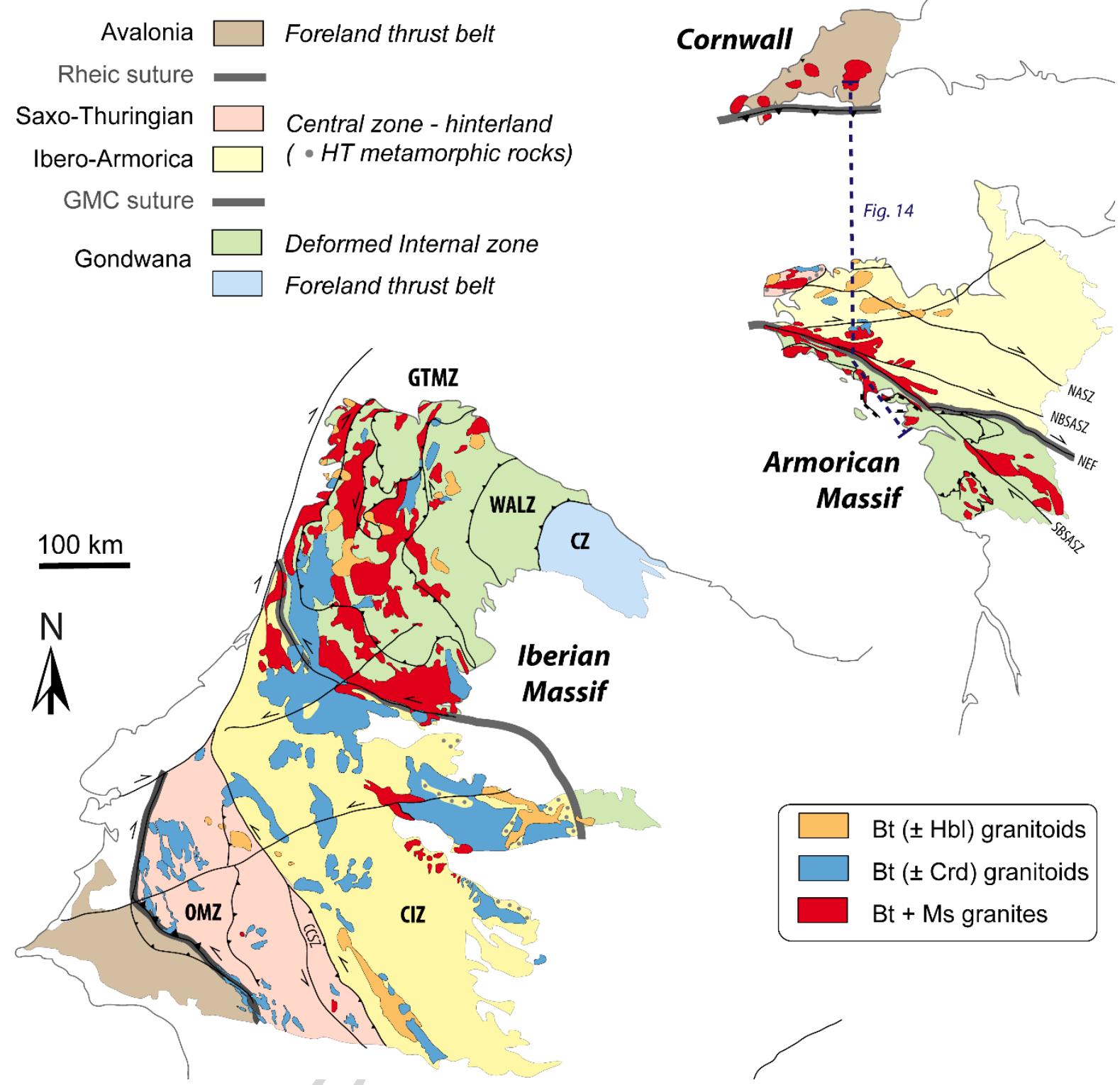

Figure 15 
Table 1

\begin{tabular}{|c|c|c|c|c|c|c|c|}
\hline Longitude $\left({ }^{\circ}\right.$ ) & Lattitude $\left({ }^{\circ}\right)$ & Sample & Facies & Mineralogy & Texture & Strain & Chloritization \\
\hline-3.000557 & 48.062879 & PONT-1 & $\begin{array}{l}\text { Porphyritic } \\
\text { leucogranite }\end{array}$ & $\mathrm{Bt}>\mathrm{Ms}$ & $\begin{array}{l}\text { Porphyritic }(1-2 \mathrm{~cm}) \text {, coarse grained }(2-5 \\
\mathrm{mm}), \text { magmatic foliation }\end{array}$ & & Chl+ \\
\hline-3.001773 & 48.045242 & PONT-2 & $\begin{array}{l}\text { Porphyritic } \\
\text { leucogranite }\end{array}$ & $\mathrm{Ms}>\mathrm{Bt}$ & $\begin{array}{c}\text { Porphyritic }(1-2 \mathrm{~cm}) \text {, coarse grained }(3-5 \\
\mathrm{mm})\end{array}$ & & Chl \\
\hline-3.117447 & 48.055276 & PONT-5 & $\begin{array}{l}\text { Porphyritic } \\
\text { leucogranite }\end{array}$ & $\mathrm{Bt}>\mathrm{Ms}$ & $\begin{array}{l}\text { Moderatley porphyritic }(0.5-2 \mathrm{~cm}) \text {, } \\
\text { medium to coarse grained }(1-4 \mathrm{~mm}) \text {, } \\
\text { magmatic foliation }\end{array}$ & + & $\mathrm{Chl}$ \\
\hline-3.117447 & 48.055276 & PONT-11 & $\begin{array}{l}\text { Porphyritic } \\
\text { leucogranite }\end{array}$ & $\mathrm{Bt}>\mathrm{Ms}$ & $\begin{array}{l}\text { Porphyritic }(1-2 \mathrm{~cm}), \text { medium to coarse } \\
\text { grained }(2-4 \mathrm{~mm})\end{array}$ & + & Chl- \\
\hline-3.461017 & 48.039550 & PONT-19 & $\begin{array}{l}\text { Porphyritic } \\
\text { leucogranite }\end{array}$ & $\mathrm{Bt}>\mathrm{Ms}$ & $\begin{array}{c}\text { Porphyritic }(1-2 \mathrm{~cm}) \text {, coarse grained }(3-5 \\
\mathrm{mm})\end{array}$ & & $\mathrm{Chl}+++$ \\
\hline-3.077133 & 48.032150 & PONT-3 & $\begin{array}{l}\text { Equigranular } \\
\text { leucogranite }\end{array}$ & $\mathrm{Bt}>\mathrm{Ms}$ & $\begin{array}{l}\text { Medium to fine grained }(0.5-2 \mathrm{~mm}) \text {, } \\
\text { slightly porphyritic }(1-2 \mathrm{~cm}), \text { magmatic } \\
\text { foliation }\end{array}$ & + & Chl- \\
\hline-3.135274 & 48.040860 & PONT-6 & $\begin{array}{l}\text { Equigranular } \\
\text { leucogranite }\end{array}$ & $\mathrm{Bt}>\mathrm{Ms}$ & $\begin{array}{c}\text { Fine to medium grained, magmatic } \\
\text { foliation }\end{array}$ & + & $\mathrm{Chl}++$ \\
\hline-3.052191 & 47.955898 & PONT-9 & $\begin{array}{l}\text { Equigranular } \\
\text { leucogranite }\end{array}$ & $\begin{array}{l}\text { Ms }>\mathrm{Bt}- \\
\text { (Turm) }\end{array}$ & $\begin{array}{c}\text { Medium grained (1-3 } \mathrm{mm}) \text {, solid state } \\
\text { deformation }\end{array}$ & ++ & Chl \\
\hline-3.300926 & 47.935201 & PON-10 & $\begin{array}{l}\text { Equigranular } \\
\text { leucogranite }\end{array}$ & $\mathrm{Ms}>\mathrm{Bt}$ & $\begin{array}{l}\text { Coarse grained }(2-5 \mathrm{~mm}) \text {, slightly } \\
\text { porphyritic, magmatic foliation }\end{array}$ & ++ & Chl \\
\hline-3.390235 & 47.984733 & PONT-12 & $\begin{array}{l}\text { Equigranular } \\
\text { leucogranite }\end{array}$ & $\mathrm{Ms}>\mathrm{Bt}$ & $\begin{array}{l}\text { Coarse grained }(2-7 \mathrm{~mm}) \text {, slightly } \\
\text { porphyritic }(1 \mathrm{~cm})\end{array}$ & & Chl \\
\hline-3.420917 & 47.976350 & PONT-13 & $\begin{array}{l}\text { Equigranular } \\
\text { leucogranite }\end{array}$ & $\mathrm{Ms}>\mathrm{Bt}$ & $\begin{array}{l}\text { Medium to coarse grained }(1-7 \mathrm{~mm}) \\
\text { slightly porphyritic }(1 \mathrm{~cm})\end{array}$ & & $\mathrm{Chl+}$ \\
\hline-3.428067 & 47.980217 & PONT-14 & $\begin{array}{l}\text { Equigranular } \\
\text { leucogranite }\end{array}$ & Ms & Medium to coarse grained (2-6 mm) & & \\
\hline-3.507400 & 47.949383 & PONT-15 & $\begin{array}{l}\text { Equigranular } \\
\text { leucogranite }\end{array}$ & $\mathrm{Ms}>\mathrm{Bt}$ & $\begin{array}{c}\text { Fine grained }(0.5-3 \mathrm{~mm}), \text { magmatic } \\
\text { foliation }\end{array}$ & + & Chl- \\
\hline-3.060517 & 47.903217 & PONT-17 & $\begin{array}{l}\text { Equigranular } \\
\text { leucogranite }\end{array}$ & $\mathrm{Bt}=\mathrm{Ms}$ & $\begin{array}{c}\text { Coarse grained }(2-8 \mathrm{~mm}) \text {, slightly } \\
\text { porphyritic }(2 \mathrm{~cm}) \text {, magmatic foliation }\end{array}$ & ++ & \\
\hline-3.112083 & 47.895200 & PONT-18 & $\begin{array}{l}\text { Equigranular } \\
\text { leucogranite }\end{array}$ & $\mathrm{Bt}>\mathrm{Ms}$ & $\begin{array}{l}\text { Fined grained }(\leq 2 \mathrm{~mm}) \text {, slightly } \\
\text { porphyritic, solid state deformation }\end{array}$ & +++ & Chl+++ \\
\hline-3.374485 & 48.149737 & PONT-25 & $\begin{array}{l}\text { Equigranular } \\
\text { leucogranite }\end{array}$ & $\mathrm{Ms} \gg \mathrm{Bt}$ & $\begin{array}{l}\text { Medium to fine grained }(2-3 \mathrm{~mm}) \text {, slightly } \\
\text { porphyritic }(1-2 \mathrm{~cm})\end{array}$ & & Chl- \\
\hline-3.333955 & 47.981447 & PONT-26 & $\begin{array}{l}\text { Equigranular } \\
\text { leucogranite }\end{array}$ & $\mathrm{Ms}=\mathrm{Bt}$ & $\begin{array}{l}\text { Medium grained }(1-5 \mathrm{~mm}) \text {, slightly } \\
\text { porphyritic }(1 \mathrm{~cm}) \text {, magmatic foliation }\end{array}$ & + & $\mathrm{Chl+}$ \\
\hline-3.258245 & 47.947043 & PONT-27 & $\begin{array}{l}\text { Equigranular } \\
\text { leucogranite }\end{array}$ & $\mathrm{Ms}>\mathrm{Bt}$ & $\begin{array}{l}\text { Medium to coarse grained }(1-3 \mathrm{~mm}) \\
\text { magmatic foliation }\end{array}$ & + & Chl- \\
\hline-3.391240 & 47.990710 & PONT-28 & $\begin{array}{l}\text { Equigranular } \\
\text { leucogranite }\end{array}$ & $\mathrm{Bt}=\mathrm{Ms}$ & $\begin{array}{c}\text { Coarse grained }(0.5-1 \mathrm{~cm}) \text {, slightly } \\
\text { porphyritic }(1-2 \mathrm{~cm}), \text { magmatic foliation }\end{array}$ & + & Chl- \\
\hline-3.472679 & 48.071121 & PONT-20 & $\begin{array}{l}\text { Late equ. } \\
\text { leucogranite }\end{array}$ & $\mathrm{Bt}>\mathrm{Ms}$ & $\begin{array}{l}\text { Fine grained }(1-4 \mathrm{~mm}) \text {, slightly porphyritic } \\
\qquad(1-2 \mathrm{~cm})\end{array}$ & & Chl - - \\
\hline-3.390833 & 48.131267 & PONT-21 & $\begin{array}{l}\text { Late equ. } \\
\text { leucogranite }\end{array}$ & Fs - Ms & Medium to coarse grained (2-4 mm) & & \\
\hline-3.338700 & 48.220583 & PONT-22 & Monzogranite & $\mathrm{Bt}-(\mathrm{Ms})$ & $\begin{array}{l}\text { Highly porphyritic }(1-4 \mathrm{~cm}), \text { medium } \\
\text { grained }(2-4 \mathrm{~mm})\end{array}$ & & Chl - - \\
\hline-3.257395 & 48.196251 & PONT-24 & Monzogranite & $\begin{array}{l}\mathrm{Bt}-(\mathrm{Ms}- \\
\quad \mathrm{Cd} ?)\end{array}$ & $\begin{array}{l}\text { Porphyritic }(1-2 \mathrm{~cm}), \text { medium to fine } \\
\text { grained }(1-3 \mathrm{~mm})\end{array}$ & & Chl- \\
\hline-3.116167 & 48.031867 & PONT-7 & $\begin{array}{l}\text { Quartz } \\
\text { monzodiorite }\end{array}$ & $\mathrm{Bt}>\mathrm{Act}$ & Fine grained $(0.5-1 \mathrm{~mm})$ & & Chl- \\
\hline-3.211867 & 48.224141 & PONT-23 & $\begin{array}{c}\text { Quartz } \\
\text { monzodiorite }\end{array}$ & $\begin{array}{c}\mathrm{Bt}>\mathrm{Act}> \\
\mathrm{CPx}\end{array}$ & Medium grained (2-4 mm) & & \\
\hline-3.740952 & 47.811525 & QIMP-1 & $\begin{array}{c}\text { Moelan } \\
\text { Metagranitoid } \\
\text { (tonalite) }\end{array}$ & $\mathrm{Ms}>\mathrm{Bt}$ & Fine grained $(\leq 1 \mathrm{~mm})$, mylonitic & ++++ & Chl- \\
\hline-2.63975 & 48.274317 & PLG-1 & $\begin{array}{l}\text { Plouguenast } \\
\text { Metagranitoid } \\
\text { (granite) }\end{array}$ & $\mathrm{Bt}>\mathrm{Ms}$ & $\begin{array}{l}\text { Medium Grained (2-5 mm), ductile } \\
\text { deformation }\end{array}$ & +++ & \\
\hline-2.545533 & 48.270633 & PLG-2 & $\begin{array}{l}\text { Plouguenast } \\
\text { Metagranitoid } \\
\text { (tonalite) }\end{array}$ & $\mathrm{Bt}>\mathrm{Ms}$ & $\begin{array}{l}\text { Fine grained }(\leq 1 \mathrm{~mm}) \text {, slightly porphyritic } \\
\quad(2-5 \mathrm{~mm}) \text {, ductile deformation }\end{array}$ & ++++ & \\
\hline-2.55685 & 48.255217 & PLG-3 & $\begin{array}{l}\text { Plouguenast } \\
\text { Metagranitoid } \\
\text { (granite) }\end{array}$ & $\mathrm{Ms}>\mathrm{Bt}$ & $\begin{array}{l}\text { Medium grained ( } 1-4 \mathrm{~mm}) \text {, semi-brittle } \\
\text { deformation }\end{array}$ & ++ & \\
\hline-2.615186 & 48.19458 & PLG-4 & $\begin{array}{l}\text { Plouguenast } \\
\text { Metagranitoid } \\
\text { (tonalite) }\end{array}$ & $\begin{array}{l}\mathrm{Ms} \gg \mathrm{Chl} \\
\text { (Bt) }\end{array}$ & $\begin{array}{l}\text { Fine grained }(\leq 1 \mathrm{~mm}) \text {, semi-brittle } \\
\text { deformation }\end{array}$ & ++ & $\mathrm{Chl++}$ \\
\hline
\end{tabular}

Late equ. Leucogranite: late equigranular leucogranite 
Table 2

\begin{tabular}{|c|c|c|c|c|c|c|c|c|c|c|c|c|c|c|}
\hline Sample & & $\begin{array}{c}\text { PONT } \\
-1 \\
\end{array}$ & $\begin{array}{c}\text { PONT } \\
-2 \\
\end{array}$ & $\begin{array}{c}\text { PONT } \\
-5 \\
\end{array}$ & $\begin{array}{c}\text { PONT- } \\
11\end{array}$ & $\begin{array}{c}\text { PONT- } \\
19 \\
\end{array}$ & $\begin{array}{c}\text { PONT } \\
-3 \\
\end{array}$ & $\begin{array}{c}\text { PONT } \\
-6 \\
\end{array}$ & $\begin{array}{c}\text { PONT } \\
-9 \\
\end{array}$ & $\begin{array}{c}\text { PONT } \\
-10 \\
\end{array}$ & $\begin{array}{c}\text { PONT } \\
-12 \\
\end{array}$ & $\begin{array}{c}\text { PONT } \\
-13 \\
\end{array}$ & $\begin{array}{c}\text { PONT- } \\
14\end{array}$ & $\begin{array}{c}\text { PONT- } \\
15\end{array}$ \\
\hline Facies & & \multicolumn{5}{|c|}{ Porphyritic leucogranite } & \multicolumn{8}{|c|}{ Equigranular leucogranite } \\
\hline $\mathrm{SiO}_{2}$ & Wt.\% & 70.59 & 72.10 & 73.05 & 71.59 & 70.88 & 72.15 & 71.77 & 73.83 & 73.33 & 73.07 & 71.88 & 73.42 & 72.01 \\
\hline $\mathbf{A l}_{2} \mathbf{O}_{3}$ & Wt. \% & 15.23 & 15.19 & 14.64 & 15.58 & 15.58 & 15.34 & 15.02 & 15.26 & 14.61 & 14.60 & 14.79 & 14.42 & 14.72 \\
\hline $\mathrm{Fe}_{2} \mathrm{O}_{3}$ & Wt.\% & 1.82 & 0.86 & 1.28 & 1.80 & 1.58 & 1.53 & 1.46 & 0.94 & 0.98 & 0.90 & 1.10 & 0.38 & 1.23 \\
\hline $\mathrm{MnO}$ & Wt.\% & 0.03 & 0.01 & 0.03 & 0.03 & 0.02 & 0.02 & 0.02 & 0.04 & 0.02 & 0.01 & 0.02 & 0.01 & 0.01 \\
\hline MgO & Wt.\% & 0.57 & 0.29 & 0.39 & 0.64 & 0.51 & 0.50 & 0.42 & 0.32 & 0.22 & 0.22 & 0.28 & 0.19 & 0.33 \\
\hline $\mathrm{CaO}$ & Wt.\% & 0.87 & 0.57 & 0.74 & 0.99 & 0.64 & 0.87 & 0.58 & 0.73 & 0.53 & 0.51 & 0.56 & 0.42 & 0.56 \\
\hline $\mathrm{Na}_{2} \mathrm{O}$ & Wt.\% & 3.63 & 3.41 & 3.65 & 4.06 & 3.22 & 3.57 & 3.28 & 4.66 & 3.62 & 3.40 & 3.48 & 3.02 & 3.34 \\
\hline $\mathbf{K}_{2} \mathbf{O}$ & Wt.\% & 4.66 & 4.69 & 4.43 & 4.35 & 4.89 & 4.33 & 4.74 & 3.22 & 4.29 & 4.45 & 4.77 & 4.53 & 4.95 \\
\hline $\mathrm{TiO}_{2}$ & Wt.\% & 0.28 & 0.21 & 0.21 & 0.31 & 0.31 & 0.26 & 0.24 & 0.11 & 0.15 & 0.15 & 0.18 & 0.09 & 0.19 \\
\hline $\mathbf{P}_{2} \mathrm{O}_{5}$ & Wt.\% & 0.37 & 0.36 & 0.38 & 0.42 & 0.30 & 0.35 & 0.34 & 0.26 & 0.45 & 0.44 & 0.47 & 0.41 & 0.42 \\
\hline LOI & Wt.\% & 1.16 & 1.54 & 0.73 & 1.01 & 1.89 & 1.77 & 1.42 & 1.13 & 1.33 & 1.29 & 1.34 & 1.82 & 1.34 \\
\hline Total & Wt.\% & 99.20 & 99.21 & 99.52 & 100.77 & 99.80 & 100.69 & 99.29 & 100.49 & 99.54 & 99.05 & 98.85 & 98.71 & 99.09 \\
\hline $\mathbf{L i}$ & ppm & 257 & 202 & 205 & 224 & 66 & 174 & 188 & 225 & 310 & 272 & 251 & 135 & 184 \\
\hline Cs & ppm & 29.5 & 16.9 & 19.6 & 16.6 & 4.6 & 22.8 & 15.3 & 19.9 & 34.0 & 33.2 & 31.4 & 30.3 & 19.1 \\
\hline $\mathbf{R b}$ & ppm & 309 & 300 & 300 & 298 & 236 & 261 & 301 & 141 & 380 & 376 & 403 & 372 & 305 \\
\hline Sn & ppm & 14.1 & 11.1 & 10.9 & 10.1 & 5.8 & 12.2 & 12.6 & 11.6 & 24.1 & 26.8 & 24.1 & 22.0 & 15.3 \\
\hline $\mathbf{W}$ & ppm & 1.30 & 1.53 & 1.39 & 1.39 & 1.18 & 0.49 & 1.76 & 0.33 & 3.56 & 3.58 & 2.75 & 2.86 & 1.58 \\
\hline $\mathbf{B a}$ & ppm & 277 & 239 & 210 & 293 & 518 & 327 & 283 & 260 & 146 & 167 & 184 & 101 & 229 \\
\hline $\mathbf{S r}$ & ppm & 83.9 & 62.3 & 67.7 & 96.4 & 167.6 & 78.8 & 63.4 & 176.7 & 41.5 & 46.1 & 55.4 & 32.9 & 49.4 \\
\hline $\mathbf{B e}$ & ppm & 12.1 & 5.8 & 7.1 & 7.3 & 5.2 & 7.5 & 6.4 & 18.2 & 6.1 & 7.5 & 14.6 & 19.3 & 7.3 \\
\hline $\mathbf{U}$ & ppm & 7.76 & 4.30 & 9.75 & 8.15 & 5.89 & 5.22 & 6.75 & 3.04 & 5.60 & 8.88 & 7.36 & 4.02 & 5.08 \\
\hline Th & ppm & 12.08 & 9.29 & 10.87 & 17.79 & 15.07 & 9.59 & 17.34 & 1.34 & 6.57 & 6.26 & 13.48 & 2.63 & 8.37 \\
\hline Nb & ppm & 6.74 & 6.39 & 5.72 & 8.41 & 5.54 & 5.50 & 5.69 & 4.88 & 9.27 & 9.21 & 7.52 & 6.34 & 6.54 \\
\hline Ta & ppm & 1.27 & 1.41 & 1.02 & 1.47 & 0.78 & 1.19 & 1.05 & 1.80 & 2.35 & 2.38 & 2.44 & 2.17 & 1.41 \\
\hline $\mathrm{Zr}$ & ppm & 92.6 & 76.5 & 84.3 & 127.3 & 117.2 & 101.5 & 96.8 & 58.2 & 60.6 & 59.7 & 69.9 & 30.7 & 72.2 \\
\hline Hf & ppm & 2.96 & 2.48 & 2.67 & 3.92 & 3.51 & 3.17 & 2.99 & 2.00 & 2.07 & 2.04 & 2.21 & 1.21 & 2.37 \\
\hline $\mathbf{B i}$ & ppm & 1.05 & 0.36 & 1.63 & 1.01 & 1.02 & 0.73 & 0.85 & 1.45 & 1.45 & 1.53 & 1.68 & 1.36 & 0.83 \\
\hline Cd & ppm & 0.13 & bld & 0.15 & 0.21 & 0.15 & bld & 0.12 & bld & 0.14 & bld & 0.13 & bld & 0.14 \\
\hline Co & ppm & 3.85 & 1.16 & 1.56 & 1.93 & 3.88 & 1.80 & 1.68 & 1.05 & 0.57 & 0.67 & 0.55 & 0.73 & 0.88 \\
\hline $\mathrm{Cr}$ & ppm & 27.95 & 11.62 & 20.04 & 18.76 & 10.53 & 15.29 & 14.54 & 9.273 & 10.15 & 11.16 & 10.7 & 8.07 & 14.57 \\
\hline $\mathrm{Cu}$ & ppm & bld & bld & bld & & bld & bld & bld & bld & bld & bld & bld & bld & bld \\
\hline Ga & ppm & 24.4 & 24.0 & 24.4 & 26.1 & 25.3 & 23.9 & 23.4 & 20.0 & 24.0 & 25.0 & 24.8 & 23.5 & 22.7 \\
\hline $\mathbf{G e}$ & ppm & 1.76 & 1.86 & 1.70 & 1.64 & 1.35 & 1.64 & 1.71 & 1.81 & 1.97 & 1.95 & 1.98 & 2.01 & 1.71 \\
\hline In & ppm & bld & bld & bld & bld & bld & bld & bld & bld & 0.128 & 0.138 & 0.097 & 0.108 & 0.082 \\
\hline Mo & ppm & bld & bld & bld & bld & bld & bld & bld & bld & bld & bld & bld & bld & bld \\
\hline $\mathbf{N i}$ & ppm & bld & bld & bld & bld & bld & bld & bld & bld & bld & bld & bld & bld & bld \\
\hline $\mathbf{P b}$ & ppm & 27.5 & 25.7 & 23.5 & 25.4 & 34.2 & 26.3 & 26.7 & 19.8 & 21.6 & 24.8 & 23.3 & 19.8 & 28.1 \\
\hline Sc & ppm & 3.76 & 2.93 & 2.93 & 3.84 & 3.44 & 3.34 & 3.33 & 2.03 & 3.15 & 3.74 & 2.4 & 1.8 & 2.2 \\
\hline Sb & ppm & bld & 0.37 & bld & bld & bld & bld & bld & bld & bld & bld & bld & bld & bld \\
\hline $\mathbf{V}$ & ppm & 14.4 & 9.5 & 8.9 & 18.4 & 16.4 & 15.8 & 13.8 & 7.3 & 5.9 & 5.7 & 6.0 & 1.7 & 6.6 \\
\hline $\mathbf{Y}$ & ppm & 7.86 & 6.78 & 6.03 & 7.25 & 7.14 & 7.26 & 7.20 & 3.76 & 6.28 & 7.84 & 7.10 & 2.53 & 7.69 \\
\hline $\mathrm{Zn}$ & ppm & 86.94 & 39.97 & 83.15 & 100.6 & 62.86 & 71.51 & 78.21 & 43.32 & 75.61 & 64.34 & 58.67 & 36.8 & 83 \\
\hline As & ppm & bld & 1.591 & 2.22 & bld & 1.823 & bld & bld & 1.689 & 2.583 & 8.871 & 4.251 & bld & 3.969 \\
\hline La & ppm & 21.62 & 16.72 & 17.52 & 27.94 & 36.00 & 19.81 & 18.84 & 5.79 & 10.47 & 10.49 & 14.12 & 3.77 & 13.68 \\
\hline $\mathrm{Ce}$ & ppm & 45.39 & 35.38 & 38.43 & 61.99 & 69.47 & 40.70 & 43.96 & 12.97 & 23.84 & 23.69 & 33.65 & 7.80 & 30.46 \\
\hline Pr & ppm & 5.68 & 4.48 & 4.88 & 7.73 & 8.21 & 5.04 & 5.84 & 1.64 & 3.02 & 3.04 & 4.47 & 0.95 & 3.95 \\
\hline Nd & ppm & 21.42 & 16.92 & 18.42 & 28.92 & 29.92 & 18.97 & 22.91 & 6.14 & 11.63 & 11.64 & 17.55 & 3.54 & 15.05 \\
\hline Sm & ppm & 4.52 & 3.61 & 3.91 & 5.74 & 5.64 & 4.17 & 4.76 & 1.26 & 2.87 & 3.07 & 4.02 & 0.91 & 3.93 \\
\hline $\mathbf{E u}$ & ppm & 0.58 & 0.47 & 0.43 & 0.64 & 0.87 & 0.63 & 0.52 & 0.31 & 0.33 & 0.35 & 0.43 & 0.19 & 0.43 \\
\hline Gd & ppm & 3.06 & 2.48 & 2.54 & 3.49 & 3.56 & 2.96 & 2.94 & 0.90 & 2.15 & 2.38 & 2.61 & 0.66 & 2.98 \\
\hline Tb & ppm & 0.39 & 0.33 & 0.31 & 0.41 & 0.41 & 0.38 & 0.37 & 0.13 & 0.30 & 0.35 & 0.34 & 0.10 & 0.40 \\
\hline Dy & ppm & 1.84 & 1.60 & 1.41 & 1.76 & 1.74 & 1.75 & 1.67 & 0.74 & 1.43 & 1.71 & 1.59 & 0.53 & 1.85 \\
\hline Ho & ppm & 0.29 & 0.25 & 0.21 & 0.26 & 0.27 & 0.26 & 0.27 & 0.13 & 0.22 & 0.27 & 0.24 & 0.09 & 0.27 \\
\hline $\mathbf{E r}$ & ppm & 0.68 & 0.58 & 0.52 & 0.63 & 0.64 & 0.59 & 0.63 & 0.35 & 0.48 & 0.59 & 0.54 & 0.21 & 0.56 \\
\hline $\mathbf{T m}$ & ppm & 0.09 & 0.08 & 0.07 & 0.09 & 0.08 & 0.08 & 0.08 & 0.05 & 0.06 & 0.08 & 0.07 & 0.03 & 0.07 \\
\hline $\mathbf{Y b}$ & ppm & 0.59 & 0.54 & 0.50 & 0.63 & 0.51 & 0.51 & 0.57 & 0.37 & 0.40 & 0.50 & 0.43 & 0.22 & 0.42 \\
\hline
\end{tabular}




\begin{tabular}{|c|c|c|c|c|c|c|c|c|c|c|c|c|c|c|}
\hline $\mathbf{L u}$ & ppm & 0.09 & 0.08 & 0.07 & 0.10 & 0.08 & 0.07 & 0.08 & 0.05 & 0.05 & 0.07 & 0.06 & 0.03 & 0.06 \\
\hline A/NK & & 1.38 & 1.42 & 1.35 & 1.37 & 1.47 & 1.45 & 1.43 & 1.37 & 1.38 & 1.40 & 1.36 & 1.46 & 1.36 \\
\hline
\end{tabular}

\begin{tabular}{|c|c|c|c|c|c|c|c|c|c|c|c|c|c|}
\hline Sample & & $\begin{array}{c}\text { PONT } \\
-17 \\
\end{array}$ & $\begin{array}{c}\text { PONT- } \\
18 \\
\end{array}$ & $\begin{array}{c}\text { PONT- } \\
25 \\
\end{array}$ & $\begin{array}{c}\text { PONT- } \\
26 \\
\end{array}$ & $\begin{array}{c}\text { PONT- } \\
27 \\
\end{array}$ & $\begin{array}{c}\text { PONT- } \\
28 \\
\end{array}$ & $\begin{array}{c}\text { PONT } \\
-20 \\
\end{array}$ & $\begin{array}{c}\text { PONT } \\
-21 \\
\end{array}$ & $\begin{array}{c}\text { PONT } \\
-22 \\
\end{array}$ & $\begin{array}{c}\text { PONT } \\
-24 \\
\end{array}$ & $\begin{array}{c}\text { PONT- } \\
7 \\
\end{array}$ & $\begin{array}{c}\text { PONT- } \\
23 \\
\end{array}$ \\
\hline Facies & & \multicolumn{6}{|c|}{ Equigranular leucogranite } & \multicolumn{2}{|c|}{ Late equ. Ig } & \multicolumn{2}{|c|}{ Monzogranite } & \multicolumn{2}{|c|}{$\begin{array}{c}\text { Quartz } \\
\text { monzodiorite }\end{array}$} \\
\hline $\mathrm{SiO}_{2}$ & Wt.\% & 72.84 & 71.07 & 70.36 & 71.40 & 71.72 & 73.04 & 72.32 & 74.86 & 66.12 & 70.29 & 55.00 & 57.18 \\
\hline $\mathbf{A l}_{2} \mathbf{O}_{3}$ & Wt.\% & 15.06 & 15.40 & 15.18 & 14.75 & 15.52 & 14.56 & 15.07 & 14.51 & 16.26 & 15.44 & 16.97 & 17.03 \\
\hline $\mathrm{Fe}_{2} \mathrm{O}_{3}$ & Wt.\% & 1.57 & 1.75 & 2.04 & 1.35 & 1.38 & 1.37 & 1.21 & 0.81 & 4.24 & 1.98 & 8.31 & 5.93 \\
\hline MnO & Wt.\% & 0.02 & 0.01 & 0.02 & 0.02 & 0.01 & 0.01 & 0.02 & 0.02 & 0.04 & 0.02 & 0.12 & 0.09 \\
\hline MgO & Wt.\% & 0.45 & 0.51 & 0.79 & 0.39 & 0.43 & 0.40 & 0.34 & 0.12 & 1.52 & 0.85 & 3.98 & 4.08 \\
\hline $\mathrm{CaO}$ & Wt.\% & 0.69 & 0.79 & 0.84 & 0.63 & 0.57 & 0.57 & 0.68 & 0.38 & 2.24 & 1.61 & 6.14 & 6.05 \\
\hline $\mathrm{Na}_{2} \mathrm{O}$ & Wt. \% & 3.38 & 2.97 & 3.26 & 3.33 & 2.95 & 2.92 & 3.29 & 3.77 & 3.50 & 3.40 & 2.83 & 3.19 \\
\hline $\mathrm{K}_{2} \mathrm{O}$ & Wt. \% & 4.80 & 5.03 & 5.02 & 5.01 & 5.58 & 5.18 & 4.83 & 4.28 & 4.37 & 4.86 & 2.70 & 3.62 \\
\hline $\mathrm{TiO}_{2}$ & Wt.\% & 0.24 & 0.32 & 0.38 & 0.21 & 0.24 & 0.21 & 0.22 & 0.08 & 0.69 & 0.36 & 1.39 & 1.11 \\
\hline $\mathbf{P}_{2} \mathbf{O}_{5}$ & Wt.\% & 0.39 & 0.45 & 0.30 & 0.41 & 0.49 & 0.37 & 0.24 & 0.39 & 0.27 & 0.20 & 0.40 & 0.45 \\
\hline LOI & Wt.\% & 1.05 & 1.50 & 1.35 & 1.15 & 1.55 & 1.31 & 1.67 & 1.19 & 1.09 & 1.06 & 1.24 & 1.20 \\
\hline Total & Wt.\% & 100.5 & 99.80 & 99.53 & 98.64 & 100.4 & 99.95 & 99.87 & 100.4 & 100.3 & 100.1 & 99.07 & 99.94 \\
\hline $\mathbf{L i}$ & ppm & 208 & 100 & 110 & 176 & 145 & 120 & 119 & 168 & 56 & 57 & 72 & 43 \\
\hline Cs & ppm & 25.8 & 5.3 & 10.9 & 15.0 & 15.0 & 13.7 & 21.1 & 22.9 & 5.3 & 3.9 & 5.5 & 4.8 \\
\hline $\mathbf{R b}$ & ppm & 350 & 185 & 306 & 328 & 335 & 266 & 310 & 593 & 178 & 178 & 157 & 129 \\
\hline Sn & ppm & 14.4 & 6.8 & 5.7 & 12.4 & 13.5 & 8.8 & 9.7 & 22.5 & 2.4 & 2.2 & 2.9 & 2.7 \\
\hline W & ppm & 2.43 & 0.57 & 1.16 & 1.32 & 1.86 & 0.83 & 1.19 & 4.38 & 0.39 & 0.31 & 0.55 & 0.69 \\
\hline $\mathbf{B a}$ & ppm & 252 & 373 & 461 & 310 & 327 & 245 & 377 & 21 & 1038 & 1132 & 830 & 1429 \\
\hline $\mathrm{Sr}$ & ppm & 59.3 & 85.5 & 101.3 & 64.7 & 64.9 & 55.1 & 67.2 & 11.4 & 341.7 & 399.1 & 319.3 & 657.5 \\
\hline $\mathrm{Be}$ & ppm & 6.3 & 6.3 & 6.2 & 6.1 & 6.5 & 7.9 & 5.3 & 2.0 & 3.1 & 1.4 & 5.6 & 3.4 \\
\hline $\mathbf{U}$ & ppm & 13.28 & 7.58 & 6.41 & 6.04 & 8.40 & 6.54 & 5.83 & 27.28 & 4.23 & 3.53 & 2.88 & 4.27 \\
\hline Th & ppm & 18.48 & 15.65 & 31.75 & 12.91 & 11.99 & 11.51 & 13.15 & 3.71 & 26.58 & 19.22 & 9.30 & 17.30 \\
\hline $\mathbf{N b}$ & ppm & 6.89 & 6.20 & 3.96 & 6.30 & 7.56 & 5.54 & 6.23 & 9.35 & 9.76 & 4.75 & 10.02 & 14.46 \\
\hline Ta & ppm & 1.33 & 0.68 & 0.45 & 00 & 1.51 & 0.95 & 1.08 & 2.10 & 0.66 & 0.41 & 0.62 & 1.03 \\
\hline $\mathbf{Z r}$ & ppm & 101.0 & 137.6 & 155.1 & 86.0 & 97.2 & 82.3 & 103.3 & 36.7 & 285.5 & 143.6 & 174.7 & 220.5 \\
\hline Hf & ppm & 3.14 & 4.14 & 4.46 & 2.73 & 3.03 & 2.56 & 3.29 & 1.66 & 7.20 & 4.14 & 4.41 & 5.31 \\
\hline $\mathbf{B i}$ & ppm & 0.89 & 0.32 & 0.25 & 0.66 & 0.77 & 0.47 & 0.60 & 1.28 & bld & bld & bld & 0.13 \\
\hline Cd & ppm & 0.19 & 0.20 & 0.19 & 0.14 & 0.14 & 0.17 & bld & 0.19 & 0.31 & 0.13 & 0.24 & 0.24 \\
\hline Co & ppm & 1.48 & 1.45 & 3.09 & 1.30 & 1.12 & 1.14 & 1.46 & 0.43 & 7.539 & 3.268 & 18.92 & 16.72 \\
\hline $\mathrm{Cr}$ & ppm & 19.18 & 21.46 & 28.97 & 16.98 & 11.25 & 7.89 & 9.505 & 7.339 & 38.66 & 16.38 & 156.6 & 110.8 \\
\hline $\mathrm{Cu}$ & ppm & bld & bld & 6.12 & bld & 6.39 & bld & bld & bld & 12.77 & bld & 6.49 & 12.39 \\
\hline $\mathbf{G a}$ & ppm & 24.8 & 23.3 & 25.9 & 24.0 & 23.3 & 21.7 & 26.5 & 31.8 & 25.6 & 22.5 & 22.8 & 21.6 \\
\hline $\mathbf{G e}$ & ppm & 1.65 & 1.35 & 1.33 & 1.51 & 1.59 & 1.34 & 1.48 & 2.13 & 1.35 & 1.15 & 1.61 & 1.53 \\
\hline In & ppm & 0.097 & bld & 0.072 & 0.1 & 0.113 & 0.087 & bld & 0.178 & bld & bld & 0.098 & 0.08 \\
\hline Mo & ppm & bld & bld & bld & bld & bld & bld & bld & bld & bld & bld & bld & 0.779 \\
\hline $\mathrm{Ni}$ & ppm & bld & bld & 7.174 & bld & bld & bld & bld & bld & 13.87 & 6.076 & 5.926 & 20.78 \\
\hline $\mathbf{P b}$ & ppm & 24.8 & 35.2 & 27.9 & 28.1 & 32.8 & 29.4 & 25.9 & 8.2 & 36.3 & 40.8 & 13.9 & 25.4 \\
\hline Sc & ppm & 3.68 & 3.16 & 3.91 & 2.22 & 2.4 & 2 & 2.58 & 3.95 & 9.87 & 4.32 & 22.79 & 19.4 \\
\hline Sb & ppm & bld & bld & bld & bld & bld & bld & bld & bld & bld & bld & bld & 0.35 \\
\hline $\mathbf{V}$ & ppm & 12.8 & 12.5 & 27.1 & 8.2 & 9.4 & 7.4 & 10.7 & 1.9 & 50.0 & 27.7 & 132.1 & 121.7 \\
\hline $\mathbf{Y}$ & ppm & 8.20 & 12.69 & 8.95 & 7.48 & 9.04 & 7.79 & 6.37 & 6.39 & 20.85 & 8.47 & 20.03 & 21.64 \\
\hline Zn & ppm & 91.08 & 41.72 & 97.25 & 87.6 & 72.71 & 83.44 & 94.1 & 86.51 & 98.36 & 60.17 & 102 & 78.58 \\
\hline As & ppm & bld & bld & 10.21 & 1.528 & 2.292 & 3.15 & 2.292 & 10.71 & bld & bld & bld & 4.085 \\
\hline $\mathbf{L a}$ & ppm & 19.88 & 27.43 & 34.10 & 18.47 & 19.08 & 16.63 & 23.44 & 4.39 & 65.52 & 43.98 & 22.54 & 53.80 \\
\hline $\mathrm{Ce}$ & ppm & 45.63 & 59.93 & 77.97 & 41.16 & 42.10 & 37.50 & 46.61 & 10.35 & 131.8 & 84.05 & 50.60 & 104.70 \\
\hline Pr & ppm & 6.05 & 7.74 & 10.39 & 5.36 & 5.45 & 4.88 & 5.56 & 1.41 & 15.34 & 9.79 & 7.56 & 12.34 \\
\hline Nd & ppm & 23.97 & 30.26 & 40.82 & 20.86 & 20.91 & 18.85 & 20.32 & 5.39 & 56.70 & 34.99 & 33.32 & 46.18 \\
\hline Sm & ppm & 5.15 & 7.57 & 7.88 & 5.03 & 5.25 & 4.76 & 4.31 & 1.57 & 10.44 & 5.95 & 6.85 & 8.10 \\
\hline $\mathbf{E u}$ & ppm & 0.48 & 0.77 & 0.81 & 0.58 & 0.59 & 0.51 & 0.65 & 0.04 & 1.68 & 1.35 & 1.70 & 1.96 \\
\hline Gd & ppm & 3.20 & 5.64 & 4.42 & 3.45 & 3.87 & 3.36 & 2.86 & 1.21 & 6.89 & 3.64 & 4.96 & 5.81 \\
\hline $\mathbf{T b}$ & ppm & 0.41 & 0.75 & 0.49 & 0.44 & 0.53 & 0.44 & 0.36 & 0.21 & 0.88 & 0.42 & 0.71 & 0.78 \\
\hline
\end{tabular}




\begin{tabular}{|c|c|c|c|c|c|c|c|c|c|c|c|c|c|}
\hline Dy & ppm & 1.88 & 3.22 & 2.15 & 1.89 & 2.34 & 1.94 & 1.59 & 1.20 & 4.42 & 1.99 & 3.98 & 4.34 \\
\hline Ho & ppm & 0.29 & 0.44 & 0.33 & 0.27 & 0.32 & 0.27 & 0.23 & 0.21 & 0.82 & 0.32 & 0.79 & 0.84 \\
\hline $\mathbf{E r}$ & ppm & 0.67 & 0.92 & 0.79 & 0.55 & 0.63 & 0.55 & 0.51 & 0.54 & 2.03 & 0.79 & 1.99 & 2.16 \\
\hline $\mathbf{T m}$ & ppm & 0.09 & 0.11 & 0.10 & 0.06 & 0.07 & 0.06 & 0.07 & 0.09 & 0.27 & 0.10 & 0.27 & 0.30 \\
\hline $\mathbf{Y b}$ & ppm & 0.56 & 0.67 & 0.66 & 0.40 & 0.46 & 0.38 & 0.41 & 0.56 & 1.78 & 0.65 & 1.77 & 1.98 \\
\hline $\mathbf{L u}$ & ppm & 0.08 & 0.09 & 0.10 & 0.05 & 0.06 & 0.05 & 0.06 & 0.08 & 0.27 & 0.10 & 0.26 & 0.30 \\
\hline A/NK & & 1.40 & 1.49 & 1.40 & 1.35 & 1.42 & 1.40 & 1.41 & 1.34 & 1.55 & 1.42 & 2.23 & 1.85 \\
\hline A/CNK & & 1.25 & 1.31 & 1.23 & 1.22 & 1.30 & 1.27 & 1.27 & 1.26 & 1.12 & 1.12 & 0.90 & 0.84 \\
\hline
\end{tabular}

Late equ. Lg: late eqigranular leucogranite; bdl: below detection limit; LOI: loss on ignition 
Table 3

\begin{tabular}{|c|c|c|c|c|c|c|c|c|c|c|c|c|c|c|c|}
\hline $\begin{array}{l}\text { Sampl } \\
\text { e }\end{array}$ & $\begin{array}{c}\text { Intrusi } \\
\text { on }\end{array}$ & Facies & $\begin{array}{c}\mathbf{R b} \\
(\mathbf{p p m})\end{array}$ & $\begin{array}{c}\text { Sr } \\
(\mathbf{p p m})\end{array}$ & $\begin{array}{l}{ }^{87} \mathbf{R b} /{ }^{8} \\
{ }^{6} \mathrm{Sr}\end{array}$ & $\begin{array}{c}{ }^{87} \mathrm{Sr} /{ }^{86} \\
\mathrm{Sr}\end{array}$ & \pm & $\begin{array}{c}{ }^{87} \mathrm{Sr} /{ }^{86} \\
\mathrm{Sr} \\
(315 \\
\mathrm{Ma}) \\
\end{array}$ & $\underset{(\mathbf{p p m})}{\mathrm{Sm}}$ & $\begin{array}{c}\text { Nd } \\
(\mathbf{p p m})\end{array}$ & ${ }^{147} \mathbf{S m} /{ }^{14}$ & ${ }^{143} \mathrm{Nd} /{ }^{14}$ & \pm & $\begin{array}{l}\text { ENd } \\
\text { (315 } \\
\text { Ma) }\end{array}$ & $\begin{array}{c}\mathbf{T} \\
\text { DM}^{*}\end{array}$ \\
\hline $\begin{array}{c}\text { PONT } \\
-3\end{array}$ & Pontivy & $\begin{array}{l}\text { Equigranula } \\
\text { r lg }\end{array}$ & 260.6 & 78.8 & 9.61 & $\begin{array}{c}0.750 \\
650\end{array}$ & $\begin{array}{l}1 \\
0\end{array}$ & $\begin{array}{c}0.7075 \\
47\end{array}$ & 3.8 & 18.4 & $\begin{array}{c}0.12563 \\
7\end{array}$ & $\begin{array}{c}0.51232 \\
2\end{array}$ & 5 & -3.30 & $\begin{array}{c}1.2 \\
9\end{array}$ \\
\hline $\begin{array}{c}\text { PONT } \\
-6\end{array}$ & Pontivy & $\begin{array}{l}\text { Equigranula } \\
\text { r lg }\end{array}$ & 301.1 & 63.4 & 13.83 & $\begin{array}{c}0.771 \\
012\end{array}$ & $\begin{array}{l}1 \\
1\end{array}$ & $\begin{array}{c}0.7090 \\
21\end{array}$ & 4.6 & 22.8 & $\begin{array}{c}0.12110 \\
4\end{array}$ & $\begin{array}{c}0.51225 \\
6\end{array}$ & 5 & -4.42 & $\begin{array}{c}1.3 \\
8\end{array}$ \\
\hline $\begin{array}{l}\text { PONT } \\
-10\end{array}$ & Pontivy & $\begin{array}{l}\text { Equigranula } \\
\text { r lg }\end{array}$ & 379.6 & 41.5 & 26.76 & $\begin{array}{l}0.825 \\
829\end{array}$ & $\begin{array}{l}1 \\
0\end{array}$ & $\begin{array}{c}0.7058 \\
45\end{array}$ & 2.8 & 11.8 & $\begin{array}{c}0.14353 \\
8\end{array}$ & $\begin{array}{c}0.51233 \\
7\end{array}$ & 4 & -3.73 & $\begin{array}{c}1.3 \\
3\end{array}$ \\
\hline $\begin{array}{l}\text { PONT } \\
-14\end{array}$ & Pontivy & $\begin{array}{l}\text { Equigranula } \\
\text { r lg }\end{array}$ & 372.1 & 32.9 & 33.20 & $\begin{array}{c}0.850 \\
024\end{array}$ & $\begin{array}{l}1 \\
2\end{array}$ & $\begin{array}{c}0.7011 \\
94\end{array}$ & 0.8 & & $\begin{array}{c}0.14510 \\
9\end{array}$ & $\begin{array}{c}0.51228 \\
6\end{array}$ & 6 & -4.79 & $\begin{array}{c}1.4 \\
1\end{array}$ \\
\hline $\begin{array}{l}\text { PONT } \\
-15\end{array}$ & Pontivy & $\begin{array}{l}\text { Equigranula } \\
\text { r lg }\end{array}$ & 304.7 & 49.4 & 18.00 & $\begin{array}{c}0.790 \\
331\end{array}$ & $\begin{array}{l}1 \\
0\end{array}$ & $\begin{array}{c}0.7096 \\
17\end{array}$ & & 14.7 & $\begin{array}{c}0.15125 \\
4\end{array}$ & $\begin{array}{c}0.51231 \\
0\end{array}$ & 5 & -4.58 & $\begin{array}{c}1.3 \\
9\end{array}$ \\
\hline $\begin{array}{c}\text { PONT } \\
-26\end{array}$ & Pontivy & $\begin{array}{l}\text { Equigranula } \\
\text { r lg }\end{array}$ & 327.7 & 64.7 & 14.74 & $\begin{array}{c}0.774 \\
110\end{array}$ & $\begin{array}{l}1 \\
0\end{array}$ & $\begin{array}{c}0.7080 \\
09\end{array}$ & & & $\begin{array}{c}0.14011 \\
7\end{array}$ & $\begin{array}{c}0.51233 \\
4\end{array}$ & 5 & -3.65 & $\begin{array}{c}1.3 \\
2\end{array}$ \\
\hline $\begin{array}{l}\text { PONT } \\
-20\end{array}$ & $\begin{array}{l}\text { Langon } \\
\text { net }\end{array}$ & Late equ. $\lg$ & 310.3 & 63.6 & 14.18 & $\begin{array}{c}0.763 \\
911\end{array}$ & $\begin{array}{l}1 \\
0\end{array}$ & $\begin{array}{c}0.7003 \\
23\end{array}$ & & 20.9 & $\begin{array}{c}0.12059 \\
3\end{array}$ & $\begin{array}{c}0.51235 \\
5\end{array}$ & 5 & -2.46 & $\begin{array}{c}1.2 \\
3\end{array}$ \\
\hline $\begin{array}{l}\text { PONT } \\
-21\end{array}$ & $\begin{array}{c}\text { Langon } \\
\text { net }\end{array}$ & Late equ. lg & 593.2 & 11.7 & $\begin{array}{c}155.3 \\
8\end{array}$ & $\begin{array}{l}1.308 \\
011\end{array}$ & $\begin{array}{l}1 \\
3\end{array}$ & $\begin{array}{c}0.6114 \\
38\end{array}$ & 1.5 & 5.6 & $\begin{array}{c}0.16293 \\
7\end{array}$ & $\begin{array}{c}0.51236 \\
3\end{array}$ & 5 & -4.00 & $\begin{array}{c}1.3 \\
5\end{array}$ \\
\hline $\begin{array}{l}\text { PONT } \\
-22\end{array}$ & $\begin{array}{l}\text { Rostren } \\
\text { en }\end{array}$ & $\begin{array}{l}\text { Monzograni } \\
\text { te }\end{array}$ & 178.4 & 320.2 & 1.61 & $\begin{array}{c}0.713 \\
663\end{array}$ & $\begin{array}{l}1 \\
1\end{array}$ & $\begin{array}{c}0.7064 \\
31\end{array}$ & 9.8 & 56.0 & $\begin{array}{c}0.11727 \\
1\end{array}$ & $\begin{array}{c}0.51231 \\
1\end{array}$ & 5 & -3.19 & $\begin{array}{c}1.2 \\
8\end{array}$ \\
\hline $\begin{array}{l}\text { PONT } \\
-24\end{array}$ & $\begin{array}{l}\text { Rostren } \\
\text { en }\end{array}$ & $\begin{array}{l}\text { Monzograni } \\
\text { te }\end{array}$ & 177.6 & 374.7 & 1.37 & $\begin{array}{c}0.712 \\
872\end{array}$ & 1 & $\begin{array}{c}0.7067 \\
22\end{array}$ & 5.6 & 34.7 & $\begin{array}{c}0.10890 \\
0\end{array}$ & $\begin{array}{c}0.51234 \\
6\end{array}$ & 4 & -2.17 & $\begin{array}{c}1.2 \\
0\end{array}$ \\
\hline $\begin{array}{c}\text { PONT } \\
-7\end{array}$ & Pontivy & $\begin{array}{c}\text { Qtz } \\
\text { monzodiorit } \\
\mathrm{e} \\
\end{array}$ & 157.3 & 303.6 & 1.50 & $\begin{array}{c}0.712 \\
591 \\
\end{array}$ & $\begin{array}{l}1 \\
0\end{array}$ & $\begin{array}{c}0.7058 \\
68\end{array}$ & 6.6 & 33.9 & $\begin{array}{c}0.11760 \\
0\end{array}$ & $\begin{array}{c}0.51233 \\
5\end{array}$ & 2 & -2.73 & $\begin{array}{c}1.2 \\
5\end{array}$ \\
\hline $\begin{array}{l}\text { QIMP } \\
-1\end{array}$ & Moelan & $\begin{array}{l}\text { Metagranito } \\
\text { id }\end{array}$ & & & & & & & 3.9 & 16.5 & $\begin{array}{c}0.14334 \\
4\end{array}$ & $\begin{array}{c}0.51254 \\
8\end{array}$ & 4 & 0.39 & $\begin{array}{c}1.0 \\
0\end{array}$ \\
\hline PLG-1 & $\begin{array}{l}\text { Plougue } \\
\text { nast }\end{array}$ & $\begin{array}{l}\text { Metagranito } \\
\text { id }\end{array}$ & & & & & & & 3.8 & 17.0 & $\begin{array}{c}0.13494 \\
2\end{array}$ & $\begin{array}{c}0.51249 \\
8\end{array}$ & 4 & -0.25 & $\begin{array}{c}1.0 \\
5\end{array}$ \\
\hline PLG-2 & $\begin{array}{l}\text { Plougue } \\
\text { nast }\end{array}$ & $\begin{array}{l}\text { Metagranito } \\
\text { id }\end{array}$ & & & & & & & 5.4 & 28.5 & $\begin{array}{c}0.11395 \\
6\end{array}$ & $\begin{array}{c}0.51232 \\
3\end{array}$ & 5 & -2.81 & $\begin{array}{c}1.2 \\
5\end{array}$ \\
\hline PLG-3 & $\begin{array}{l}\text { Plougue } \\
\text { nast }\end{array}$ & $\begin{array}{l}\text { Metagranito } \\
\text { id }\end{array}$ & & & & & & & 2.5 & 9.9 & $\begin{array}{c}0.15484 \\
1\end{array}$ & $\begin{array}{c}0.51240 \\
7\end{array}$ & 5 & -2.83 & $\begin{array}{c}1.2 \\
6\end{array}$ \\
\hline PLG-4 & $\begin{array}{c}\text { Plougue } \\
\text { nast }\end{array}$ & $\begin{array}{l}\text { Metagranito } \\
\text { id } \\
\end{array}$ & & & & & & & 1.6 & 6.9 & $\begin{array}{c}0.14189 \\
4\end{array}$ & $\begin{array}{c}0.51255 \\
3 \\
\end{array}$ & 5 & 0.54 & $\begin{array}{c}0.9 \\
9 \\
\end{array}$ \\
\hline
\end{tabular}

* Two stages $T_{D M}$ calculated using the equation of Liew and Hofmann (1988) for an age of $315 \mathrm{Ma}$

Equigranular lg: equigranular leucogranite; late equ. lg: late equigranular leucogranite 


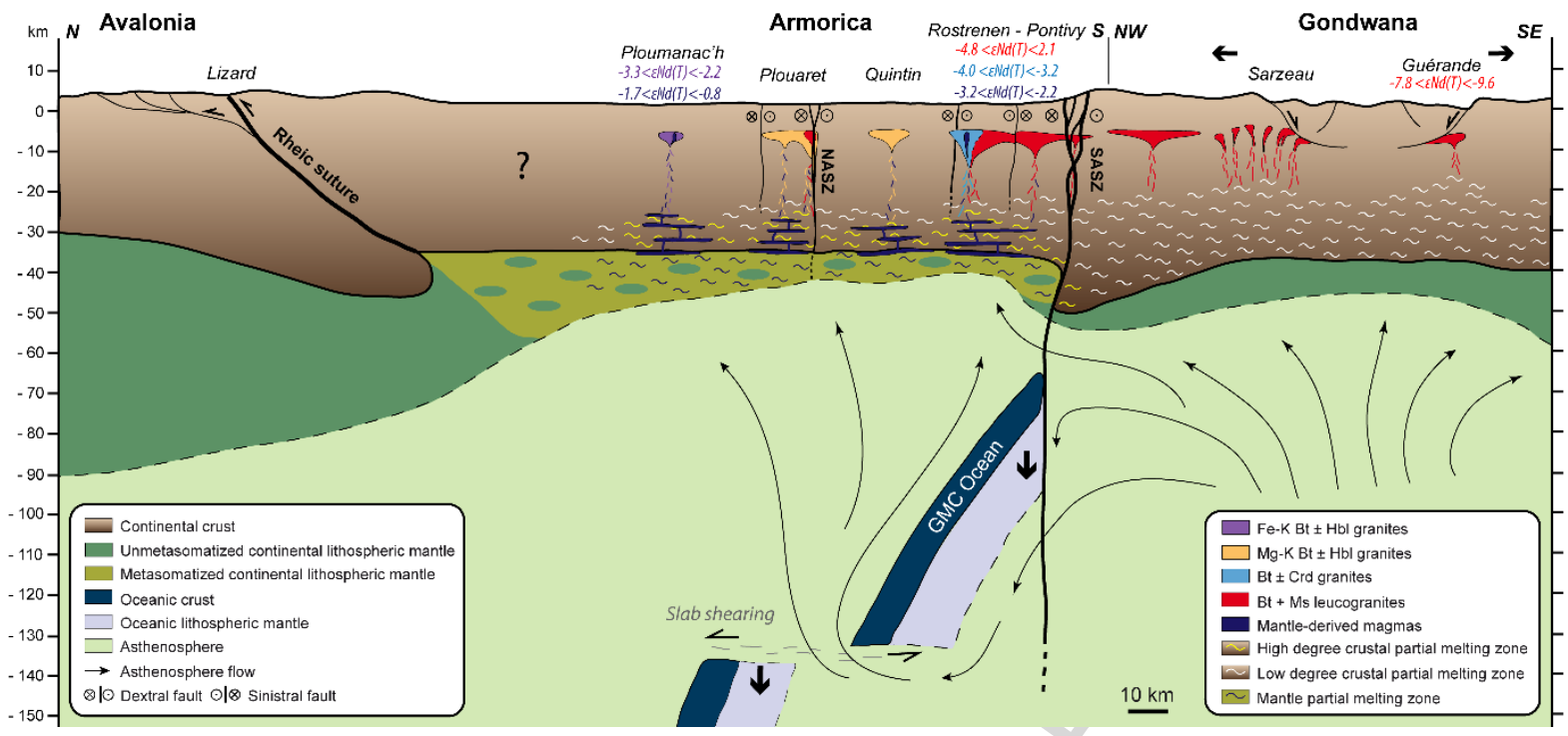

Graphical abstract 


\section{Highlights}

- The Pontivy-Rostrenen intrusion emplaced along a lithospheric wrench fault

- Mantle-derived rocks increase from $\mathrm{S}$ to $\mathrm{N}$ at the expense of crustal leucogranites

- Magmas with crustal and mantellic origins were emplaced synchronously at ca. 315 $\mathrm{Ma}$

- Magmas experienced mineral fractionation, mixing or peritectic mineral entrainment

- Asthenosphere upwelling and melting were triggered by slab tearing during lithospheric wrenching 